ANDRÉ LUIZ BALDIM MARTINS

REUTILIZAÇÃO DE BATERIAS AUTOMOTIVAS

COMO FONTE ALTERNATIVA DE ENERGIA

SÃO PAULO

2015 


\section{REUTILIZAÇÃO DE BATERIAS AUTOMOTIVAS COMO FONTE ALTERNATIVA DE ENERGIA}

Dissertação apresentada à Escola Politécnica da Universidade de São Paulo para a obtenção do título de Mestre em Ciências em Engenharia Elétrica.

Área de Concentração:

Microeletrônica

Orientador: Prof. Dr. Roberto Koji Onmori

\section{SÃO PAULO}

2015 
Este exemplar foi revisado e corrigido em relação à versão original, sob responsabilidade única do autor e com a anuência de seu orientador.

São Paulo, 04 de novembro de 2015.

Assinatura do autor

Assinatura do orientador

Catalogação-na-publicação

Martins, André Luiz Baldim

Reutilização de baterias automotivas como fonte alternativa de energia / A.L.B. Martins. - versão corr - São Paulo, 2015. $112 \mathrm{p}$.

Dissertação (Mestrado) - Escola Politécnica da Universidade de São Paulo. Departamento de Engenharia de Sistemas Eletrônicos.

1.Fontes alternativas de energia 2.Baterias automotivas (Reutilização) I.Universidade de São Paulo. Escola Politécnica. Departamento de Engenharia de Sistemas Eletrônicos II.t. 
Dedico esse trabalho às gerações futuras, que sempre desenvolvam trabalhos sustentáveis em prol de um mundo melhor para se viver. 
"Nossa maior fraqueza está em desistir. O caminho mais certo de vencer é tentar mais uma vez."

Thomas Alva Edison 


\section{Agradecimentos}

Agradeço primeiramente a Deus por presentear-me com sabedoria e perseverança, qualidades sem as quais seria praticamente impossível o meu desenvolvimento humano e profissional.

Agradeço a minha família que colaborou e contribuiu para o sucesso desse trabalho, até mesmo com simples palavras de conforto como "você é inteligente, você vai conseguir" e "depois da tempestade sempre vem o pôr do sol”.

Agradeço aos meus professores que acreditaram no meu potencial e me orientaram até a conclusão do trabalho. 


\section{RESUMO}

Atualmente um dos principais objetivos na área de pesquisa tecnológica é o desenvolvimento de soluções em favor do Meio Ambiente. Este trabalho tem por objetivo demonstrar a reutilização e consequentemente o aumento da vida útil de uma bateria Chumbo-Ácido, comumente instaladas em veículos automóveis, bem como beneficiar locais e usuários remotos onde o investimento na instalação de linhas de transmissão se torna inviável geográfica e economicamente, utilizando a luz solar como fonte de energia.

No entanto a parte mais suscetível a falhas são as próprias baterias, justamente pela vida útil delas serem pequenas (em torno de 3 anos para a bateria automotiva) em comparação com o restante do sistema. Considerando uma unidade que já foi usada anteriormente, a possibilidade de falhas é ainda maior.

A fim de diagnosticar e evitar que uma simples bateria possa prejudicar o funcionamento do sistema como um todo, o projeto considera a geração de energia elétrica por células fotovoltaicas e também contempla um sistema microcontrolado para leitura de dados utilizando o microcontrolador ATmega/Arduino, leitura de corrente por sensores de efeito hall da Allegro Systems, relés nas baterias para abertura e fechamento delas no circuito e um sistema de alerta para o usuário final de qual bateria está em falha e que precisa ser reparada e/ou trocada.

Esse projeto foi montado na Ilha dos Arvoredos - SP, distante da costa continental em aproximadamente 2,0km. Foram instaladas células solares e um banco de baterias, a fim de estudar o comportamento das baterias. $\mathrm{O}$ programa pôde diagnosticar e isolar uma das baterias que estava apresentando defeito, a fim de se evitar que a mesma viesse a prejudicar o sistema como um todo. Por conta da dificuldade de locomoção imposta pela geografia, foi escolhido o cartão SD para o armazenamento dos dados obtidos pelo Arduino. Posteriormente os dados foram compilados e analisados.

A partir dos resultados apresentados podemos concluir que é possível usar baterias novas e baterias usadas em um mesmo sistema, de tal forma que se alguma das baterias apresentar uma falha o sistema por si só isolará a unidade.

Palavras-chave: Baterias. Células Solares. Locais Remotos. Reuso. 


\begin{abstract}
Actually one of the main goals in the technology research area is the development of solutions in accordance with our Environment. The objective of this work is to illustrate the reuse and consequently increase of the Lead-Acid Secondary Battery lifecycle, commonly installed in automotive vehicles, as well as to benefit remote areas and users, where the investment in a new electrical infrastructure is unfavorable geographically and economically, using sunlight as a feasible and available alternative solution.

However, the most fragile part of the system are the batteries, due to their own short service life (approximately 3 years for the automotive battery), compared with the other equipment within the system. The chance to have a failure is even higher when using a unit which has been serviced before.

In order to anticipate and avoid that a single faulty battery could bring the entire system down, the project consider using photovoltaic cells for electricity generation and also has a micro-controlled system for data reading using an ATmega/Arduino microcontroller, current readings using hall-effect sensors from Allegro Systems, relays on the batteries to open and close themselves in the circuit and an alarm system that indicates to the user which battery is faulty as well as needing repair and/or replacement.

This project has been installed in Ilha dos Arvoredos - SP, a small island with approximately $2.0 \mathrm{~km}$ far from the coast. Solar cells and a battery string have been installed in order to study the behavior of the batteries. The programming could diagnose and isolate one of the batteries that has been having a failure, to avoid that this same single battery could cause a major failure on the entire system. Due to the restrictions imposed by the geography, the SD card has been chosen for the data storage obtained by Arduino board. Later on the data has been compiled as well as analyzed.

The obtained data has shown that it is possible using old and new batteries in a same string, as long as the system will isolate the faulty battery if any of the batteries shows a failure.
\end{abstract}

Key Words: Batteries. Solar Cells. Remote Areas. Reuse. 


\section{SUMÁRIO}

1 - OBJETIVO E MOTIVAÇÃO .................................................................. 9

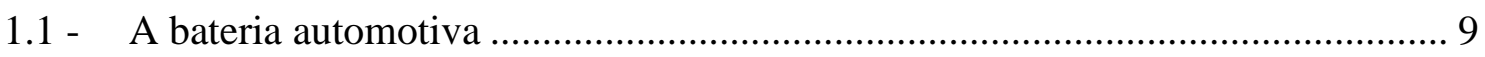

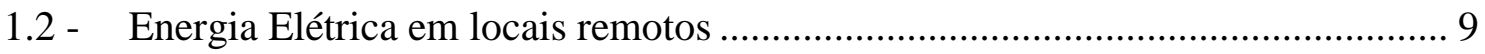

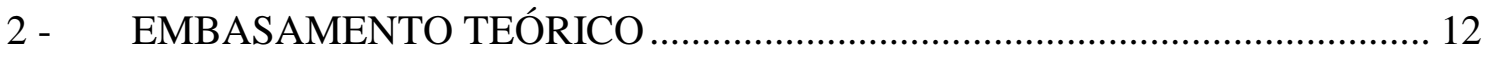

2.1 - A energia elétrica e sua necessidade....................................................... 12

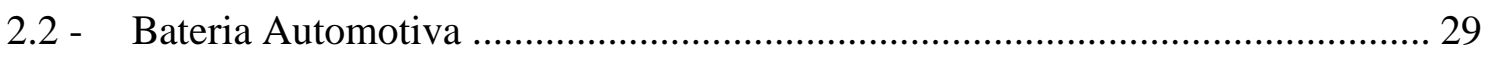

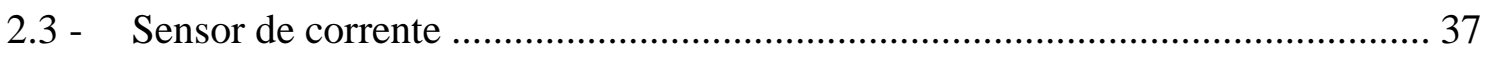

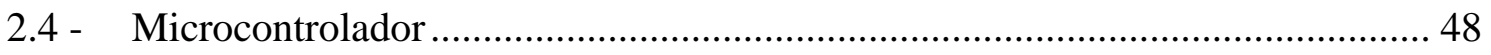

3 - DESENVOLVIMENTO DO PROJETO …................................................... 56

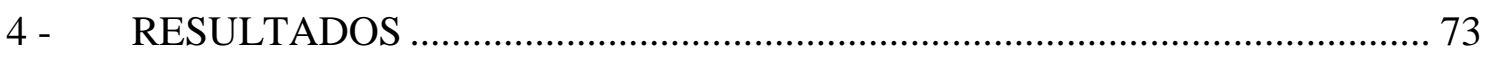

5 - CONCLUSÕES E PLANOS FUTUROS .................................................. 81

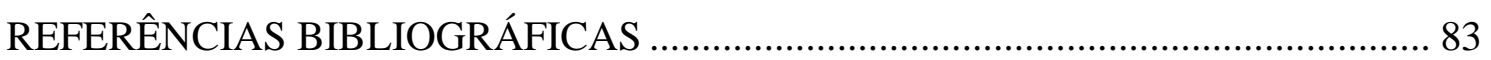

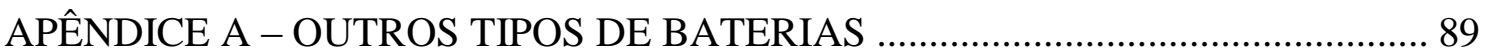

APÊNDICE B - OUTRAS FORMAS DE CARREGAMENTO................................ 90

APÊNDICE C - OUTRAS APLICAÇÕES DO SENSOR HALL ............................... 96 


\section{LISTA DE FIGURAS, GRÁFICOS E TABELAS}

Figura 1.2.1 - Ilha dos Arvoredos - SP 10

Figura 1.2.2 - Células Solares da Estação Espacial Internacional (ISS) ........................ 11

Figura 2.1.1 - Réplica da Pilha de Alessandro Volta................................................. 13

Figura 2.1.2 - Vista em corte de uma pilha de Zinco-Carbono..................................... 15

Figura 2.1.3 - Vista em Corte de uma Pilha Alcalina..................................................... 15

Figura 2.1.4 - Detalhe construtivo da Bateria Chumbo-Ácida ....................................... 16

Gráfico 2.1.5 - Valores de tensão teóricos e reais para diversos tipos de baterias .......... 20

Gráfico 2.1.6 - O Efeito da Temperatura na Descarga da Bateria.................................. 23

Figura 2.1.7 - Pilha Alcalina com Vazamento ........................................................... 27

Gráfico 2.2.1 - Vida útil estimada da bateria, em função da temperatura ....................... 30

Gráfico 2.2.2 - Curvas características do Carregamento por Tensão Constante ............. 33

Gráfico 2.2.3 - Curva VxT para descarga da Bateria ................................................ 35

Figura 2.2.4 - Visão em corte de uma bateria Chumbo-Ácida ..................................... 36

Figura 2.3.1 - Princípio de Funcionamento do Sensor de Efeito Hall ............................ 39

Figura 2.3.2 - Sensor de Efeito Hall para interface com periféricos .............................. 40

Figura 2.3.3 - Característica de um sensor Hall relaciométrico comum ........................ 43

Figura 2.3.4 - Símbolo do Sensor de Efeito Hall em um circuito ................................. 46

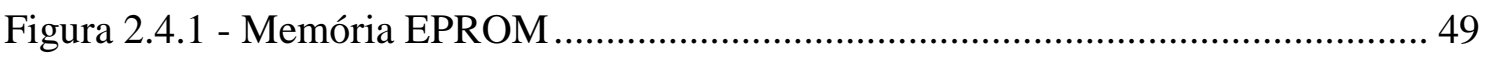

Figura 2.4.2 - Pinagem do microcontrolador ATmega2560 ....................................... 51

Figura 2.4.3 - Diagrama em blocos do Microcontrolador ATmega2560 ...................... 52

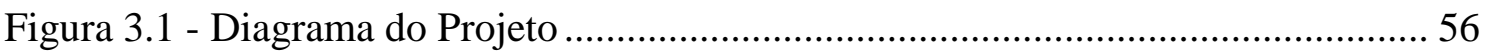

Figura 3.2 - Arduino MEGA 2560 com microcontrolador ATmega2560..................... 57

Diagrama 3.3 - Diagrama Geral Unifilar do Projeto................................................. 59

Figura 3.4 - Baterias com o circuito de Medição ............................................................. 60 
Figura 3.5 - Circuito de Medição da Bateria

Figura 3.6 - Diagrama do Circuito de Medição da Bateria

Figura 3.7 - Diagrama do Projeto com LCD, RTC DS1302, Cartão SD e o Arduino Mega 2560

Figura 3.8 - Projeto com LCD, RTC DS1302, Cartão SD e o Arduino Mega 2560 ...... 63

Figura 3.9 - Diagrama do Circuito Resistivo de Teste.................................................... 66

Figura 3.10 - Circuito Resistivo de Teste, com lâmpadas dicróicas .............................. 67

Figura 3.11 - Exemplo de Arquivo de Saída com as tensões das Baterias.... 68

Figura 3.12 - Exemplo de Arquivo de Saída com medições de Resistência Interna das Baterias 68

Fluxograma 3.13 - Fluxograma de funcionamento quando o sistema estiver carregando as baterias 70

Fluxograma 3.14 - Fluxograma de funcionamento quando o sistema estiver com as baterias alimentando a carga 71

Fluxograma 3.15 - Fluxograma de funcionamento da rotina de Medição da Resistência interna das Baterias 72

Gráfico 4.1 - Teste de Descarregamento das Baterias 73

Gráfico 4.2 - Baterias em Carregamento 74

Gráfico 4.3 - Testes Diários de Resistência Interna (2 ciclos) 75

Gráfico 4.4 - Testes Diários de Resistência Interna (4 vezes ao dia) 75

Gráfico 4.5 - Terminal de leitura de Tensão da Bateria-2 mal conectado 76

Gráfico 4.6 - Somente a Bateria-1 conectada no Barramento 77

Gráfico 4.7 - Somente a Bateria-2 conectada no Barramento 77

Gráfico 4.8 - Bateria-3 apresentando falhas 78

Gráfico 4.9 - Retomada do teste de Resistência Interna 79 
Gráfico 4.10 - Bateria-3 defeituosa, com tensão intermitente

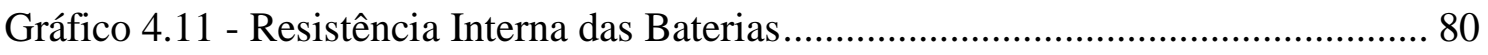

Figura A.1 - Bateria de Íons de Lítio durante a descarga ........................................... 89

Gráfico B.1 - Curvas características do Carregamento por Corrente Constante ............ 90

Tabela B.2 - Fator de correção da tensão, em função da temperatura do Eletrólito........ 92

Gráfico B.3 - Curva Característica do Carregamento por Corrente Decrescente........... 93

Figura C.1 - Sensor de Efeito Hall - Aproximação simples ........................................ 96

Figura C.2 - Sensor de Efeito Hall - Passagem Lateral Unipolar ................................ 97

Figura C.3 - Sensor de Efeito Hall - Passagem Lateral Bipolar .................................. 98

Figura C.4 - Sensor de Efeito Hall - Passagem Lateral Tripolar .................................. 99

Figura C.5 - Sensor de Efeito Hall - Passagem Lateral com dois imãs separados ...... 100

Figura C.6 - Exemplo de Arranjo com Imã Rotativo ............................................... 101

Figura C.7 - Sensor de Efeito Hall - Configuração por Imã Rotativo ......................... 102

Figura C.8 - Sensor de Efeito Hall -Arranjo com Imã Fixo ..................................... 103

Figura C.9 - Sensor de Efeito Hall - Arranjo com Imã Fixo .................................... 103

Figura C.10 - Exemplo de Aplicação na Ignição Automotiva .................................... 107

Figura C.11 - Sensoriamento Magnético de Corrente ................................................. 108

Figura C.12 - Sensor Hall de Corrente com PIC ......................................................... 109 


\section{1 - OBJETIVO E MOTIVAÇÃO}

\section{1 - A bateria automotiva}

A bateria automotiva - como a própria definição já diz - são acumuladores de energia equipados em veículos automotores, responsáveis por auxiliar na partida dos motores à combustão e também para prover energia elétrica à outros sistemas auxiliares como: alarmes, iluminação, som etc.

No entanto essas baterias têm sua vida útil reduzidas quando comparadas às usadas em sistemas estacionários, principalmente por conta do ambiente em que estão instaladas normalmente e também pela forma de carregamento/descarga irregular em que são submetidas. Dessa forma as baterias automotivas tem sua vida útil de aproximadamente 3 anos variando caso-a-caso e, ao final dessa vida útil, a mesma é separada para reciclagem e trocada por uma nova.

Essa bateria considerada inviável para o uso em motores à combustão pode ser usada em outras aplicações que demandam uma menor corrente elétrica.

\section{2 - Energia Elétrica em locais remotos}

Apesar dos avanços tecnológicos que temos a cada dia, ainda se torna inviável geograficamente e economicamente prover energia elétrica para locais remotos. Locais como vilarejos, ilhas e regiões áridas que, apesar de não serem economicamente ativas, não tem um incentivo para o desenvolvimento. Porém podem ser usadas para pesquisas, análises meteorológicas, comunicações etc. que é o caso da Ilha da Moela - SP. Essa ilha fica próxima à cidade do Guarujá, sendo a menor distância 1,2 milhas do continente. Desde o tempo imperial essa ilha vem sendo usada para abrigar um farol 
marítimo (inaugurado em 1830), que auxilia os navegadores a acessarem o Porto de Santos - SP, maior porto brasileiro em operação. Hoje a ilha conta com um farol luminoso de 26 milhas de alcance, um rádio-farol de 300 milhas e também uma estação meteorológica. O abastecimento elétrico é feito por meio de geradores à Diesel, por conta da inviabilidade financeira de se prover energia por linhas de transmissão. Existe também a Ilha de Alcatrazes - SP que é uma das mais distantes da costa paulista, distante a $45 \mathrm{~km}$ do porto de São Sebastião. Hoje a ilha de Alcatrazes é protegida e administrada pelo Instituto Chico Mendes de Conservação à Biodiversidade - ICMBio, autarquia federal.

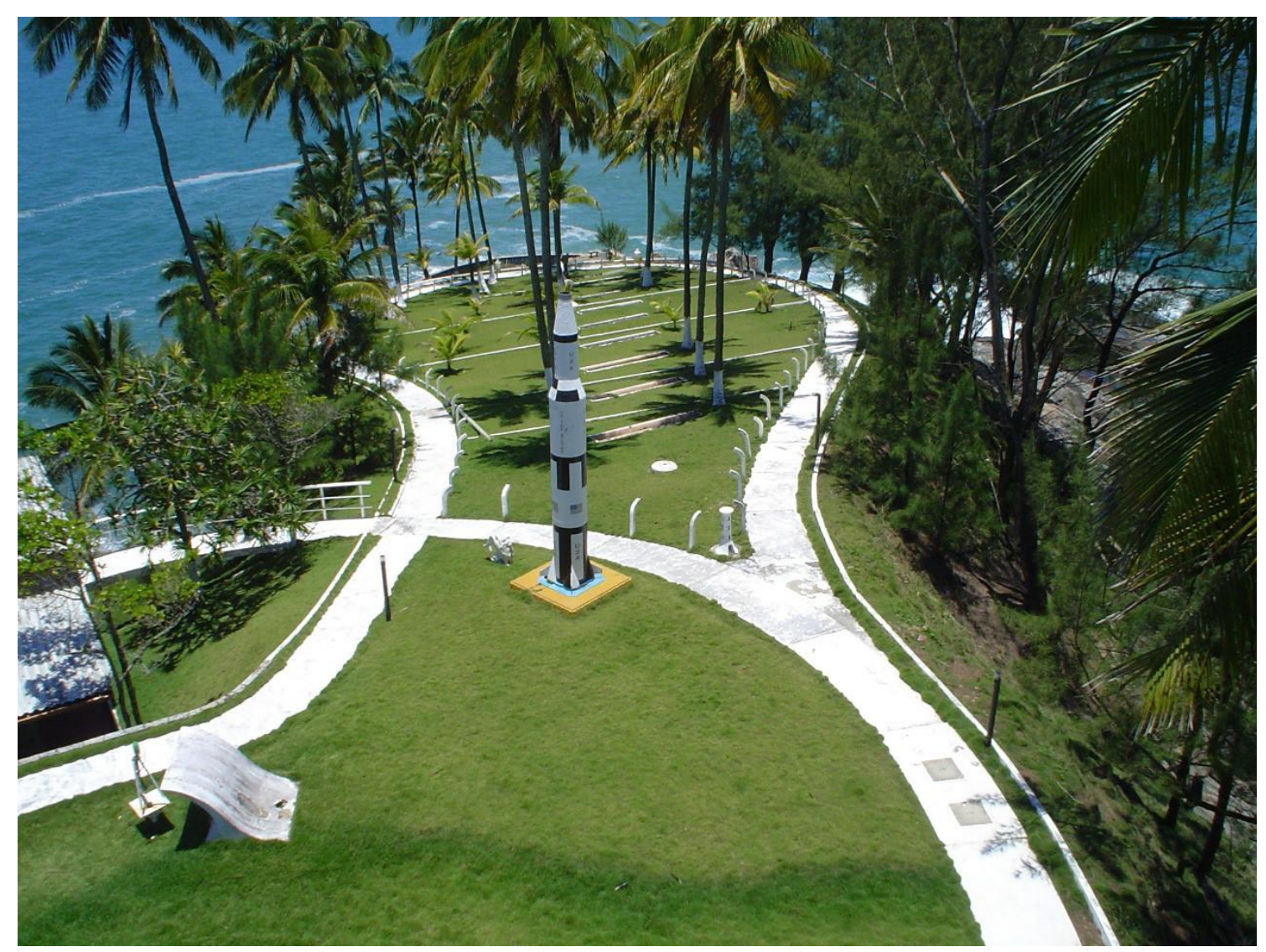

Figura 1.2.1 - Ilha dos Arvoredos - SP

Fonte: Fundação Fernando Lee

Uma situação semelhante à explicada acima é a da Ilha dos Arvoredos - SP, também próximo ao Guarujá em cerca de 2,0km de distância, que também é usada para 
fins de pesquisa nas áreas de geração de energia elétrica por ondas marítimas, células fotovoltaicas, turbinas eólicas, etc. Nessa ilha existem pesquisadores que passam um certo período como habitantes na mesma sem retornar ao continente, de tal forma que a energia elétrica para eles se torna necessário.

Atualmente nas regiões polares são empregados sistemas mistos de geração, utilizando principalmente células solares no período do verão (período de sol) e geradores a Diesel no inverno (período sem sol). No entanto ainda assim existe um grande custo logístico para o transporte de combustível para esse período noturno, bem como manutenções necessárias.

Em satélites artificiais (comunicações, estações espaciais, navegação) que orbitam o nosso planeta foram os pioneiros a utilizarem células solares. Por conta de sua posição na órbita terrestre, a incidência de luz solar sobre as células é de $99 \%$, fazendo com que esse seja o principal meio de fornecimento de energia elétrica no espaço.

Já em regiões tropicais não é necessário o uso de sistemas mistos, podendo ser aplicado o sistema com células solares. Locais em que poderia ser empregada essa tecnologia são as ilhas mencionadas acima, que tem potencial para o desenvolvimento de pesquisas meteorológicas e biológicas.

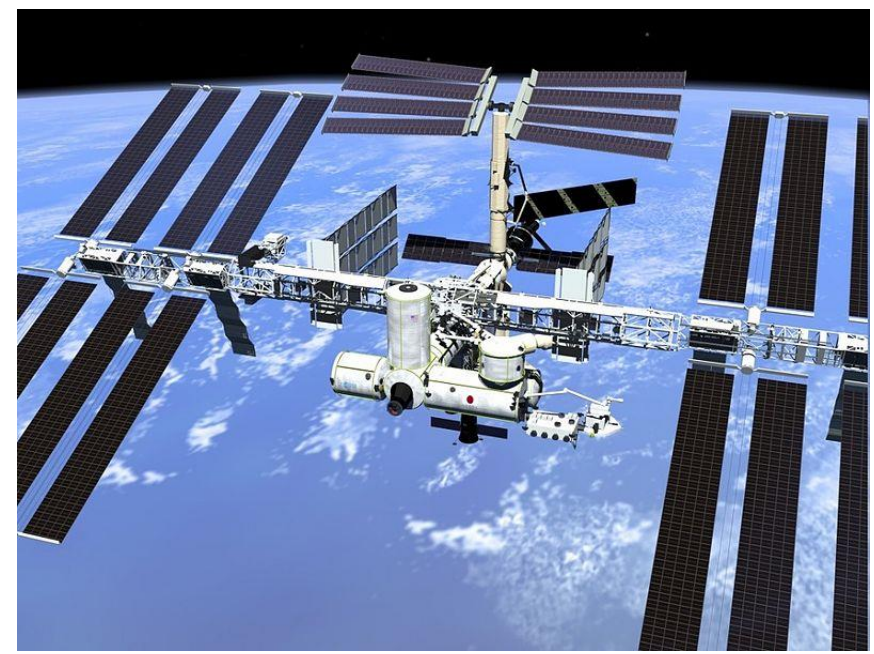

Figura 1.2.2 - Células Solares da Estação Espacial Internacional (ISS) Fonte: Galeria de Imagens da NASA 


\section{2 - EMBASAMENTO TEÓRICO}

\section{1 - A energia elétrica e sua necessidade}

A eletricidade é sem dúvidas uma das maiores necessidades do ser humano atualmente. $\mathrm{O}$ uso da energia elétrica e sua transformação podem ser empregados em diversas necessidades simples do homem:

- Direção e Locomoção - transformando-a em luz;

- $\underline{\text { Alimentação }}$ - transformando-a em energia mecânica, para o processamento de algum alimento, ou ainda movimentando um fluido de gás refrigerante para conservação (no caso uma geladeira);

- Entretenimento - aproveitando-a da forma em que ela se encontra, utilizando em circuitos eletrônicos, para gerar formas coloridas e interagir com o usuário final, em televisores e consoles de videogames, muito comuns nos dias de hoje;

- Comunicação - utilizada em equipamentos de telecomunicações como antenas de transmissão, servidores, telefones celulares e outros.

Observada a partir de fenômenos naturais, o relâmpago é a forma mais primitiva da presença da eletricidade no nosso mundo. Sua manifestação se dá basicamente pela descarga repentina de energia eletrostática armazenada para outro ponto com menor concentração, podendo ser entre as próprias nuvens e/ou entre a nuvem e a superfície terrestre.

Outra forma observada e estudada na Grécia antiga é a energia desferida pelo "peixe-elétrico". Estudiosos da época afirmavam que essa descarga para o corpo humano poderia ser usada como fins terapêuticos para a gota e dor de cabeça, podendo inclusive curá-los. 
Nos dias de hoje a energia elétrica é uma das utilidades praticamente indispensável para o ser humano que vive em centros urbanos. Alguns simples exemplos podem ser citados: aquecimento da água para um banho ou cozinhar; iluminação durante o período noturno; ligar uma televisão para assistir algum programa de entretenimento; carregar a bateria de um celular para fazer ligações para um parente, amigo etc.

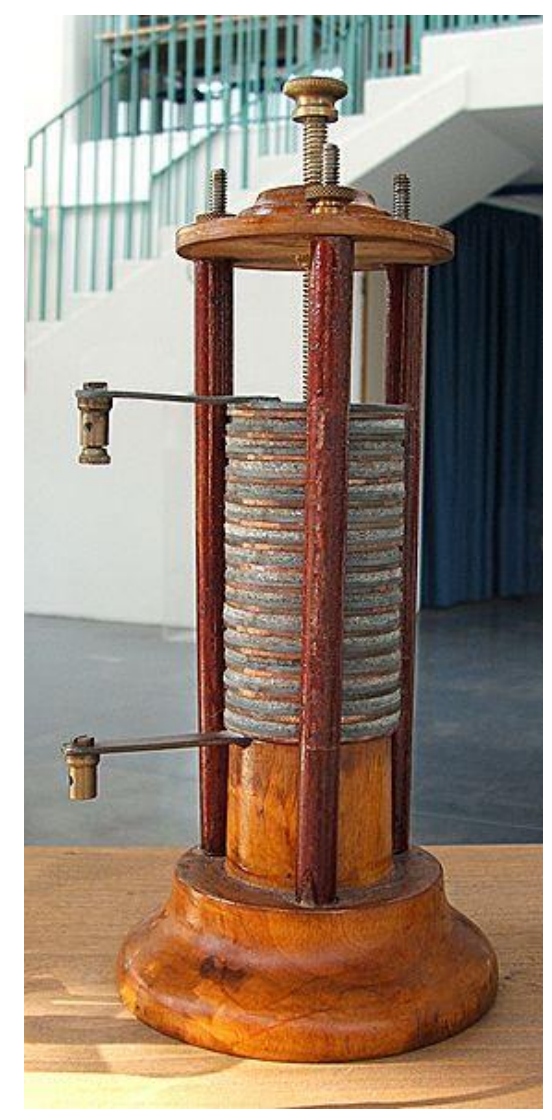

\section{Figura 2.1.1 - Réplica da Pilha de Alessandro Volta \\ Fonte: Electrochemistry Encyclopedia - CWRU}

Uma das descobertas do físico italiano Alessandro Volta no século XVIII foi a possibilidade de se converter energia química (através de uma reação química) em energia elétrica, utilizando-se de lâminas de Zinco $(\mathrm{Zn})$ e Cobre $(\mathrm{Cu})$ e uma solução ácida, criando assim a pilha galvânica. Embora no passado fora utilizada somente para fins medicinais, hoje no século XXI é amplamente empregada em equipamentos eletrônicos (DECKER, 2005). 
A reação química na pilha é a reação de oxidação e redução, ocorrendo no Zinco e no Cobre respectivamente, ambas mergulhadas em uma solução ácida. Isso resulta na criação de íons positivos e negativos, gerando dessa forma uma diferença de potencial nas lâminas.

A partir de então diversas pesquisas foram feitas e diversos materiais foram empregados para o desenvolvimento da "energia portátil". Os materiais empregados e a reação química que ocorre no interior dessa unidade é o que determina o nível de tensão e, dependendo da reação, pode ser revertida ou não. Sendo assim, as baterias são classificadas como Primária e Secundária.

As baterias Primárias - popularmente conhecidas como pilhas - são aquelas em que a reação química não pode ser revertida. São amplamente utilizadas em dispositivos eletrônicos que demandam um baixo fluxo de corrente para funcionar e que se utiliza apenas algumas vezes durante o dia (controles remotos, lanternas, por exemplo). Os materiais empregados comumente são Zinco-Carbono e, nas pilhas alcalinas, Dióxido de Zinco e Manganês. São facilmente encontradas nos mercados com a tensão de $1,5 \mathrm{~V}$. 


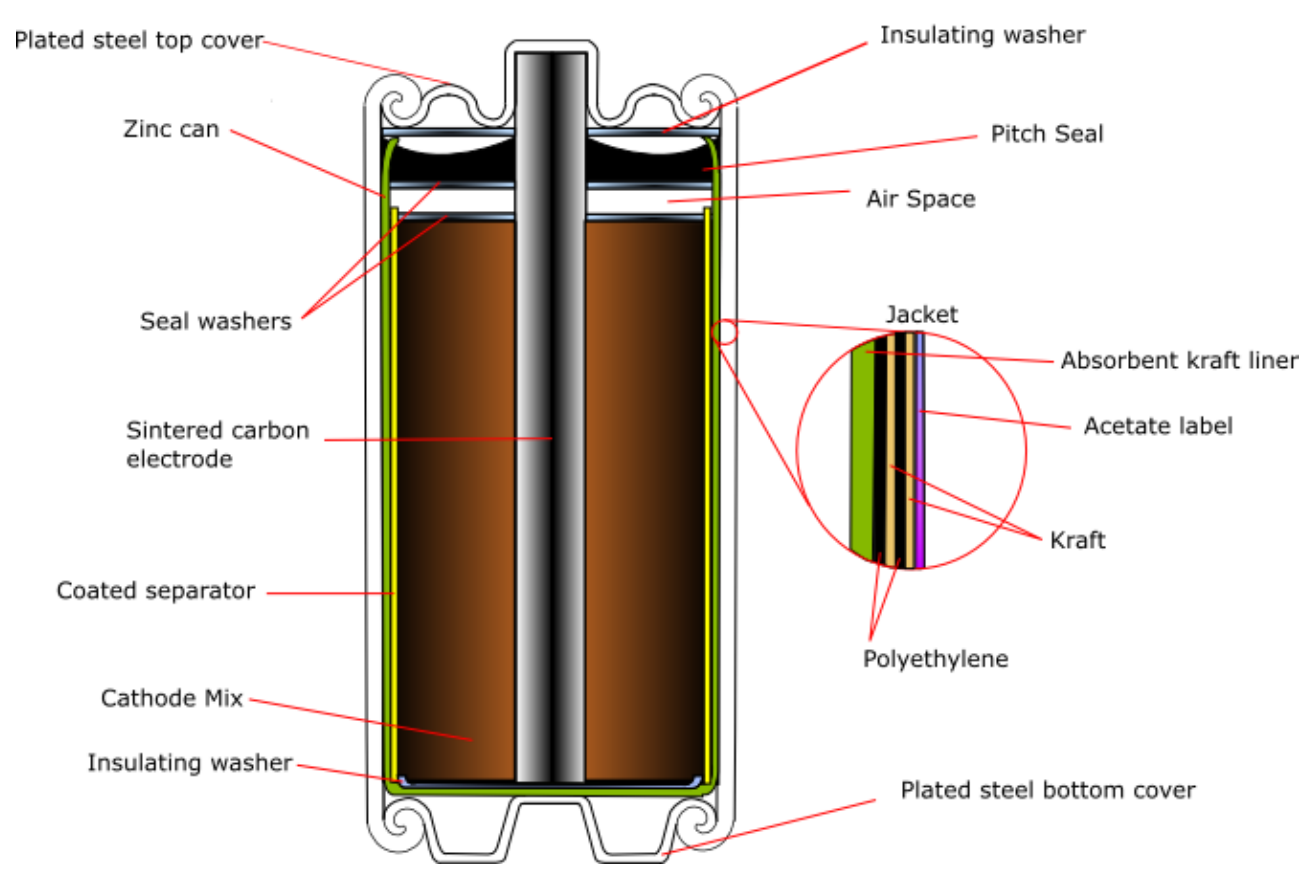

Figura 2.1.2 - Vista em corte de uma pilha de Zinco-Carbono Fonte: DoITPoMS - Universidade de Cambridge - UK

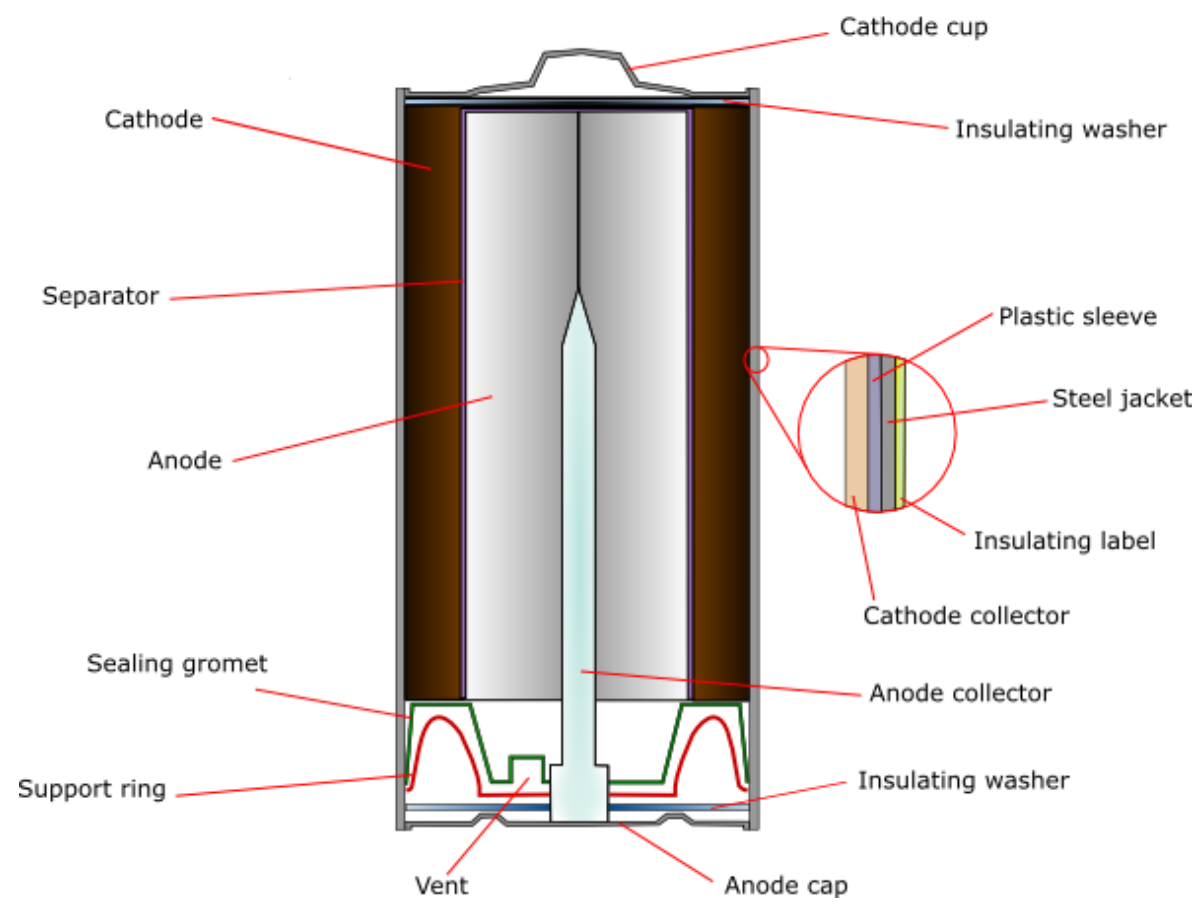

Figura 2.1.3 - Vista em Corte de uma Pilha Alcalina Fonte: DoITPoMS - Universidade de Cambridge - UK

Já as baterias Secundárias - popularmente chamadas de Baterias mesmo - a reação química que gera a diferença de potencial pode ser revertida e restaurada a condição inicial delas. Atualmente é amplamente usada em celulares e laptops, sistemas 
de telecomunicações, iluminação de emergência, sistemas de alarme e monitoramento etc. Os materiais utilizados dependem diretamente da sua aplicação final, variando em função do fluxo de corrente, tensão aplicada, portabilidade, dentre outros fatores.

A bateria chumbo-ácida, inventada em 1859 pelo físico Francês Gaston Planté, é considerada como a primeira bateria recarregável inventada. Apesar de ela ter uma baixa relação energia-peso e também uma baixa relação energia-volume, a bateria chumbo-ácida tem uma grande habilidade de suprir altos níveis de corrente elétrica, o que significa que as células têm a relação potência-peso relativamente alta. Esses benefícios aliado com o baixo custo de produção fizeram com que as tornassem bastantes atrativas no que diz respeito ao uso em veículos automotivos, em especial para a partida do motor de arranque e luzes.

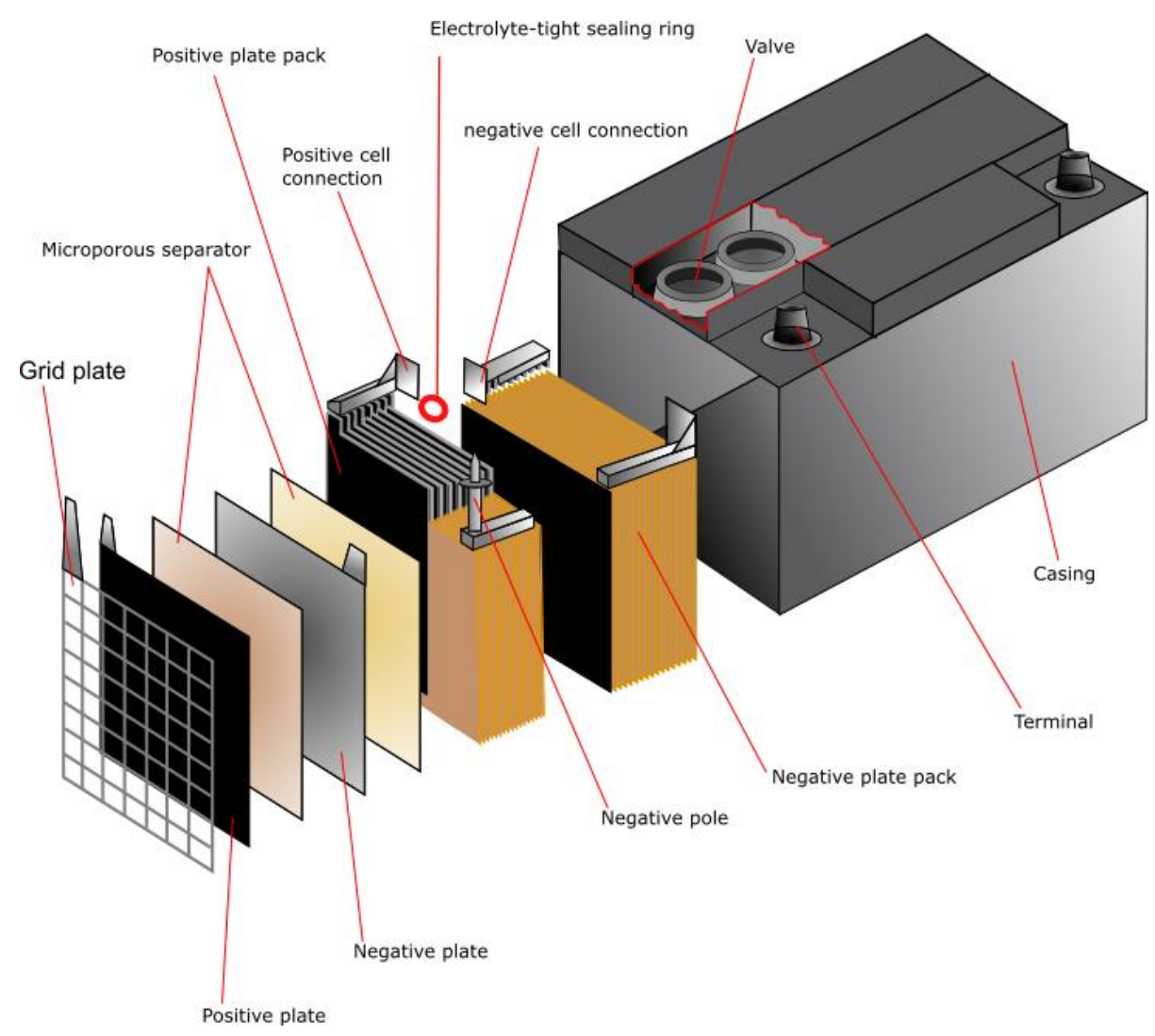

Figura 2.1.4 - Detalhe construtivo da Bateria Chumbo-Ácida Fonte: DoITPoMS - Universidade de Cambridge - UK 
Por conta desse baixo custo apresentado comparado com tecnologias mais novas, as baterias chumbo-ácido são usadas até mesmo onde a corrente demandada não necessariamente precisa ser elevada, podendo alterar assim a construção interna da bateria de tal forma a se obter uma densidade de energia maior. Baterias de grandes dimensões geométricas são amplamente usadas para armazenamento de energia em sistemas de energia ininterrupta (popularmente conhecido por No-Breaks) para salas de servidores e data-centers em geral, torres repetidoras de sinal e antenas, sistemas de comunicação, e em sistemas em que se necessita uma alta disponibilidade como em hospitais por exemplo. Para essas aplicações em específico, as baterias têm uma construção diferenciada a fim de aumentar a capacidade de armazenamento do sistema. A utilização do eletrólito em forma de gel ou ainda um material desenvolvido à base de fibra de vidro que absorve o eletrólito são bastante comuns nessas áreas, simplesmente pela versatilidade de poder empregá-la em outras posições - até mesmo invertidas em alguns casos.

Conforme mencionado anteriormente, as baterias de Chumbo-Ácido são amplamente empregados em veículos automotores e sistemas de telecomunicações, pelo simples fato de se ter uma grande capacidade de descarga e baixo custo de produção. Cada célula produz aproximadamente $2,25 \mathrm{~V}$ e são normalmente encontradas com $12 \mathrm{~V}$ e 24V. A bateria Chumbo-Ácido é construída na tecnologia "úmida", por conta do eletrólito usado $\left(\mathrm{H}_{2} \mathrm{SO}_{4}\right)$ estar em estado líquido. Esse tipo de bateria necessita ser instalada em locais ventilados, por conta da liberação de hidrogênio - gás altamente inflamável - durante um evento de sobrecarga.

No entanto uma nova geração dessa bateria já está em uso, conhecida como VRLA (Valve Regulated Lead-Acid - Chumbo-Ácida, regulada por válvula). A bateria VRLA utiliza o ácido Sulfúrico em forma de gel (reagido com sílica), ou usando um 
material poroso feito de micro-fibra de vidro, preenchido pelo ácido Sulfúrico. Isso torna a bateria mais segura por conta das válvulas manterem a pressão interna nas células, diminuindo assim o risco de explosão;

\section{Qual tipo de bateria então deverá ser escolhido?}

Para responder a essa pergunta, as seguintes características devem ser levadas em conta:

$\checkmark$ Tipo;

$\checkmark$ Tensão;

$\checkmark$ Curva de descarga;

$\checkmark$ Capacidade;

$\checkmark$ Densidade de energia;

$\checkmark$ Densidade específica de energia;

$\checkmark$ Densidade de Potência;

$\checkmark$ Dependência de Temperatura;

$\checkmark$ Tempo de operação;

$\checkmark$ Aspectos físico-construtivos;

$\checkmark$ Ciclo de Carga/Descarga;

$\checkmark$ Ciclo de vida;

$\checkmark$ Custo;

$\checkmark$ Profundidade de descarga;

$\checkmark$ Particularidades da aplicação.

\section{Tipo}

Certifique a necessidade em se usar baterias primárias ou baterias secundárias. 


\section{Tensão}

Conforme detalhado anteriormente, o nível de tensão é um fator relevante em diversos tipos de baterias. A tensão padrão das células das baterias podem ser determinadas a partir da série eletroquímica delas, usando os valores de $\mathrm{E}^{\circ}$.

$$
E^{o}(\text { cátodo })-E^{o}(\hat{a} \text { nodo })=E^{o}(\text { célula })
$$

Essa é a fórmula teórica para cálculo de tensão. A tensão teórica da célula é modificada pela equação de Nernst, o que leva em consideração o comportamento nãopadrão de reação do componente. O potencial de Nernst vai alterar com o tempo por conta do uso ou descarga por atividade (ou concentração), o componente eletro-ativo então assim se altera. Dessa forma a tensão nominal é determinada pela química da célula a qualquer tempo.

A tensão real produzida pela célula vai ser sempre menor comparada com a tensão teórica por conta da polarização e perdas resistivas da bateria, e ainda depende inclusive da carga aplicada à bateria e a impedância interna da célula. Esses fatores dependem da construção do eletrodo e ainda variam em função da temperatura, estado de carga e idade da célula. A tensão atual lida nos terminais da bateria precisa ser suficiente para onde será empregada.

Os valores de tensão então variam de 1,2V para baterias Níquel-Cádmio até 3,7V para baterias de íons de Lítio.

O gráfico abaixo mostra a diferença entre os valores de tensão teóricos e reais para diversos tipos de baterias. 


\section{Theoretical and Actual Cell Voltages of a Variety of Cell Sytems}

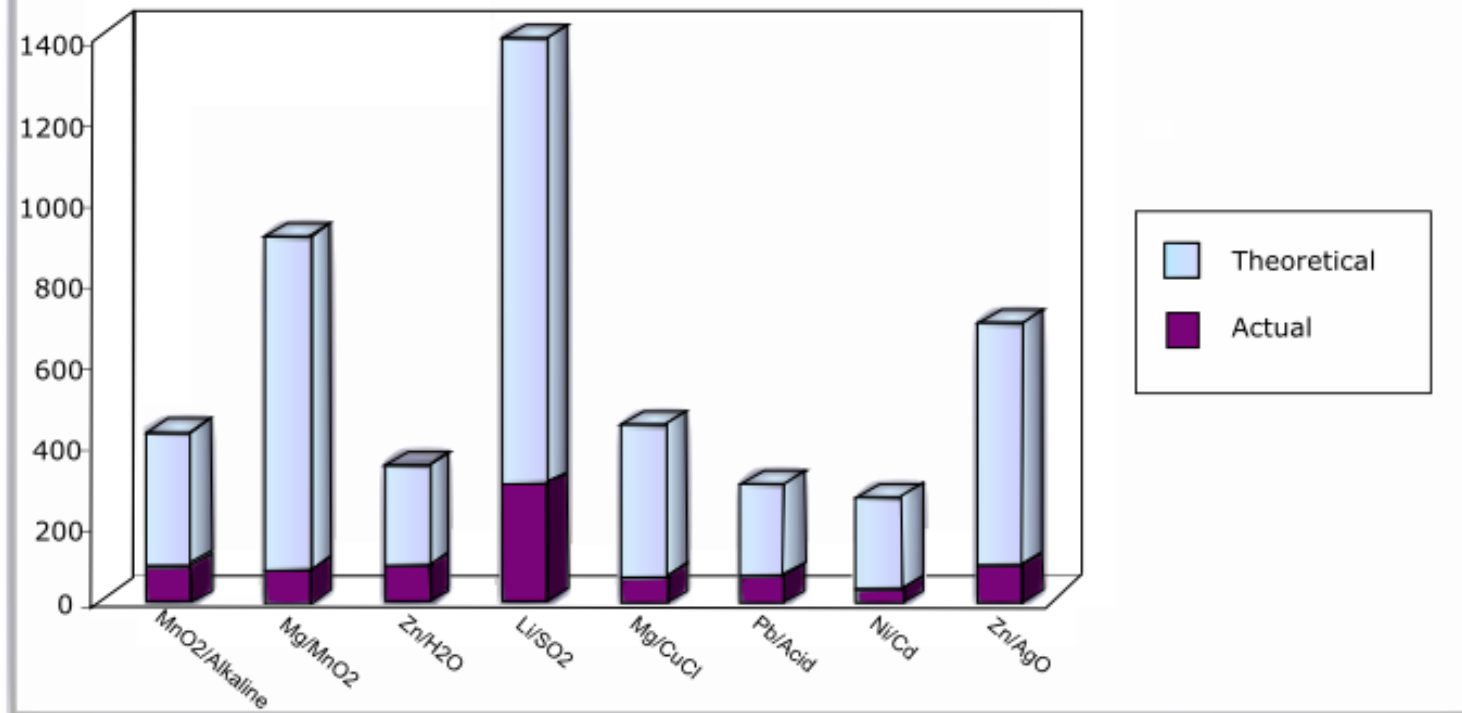

Gráfico 2.1.5 - Valores de tensão teóricos e reais para diversos tipos de baterias Fonte: DoITPoMS - Universidade de Cambridge - UK

\section{Curva de Descarga}

A curva de descarga é um gráfico de tensão por porcentagem de capacidade descarregada. Uma descarga constante é desejável, o que significa que a tensão permanece constante à medida que a bateria vai sendo usada.

\section{Capacidade}

A capacidade teórica de uma bateria é a quantidade de eletricidade envolvida em uma reação química. É representado pela letra Q e é calculado por:

$$
Q=x n F
$$

Onde $\mathrm{x}=$ número de mols de reação; $\mathrm{n}$ - número de elétrons transferidos por mol de reação e $\mathrm{F}=$ constante de Faraday. 
Normalmente a capacidade é fornecida em termos de Massa, não em número de mols.

$$
Q=\frac{n F}{M_{\gamma}}
$$

Onde $\mathrm{M}_{\mathrm{r}}=$ Massa molecular. Assim se obtém a capacidade em Ampere-hora por grama $(\mathrm{Ah} / \mathrm{g})$.

Em prática $100 \%$ da capacidade da bateria nunca será alcançada, por conta de haver uma significante contribuição de componentes não-reagentes como sujeiras, separadores, conectores, encapsulamento etc. OS valores variam entre 0,26AH/g para o Chumbo até 26,59AH/g para Hidrogênio.

\section{Densidade Energética}

A densidade energética é a energia que pode ser extraída por unidade de volume do peso da célula.

\section{Densidade Energética Específica}

A densidade energética específica é a energia que pode ser extraída por unidade de peso da célula (ou ainda por unidade de peso do material do eletrodo). É o produto de uma capacidade específica e a tensão de operação em um ciclo de descarga completo. Tanto a corrente quanto a tensão podem variar durante o ciclo de descarga e então a energia específica obtida é calculada integrando o produto da corrente e tensão em função do tempo. O tempo de descarga está relacionado com o limiar de tensão máxima e mínima e é dependente da disponibilidade de material ativo e/ou em evitar um estado irreversível de recarga da bateria. 


\section{Densidade de Potência}

A densidade de potência é a potência extraída por unidade de peso da célula $(\mathrm{W} / \mathrm{kg})$.

\section{Dependência de Temperatura}

A taxa de reação na célula será dependente da temperatura de acordo com a teoria cinética. A resistência interna também varia em função da temperatura. Baixas temperaturas ocasionam em altas resistências internas. Em temperaturas muito baixas o eletrólito pode congelar resultando assim em baixa tensão por conta de reduzir a movimentação iônica. Em temperaturas muito altas os componentes químicos podem se decompor, ou ainda pode haver energia suficiente para desencadear reações irreversíveis indesejadas, reduzindo a capacidade.

A taxa de queda de tensão com o aumento da descarga será também alta quando em baixas temperaturas, assim como a capacidade. 


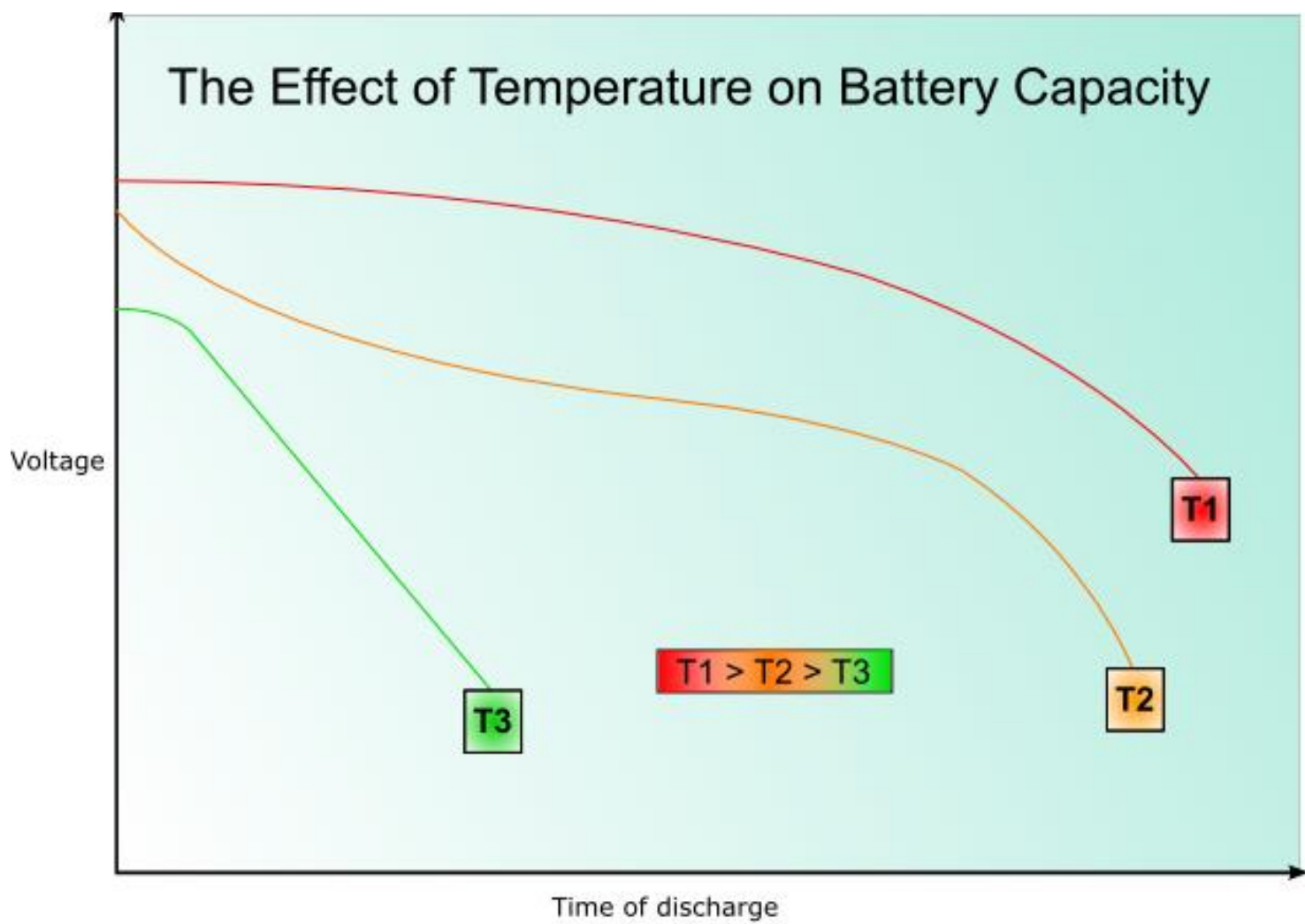

Gráfico 2.1.6 - O Efeito da Temperatura na Descarga da Bateria Fonte: DoITPoMS - Universidade de Cambridge - UK

\section{Tempo de Operação}

O ciclo de vida de uma bateria recarregável é definido pela quantidade de ciclos de carga/descarga que uma bateria secundária pode suportar antes de sua capacidade cair para $80 \%$ do que originalmente tinha. Esse valor gira em torno entre 500 e 1200 ciclos.

O tempo de vida da bateria na prateleira é o tempo em que a bateria pode ficar estocada inativamente antes de sua capacidade cair para $80 \%$. A redução em capacidade com o tempo é causado pela depleção dos materiais ativos por reações indesejadas dentro das células.

Baterias podem ainda ser alvo de "morte prematura" por: 
- Sobrecarga;

- Sobre-descarga;

- Curto circuito;

- Nível de corrente de trabalho maior que o projetado;

- Estar sujeita a temperaturas extremas;

- Estar sujeita a choques físicos ou vibrações.

\section{Aspectos físico-construtivos}

A geometria da célula, o tamanho, peso, formato e posição dos terminais.

\section{Ciclo de Carga/Descarga}

Existem diversos aspectos dos ciclos que necessitam serem levados em conta.

- Tensão necessária para carregar;

- Tempo necessário para carregar;

- Disponibilidade da fonte de energia;

- Segurança quanto aos perigos durante carga/descarga.

\section{Ciclo de Vida}

O ciclo de vida de uma bateria recarregável está relacionado com a quantidade de ciclos de carga/descarga podem ocorrer até que a capacidade seja reduzida para $80 \%$.

\section{Custo}

Deve ser considerado o custo inicial da bateria e também o custo de carga e manutenção da bateria. 


\section{Profundidade de Descarga}

Existe uma relação logarítmica entre a descarga súbita e a vida da bateria. A vida útil da bateria pode ser aumentada significantemente se esta não for completamente descarregada. A vida útil de uma bateria de um telefone celular durará de 5 a 6 vezes mais se reconectar o carregador antes que alcance $80 \%$ de carga, por exemplo.

Baterias de descarga profunda estão disponíveis para aplicações onde seja necessária essa particularidade.

\section{Particularidades de Aplicação}

A bateria deve ser suficiente para o sistema a qual foi projetada. Isto significa que ela deverá fornecer os corretos valores de corrente e tensão, deverá ter capacidade e energia suficientes e ainda não deverá exceder muito os valores projetados para o sistema, até mesmo porque resulta em gastos desnecessários.

Em resumo, a bateria deverá suprir a demanda necessária do sistema com o menor custo possível.

\section{Riscos Associados às Baterias}

\section{Explosão}

A explosão de uma bateria pode ser causada por mal-uso ou mesmo defeito de fabricação, como em tentar carregar uma pilha primária, ou ainda fechar um curtocircuito. As baterias automotivas estão mais sujeitas à explosão quando ocorre um curto- circuito gera altos níveis de corrente. Esse tipo de bateria em específico produz hidrogênio, o qual é altamente explosivo, quando se está em sobrecarga (por conta da 
eletrólise da água com o eletrólito). A sobrecarga aplicada nesse tipo de bateria em específico é normalmente baixa, a fim de gerar baixas quantidades de hidrogênio o qual se dissipa rapidamente. No entanto se ocorrer um curto-circuito, um elevado nível de corrente pode causar uma rápida liberação de grandes volumes de hidrogênio, podendo ser explodido por uma fonte de ignição por perto, por exemplo, desconectando um cabo de vela do distribuidor.

Quando a bateria é recarregada a um nível demasiado, uma mistura explosiva de gás hidrogênio e oxigênio pode ser produzida em uma quantidade maior que a vazão das válvulas de segurança estão projetadas para suportar, aumentando assim a pressão interna e uma eventual quebra do invólucro da bateria (LINDEN; REDDY, 2011, cap. 16). Em casos extremos, o ácido da bateria pode espirrar e causar ferimentos. Sobrecarga, que nada mais é que aplicar uma carga acima do limite recomendado, pode também resultar em explosão da bateria, também resultando em vazamento de ácido e danos irreversíveis. Pode ainda causar danos ao carregador ou dispositivo em que essa bateria sobrecarregada seria posteriormente utilizada. Se a bateria for exposta ao fogo também pode causar sua explosão, por conta da fumaça gerada internamente e impossibilidade de se remover essa fumaça. 


\section{Vazamento}

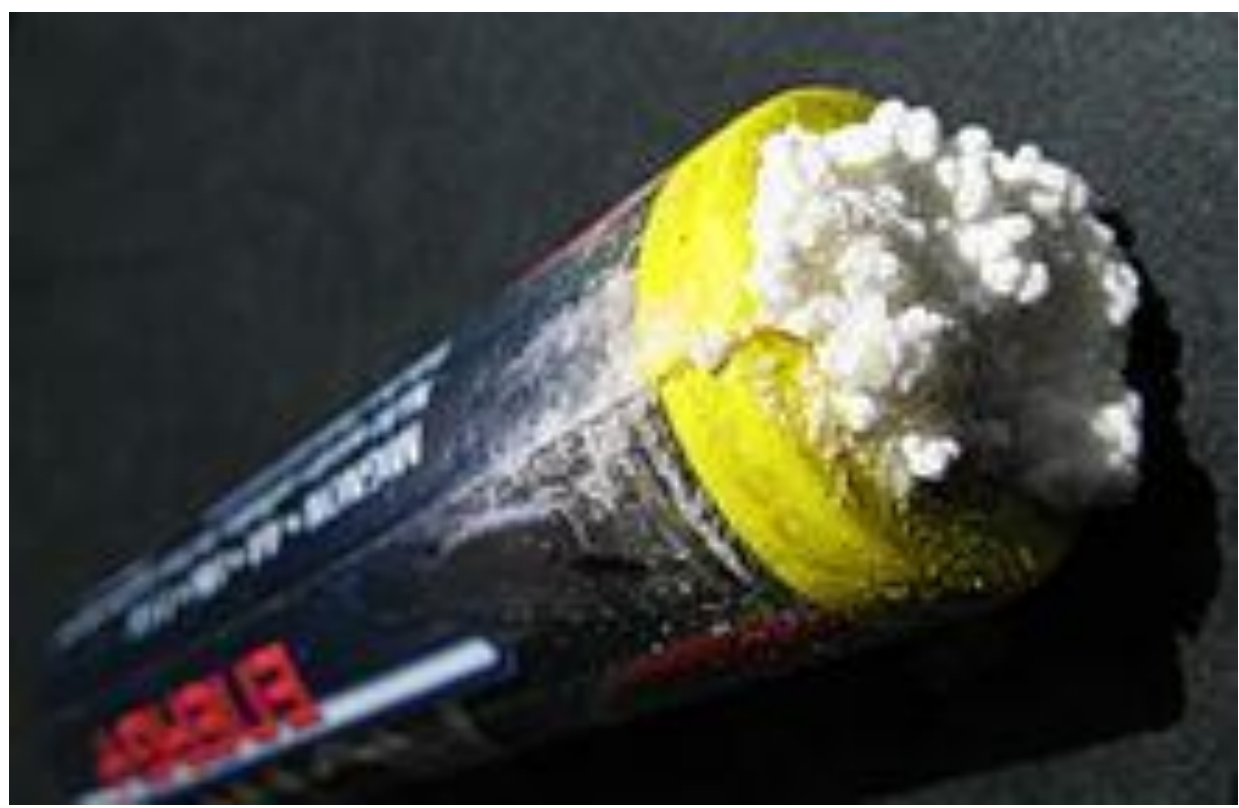

Figura 2.1.7 - Pilha Alcalina com Vazamento Fonte: Túrelio - Wikimedia Commons

A maior parte dos componentes químicos das baterias são corrosivos, venenosos ou as duas coisas. Se um vazamento ocorrer, espontaneamente ou por acidente, o componente químico desprendido pode ser perigoso.

Por exemplo, o Zinco presente em algumas baterias pode ser o material reagente ou ainda entrar em contato com outros reagentes. Se este tipo de bateria está sobre descarregada, os reagentes podem emergir através do papel-cartão e do plástico que formam o invólucro. O vazamento desse líquido pode ainda causar danos ao circuito do equipamento. Por essa razão que diversos fabricantes de componentes eletrônicos recomendam a remoção das baterias dos dispositivos que não serão usados por um longo período (LINDEN; REDDY, 2011, cap. 8). 


\section{Materiais Tóxicos}

Na construção de diversos tipos de baterias são empregados materiais tóxicos como: chumbo, mercúrio e cádmio como eletrodo ou eletrólito. Quando uma bateria alcança o fim de sua vida útil deverá ser disposta em locais específicos e destinados a essa finalidade, para que se evite danos ao meio ambiente. As baterias deverão ser recicladas e, com o material tóxico recuperado e separado, pode até mesmo ser usado em novas baterias.

Nos Estados Unidos, o Mercury-Containing and Rechargeable Battery Management Act de 1996 baniu a venda de baterias contendo mercúrio, padronizou identificações para baterias recarregáveis e obrigou que as baterias recarregáveis fossem facilmente removidas. Na Califórnia e em Nova Iorque é proibida a disposição de baterias recarregáveis em lixo comum. As indústrias de baterias recarregáveis têm programas de reciclagem em todo o país, com fornecimento de "pontos de recolhimento de baterias usadas" nas lojas e supermercados. Ações semelhantes são aplicadas nos outros lugares do mundo também.

\section{Ingestão}

As baterias podem ser prejudiciais e ainda fatais se engolidas. Pequenas baterias de íons de lítio podem ser engolidas por crianças pequenas. Enquanto estiver no trato digestivo, pode ocorrer uma descarga elétrica da bateria nos tecidos, podendo causar sérios danos e ainda levar a morte.

A ingestão desse tipo de bateria não costuma ser um problema, a não ser que ela fique encarcerada no trato gastrointestinal. O local mais comum para essas baterias 
ficarem alocadas no corpo humano é no esôfago, causando seqüelas (ENERGIZER, 2015).

\section{2 - Bateria Automotiva}

Em um veículo automóvel - utilizada principalmente no ciclo de partida do motor à combustão - a bateria é responsável por fornecer uma grande quantidade de energia para um motor elétrico (conhecido como motor de arranque) acoplado ao motor à combustão, permitindo dessa forma que quando a bateria abastece o alternador, se inicie o ciclo Otto.

Porém o fato desse ciclo de partida demandar uma grande quantidade de corrente elétrica em um curto espaço de tempo, bem como a constante variação da temperatura ambiente em que se encontra instalada a bateria, a vida útil da bateria acaba sendo reduzida e, sem outra aplicação, a bateria acaba sendo destinada para centros de reciclagem. Atualmente uma bateria automotiva tem a vida útil média de 2 a 3 anos.

A bateria chumbo-ácida desenvolvida para uso automotivo utiliza um grande número de placas com espessura pequena, com o intuito de maximizar a área útil da placa e assim obter uma elevada taxa de corrente para a carga. No entanto se a bateria for submetida a sucessivos ciclos de descarga longos, acabará resultando em perda de capacidade e falhas, por conta da degradação física dos eletrodos sofrida durante esses ciclos. Essa degradação nada mais é que a perda de chumbo, o qual vai decantando no fundo da célula da bateria, até o momento em que acaba colocando a célula em curtocircuito, inutilizando-a. Outra falha comum de acontecer é manter essa bateria sob constante carregamento, o que acaba originando corrosão dos eletrodos. 
Por último, se a bateria é mantida desconectada por um longo período, ou se o carregamento é insuficiente durante sua operação normal, ocorre a cristalização do sulfato de chumbo. Dessa forma o sulfato de chumbo cristalizado é uma estrutura quimicamente estável, perdendo a propriedade de se transformar novamente em chumbo, óxido de chumbo e ácido sulfúrico. Sendo assim, o chumbo não retorna mais para as placas, consequentemente a quantidade de material útil necessário não é suficiente resultando assim incapacidade de geração/armazenamento com o passar do tempo.

Esse ambiente em que não se tem a temperatura controlada acaba contribuindo para o desgaste precoce da bateria, fazendo com que a mesma demande uma quantidade adicional de corrente - chamado de perda térmica - para manter a tensão de flutuação.

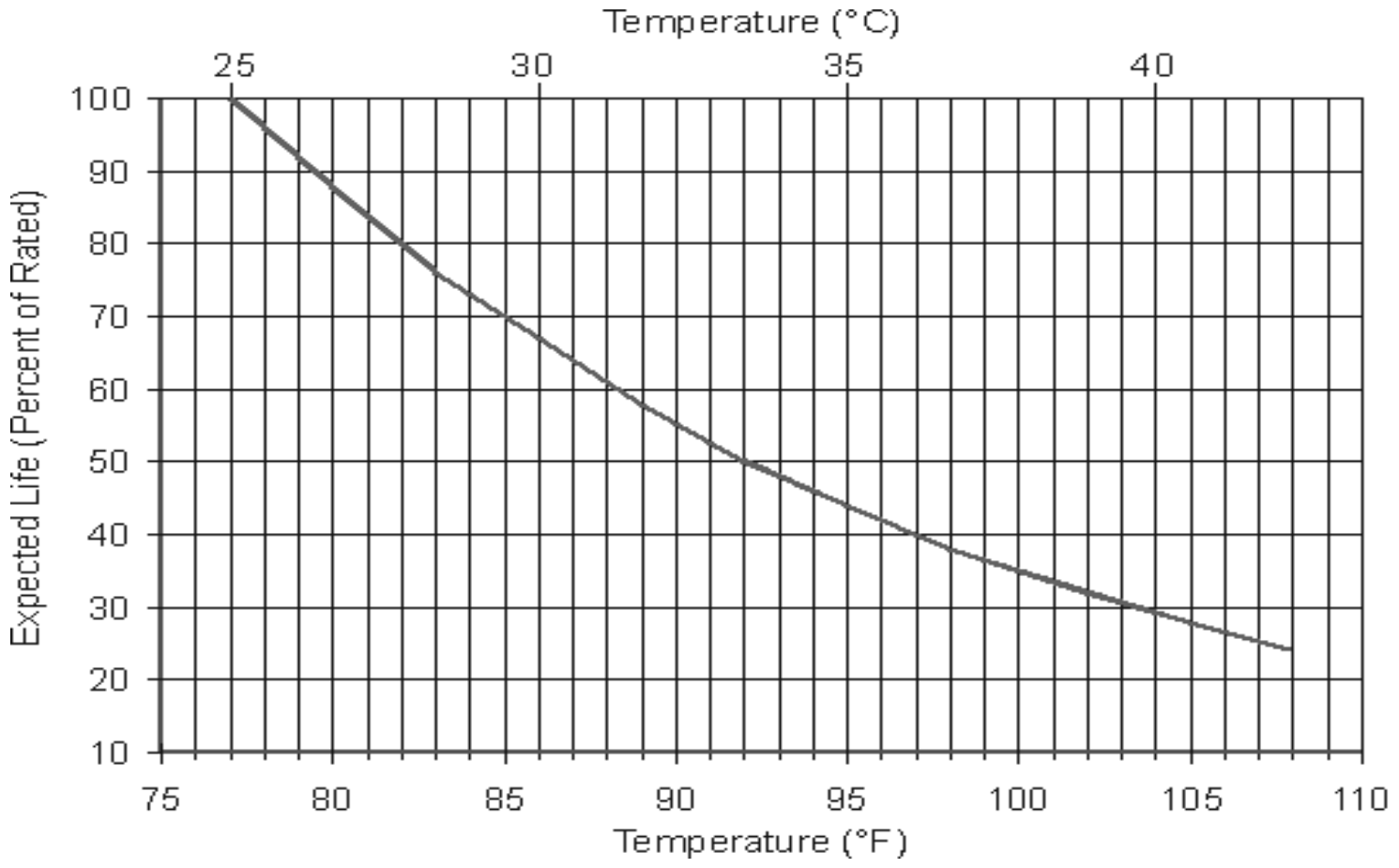

Gráfico 2.2.1 - Vida útil estimada da bateria, em função da temperatura Fonte: Linden's Handbook of Batteries 
A faixa de temperatura recomendada durante a operação da bateria Chumboácida está entre $20^{\circ} \mathrm{C}$ e $25^{\circ} \mathrm{C}$ (LINDEN; REDDY, 2011, cap. 16). Baterias usadas em regime estacionário tendem a ter uma vida longa, comparada com as automotivas.

Quando a bateria está em regime de operação desbalanceada ou de sobrecarga, em um modo de recombinação constante, toda a energia gasta nessa sobrecarga resulta em geração de calor. Se a reação de recombinação acaba gerando um calor maior que o da dissipação, a temperatura da bateria se eleva e uma maior corrente se faz necessária para manter a tensão de carregamento. Esse adicional de corrente resulta em mais recombinação e geração de calor, o que eleva a temperatura na bateria. O resultado final dessa reação desencadeia na evaporação do eletrólito, diminuindo assim a vida útil da bateria. Esse efeito poderia ser minimizado se houvesse um sistema de ventilação para a bateria, ou ainda um sistema de carregamento que variasse em função da temperatura do ambiente.

Algumas condições que podem contribuir na perda térmica:

- Alta temperatura ambiente;

- Tensão de carregamento mal ajustada, ou falha no regulador de tensão gerando uma alta tensão, ou uma alta tensão de ripple;

- Falha de uma ou mais células da bateria (defeito de placas coladas);

- Ventilação e controle de temperatura deficientes.

Falhas resultadas pelo efeito de perda térmica:

- Alta corrente de carregamento e recombinações insuficientes resultam em geração de elevadas taxas de Hidrogênio $\left(\mathrm{H}_{2}\right)$ e Oxigênio $\left(\mathrm{O}_{2}\right)$;

- Eventual secagem da bateria;

- Dependendo do caso pode resultar em uma combustão e explosão. 
Conforme mencionado anteriormente, a forma de carregamento da bateria chumbo-ácida, bem como a não observância de alguns fatores durante o processo de carregamento acarretam na diminuição da vida útil da bateria. A forma correta de recarga é importante para se obter uma melhor vida útil em qualquer condição de uso. Abaixo estão listadas algumas regras para a forma correta de se carregar a bateria, e se aplica para todos os tipos de baterias chumbo-ácidas.

$\checkmark$ A corrente aplicada na bateria no início do carregamento não deverá produzir tensão superior a $2,4 \mathrm{~V}$ por célula, a fim de se evitar perda por evaporação;

A corrente deverá ser controlada a fim de manter o nível de tensão abaixo do limiar de produção gasosa durante todo o processo de recarga e até que a bateria esteja completamente carregada;

$\checkmark$ Quando a bateria estiver próximo de atingir o nível de 100\% carregada, o nível de corrente vai caindo aos poucos. Para finalizar a recarga deverá ser mantida uma corrente constante, normalmente em torno de 5A para cada 100Ah de capacidade.

Diversos métodos de recarga foram desenvolvidos a fim de se atenda essas recomendações acima descritas, dependendo da capacidade. O método que mais se aproxima ao apresentado neste trabalho é o carregamento por tensão constante.

\section{- Carregamento por Tensão Constante: Essa forma de carregamento é} comumente usada em indústrias, veículos automotores, sistemas de abastecimento de energia, telefonia e sistemas ininterruptos de fornecimento de energia, onde o 
carregador está vinculado ao banco de baterias. Neste caso existe uma limitação para a corrente de carregamento, e essa corrente é mantida no limite até que um valor de tensão pré-determinado é alcançado. Então a tensão é mantida constante até o momento em que a bateria é usada para suprir a energia.

Os cálculos de limites de corrente e tensão deverão ser feitos levando-se em conta o ambiente em que se encontram as baterias, a forma como estão ligadas (em série ou em paralelo), quantas baterias estão em um mesmo banco e também o tempo de descarga/recarga. Para esse tipo de operação em que a bateria permanece constantemente sendo carregada, uma baixa corrente deverá ser considerada, a fim de se evitar sobrecarga, corrosão das placas por conta da sobrecarga, perda de água por eletrólise e ainda manutenção do nível de água.
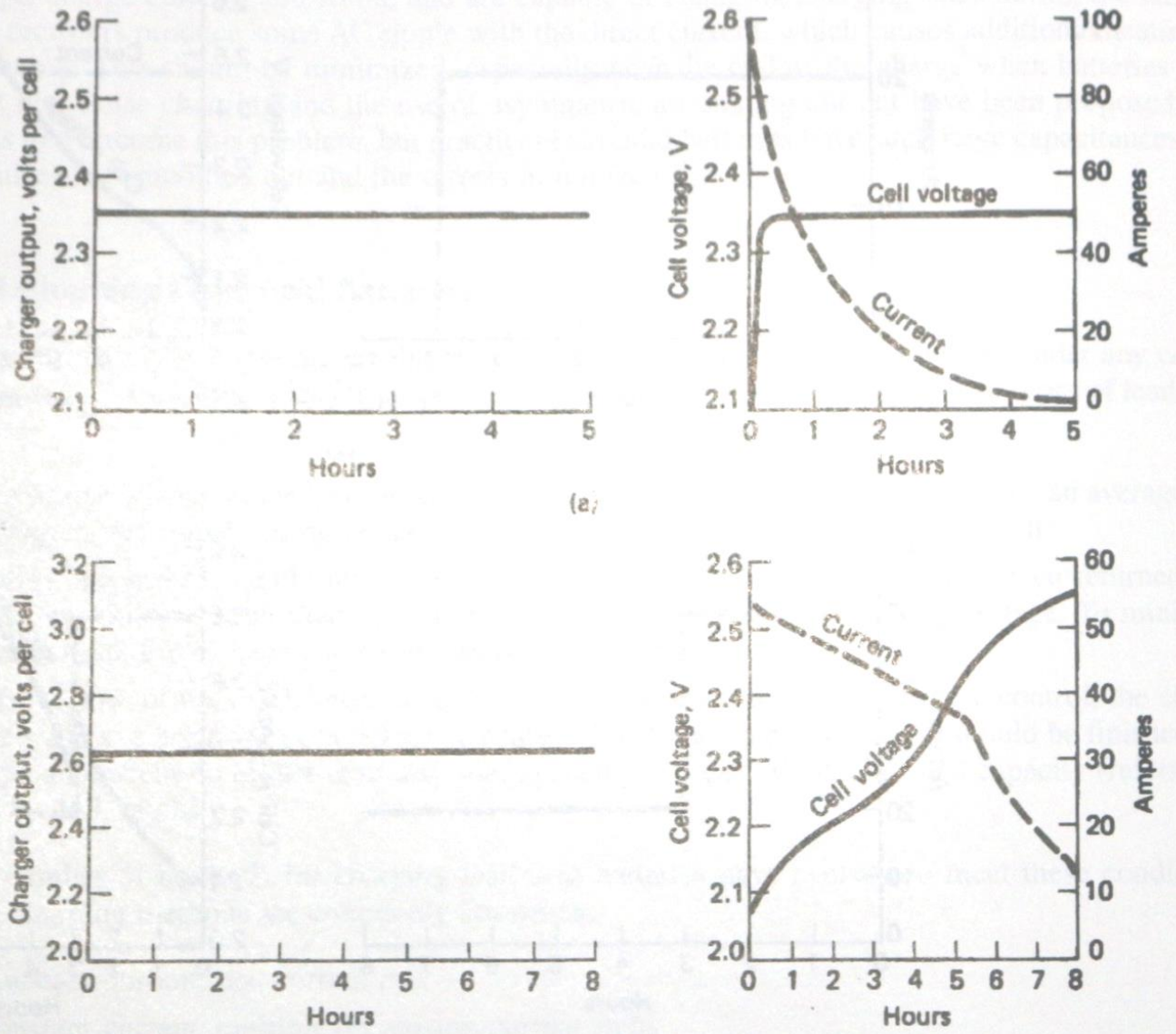

Gráfico 2.2.2 - Curvas características do Carregamento por Tensão Constante Fonte: Linden's Handbook of Batteries 
Uma forma modificada de carregamento por tensão constante, com valores iniciais e finais constantes, é comum para baterias que são usadas em longos ciclos de descarga, que normalmente chegam a $80 \%$ de descarga em um ciclo de 6 h de uso. Em contrapartida essa bateria normalmente é carregada em um período de 8 horas. O carregador é ajustado para a tensão de $2,39 \mathrm{~V}$ por célula (valor bem próximo ao limiar), e a corrente inicial é limitada entre 16A e 20A para cada 100Ah. Essa corrente inicial é mantida constante até que a tensão média por célula atinge $2.39 \mathrm{~V}$. A corrente então é diminuída para em torno de 5,0A para cada 100Ah, mantendo-se assim a tensão constante até que as baterias estejam 100\% carregadas. O tempo total de carregamento pode ser controlado por um relé de tempo, a fim de evitar uma sobrecarga. Esse tempo de 8 horas também pode ser reduzido aumentando a corrente inicial de recarga (LINDEN; REDDY, 2011, cap. 17).

Uma variação também desse método de carregamento é utilizado para manter as baterias sempre $100 \%$ carregadas, aplicando-se uma baixa tensão nas baterias. Esse método é chamado de Carregamento Flutuante, e é usado principalmente para baterias estacionárias que podem ser carregadas por um barramento CC. A tensão de flutuação para um banco de baterias contendo uma gravidade específica do eletrólito de 1,210 e a tensão de circuito aberto de $2,059 \mathrm{~V}$ por célula é de $2,17 \mathrm{~V}$ a 2,25V por célula.

No entanto, essa bateria usada pode não servir para uma aplicação de alta corrente demandada, porém pode ser usada em outras aplicações que não necessitam desse alto nível corrente. Dessa forma algo que iria para o "lixo", pode servir para abastecer algum equipamento elétrico/eletrônico em alguma região carente dessa energia, seja por condições sócio-econômicas (vilarejos, aldeias), seja por condições geográficas (ilhas, embarcações). 


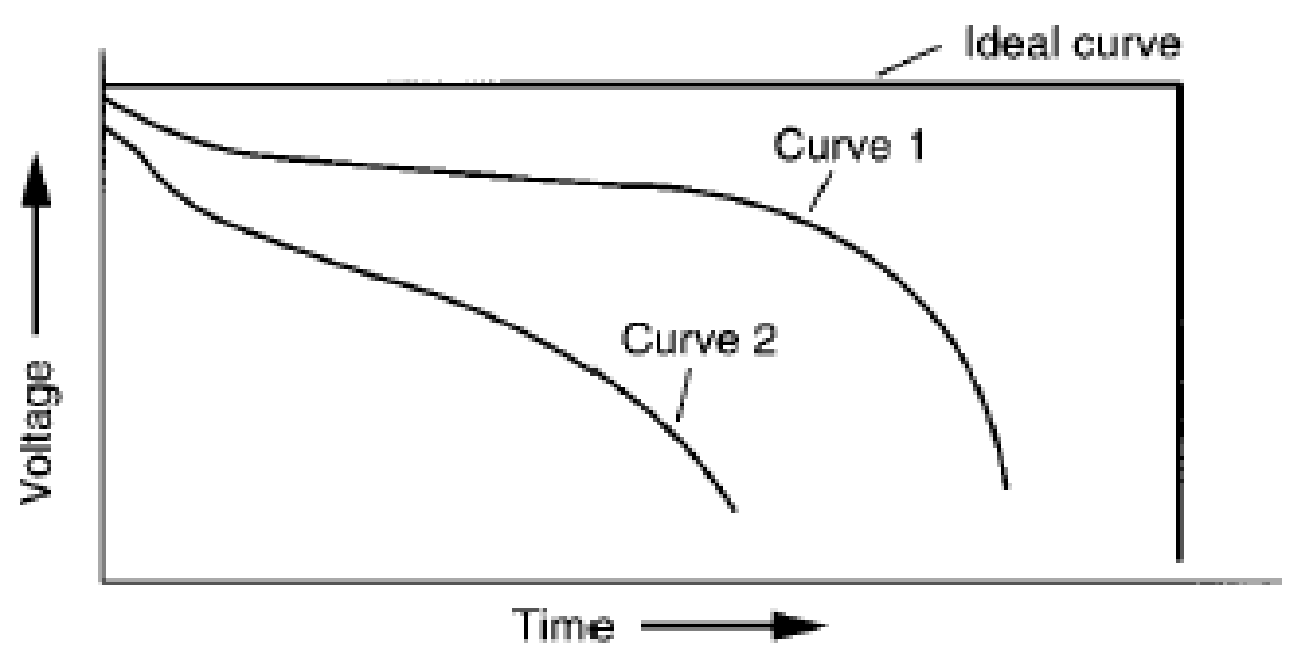

Gráfico 2.2.3 - Curva VxT para descarga da Bateria

Fonte: Prof. Dr. Mário Kawano

O fato de a bateria carregar e descarregar constantemente durante os inúmeros processos de partida de um veículo faz com que a quantidade de tensão fornecida durante um intervalo de tempo diminua a vida útil da bateria. Isso se deve ao fato da reação química que acontece no interior da bateria ficar limitada, por conta de oxidação das placas e, consequentemente, diminuição do fluxo de corrente elétrica por elas.

Para esse trabalho foi escolhida a bateria Chumbo-Ácida reciclada, que é a bateria usada nos automóveis. Apesar de já ser considerada uma unidade de baixo custo, ainda assim pode ser considerada custosa para sociedades de baixa renda, dependendo da aplicação final. No entanto as baterias recicladas estão mais sujeitas a falhas como curto-circuitação de células, vazamento de ácido etc., podendo prejudicar o sistema como um todo por conta de estarem ligadas em paralelo no banco de baterias. Dessa forma a unidade seria considerada como carga, e não como fonte. 


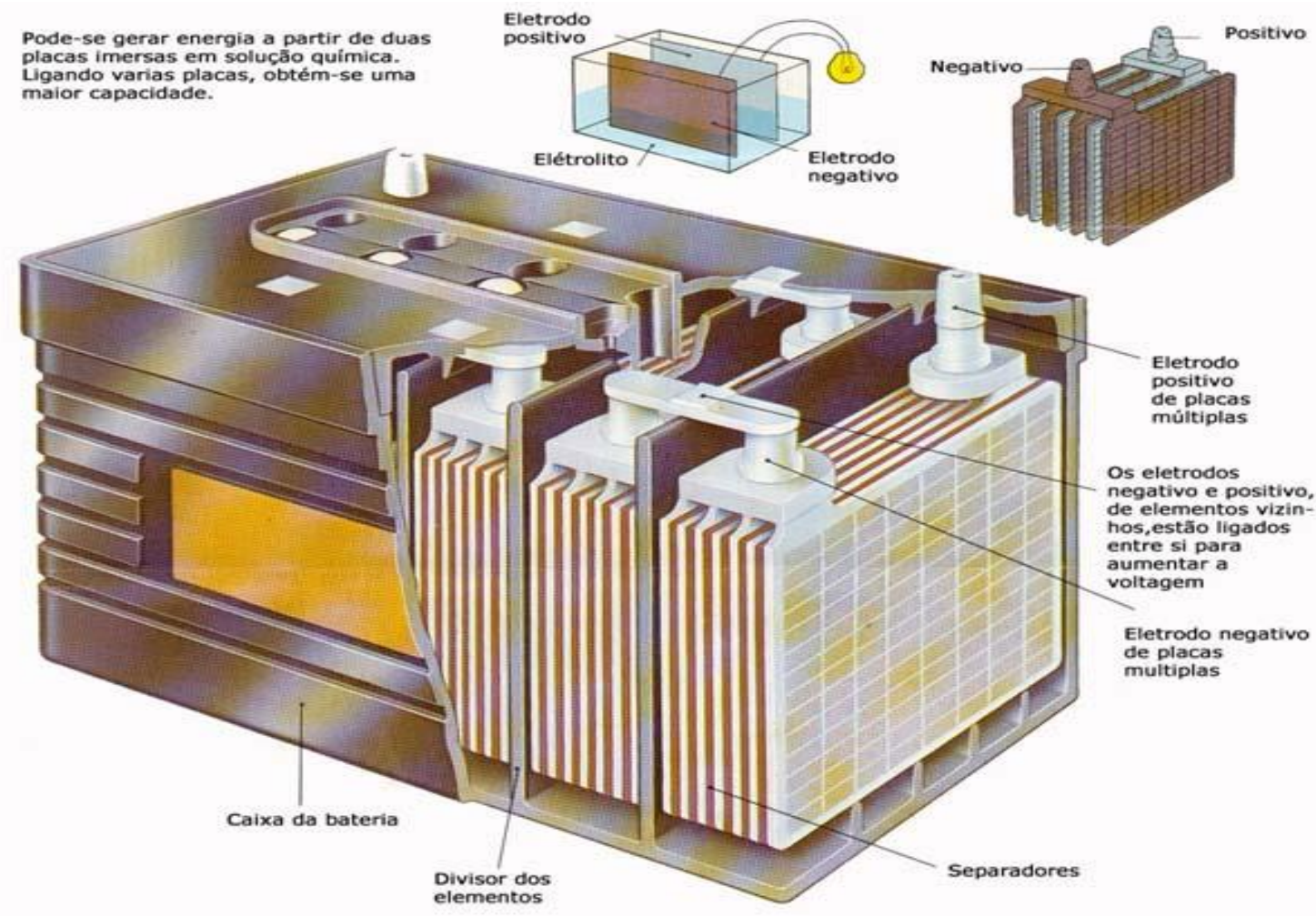

Figura 2.2.4 - Visão em corte de uma bateria Chumbo-Ácida

Fonte: Núcleo de Pesquisa de Ciências

A fim de se evitar esse problema, um monitoramento constante da corrente fornecida pela bateria e tensão em circuito aberto já ajudam a identificar a unidade defeituosa. Se não existe corrente durante o processo de fornecimento de energia, ou ainda se o nível de tensão em circuito aberto for menor que o valor nominal, esses já são fatores que determinam se uma bateria está boa ou não.

Tendo um monitoramento completo do banco de baterias possibilita o uso de baterias novas em conjunto com baterias recicladas. As baterias novas nesse caso ajudariam a manter o "sistema vivo" em caso de precisar isolar mais baterias por conta de falhas. Neste caso uma seletividade para as cargas instaladas pode ser necessário, a fim de manter energizado somente o que é essencial nesse caso.

Outro fator que comprometeria a vida útil do sistema seria uma fuga de corrente dentro da própria bateria, por formação de condensado no interior por conta de 
uma sobrecarga e, como consequência, diminuir a capacidade de fornecimento. A fuga de corrente pode ainda prejudicar o sistema durante o carregamento, por conta de demandar um alto nível de corrente e podendo chegar ao limite da geração. Sendo assim, toda a potência gerada pelas células solares acaba sendo destinada exclusivamente para essa bateria em falha. No entanto é fato que alguns equipamentos ligados como carga também podem gerar fugas de corrente, por falha na isolação de um condutor, por curto-circuito em uma placa de circuito impresso causado por algum inseto, dentre outros.

\section{3 - Sensor de corrente}

O Módulo Sensor de Corrente é um componente eletrônico desenvolvido para aplicação em diversos circuitos elétricos. Por meio do Arduino, AVR, PIC, Raspberry PI, ou outras plataformas de prototipagem é possível, aplicando o módulo sensor de corrente, medir o consumo de motores, por exemplo. Mas, por que medir o consumo de um componente elétrico?

A medição desta corrente é necessária para calcular o consumo de determinado eletrônico e consequentemente calcular o tempo de duração da carga de uma bateria, por exemplo, ou para ao final do mês calcular o consumo de um eletrodoméstico. É uma informação importante que pode servir para diagnosticar se determinado circuito anda consumindo mais energia do que deveria, entre outros fins.

O Módulo Sensor de Corrente é um simples componente, extremamente útil, que oferece informações importantes aos microcontroladores, deixando o operador ciente da corrente consumida pelo componente elétrico ligado ao sensor. Uma característica a ser destacada do Módulo Sensor de Corrente é sua capacidade de medir 
correntes AC (alternadas) e correntes DC (contínuas) variando desde baixos níveis de corrente em torno de $5 \mathrm{~A}$ até altos valores de até $1000 \mathrm{~A}$, diferindo apenas seu encapsulamento. Existem vários benefícios que o Módulo Sensor de Corrente pode oferecer ao seu projeto, dando informações precisas sobre o que acontece com seus componentes elétricos.

\section{PRINCIPAIS CARACTERÍSTICAS:}

- Medidor de corrente AC / DC;

- Mede o consumo de componentes elétricos;

- Compatível com Arduino, Raspberry PI, PIC, AMR, etc.;

- Excelente relação custo x benefício;

- Compacto.

\section{ESPECIFICAÇÕES:}

- Tensão de alimentação: 5V;

- Corrente máxima: 5A;

- Tempo de resposta: 5uS;

- Largura de banda: 80Khz;

- Margem de erro: $1.5 \%$ a $25^{\circ} \mathrm{C}$;

- Resistência interna: 0.0012 ohm (1.2m ohm);

- Tensão de isolação: 2.1KVRMS;

- Razão de saída: 185mV por Ampere;

- Dimensões (CxLxA): 31x13x12mm;

- Peso com embalagem: 4g. 


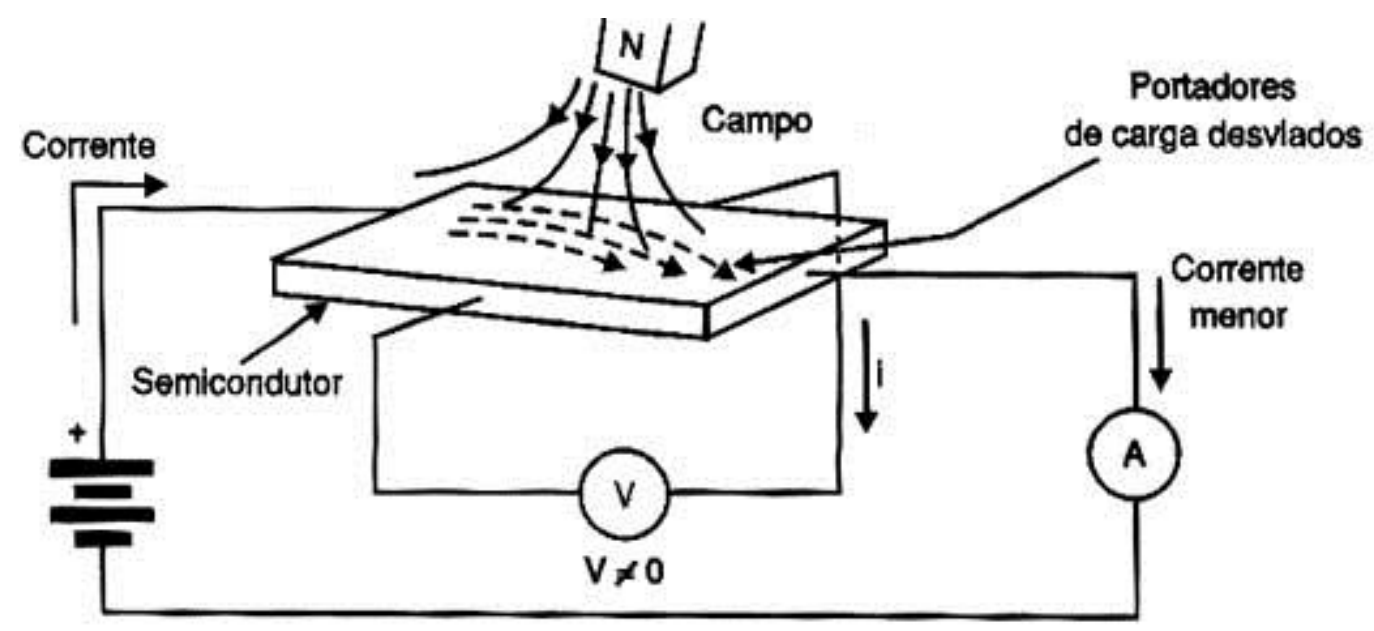

Figura 2.3.1 - Princípio de Funcionamento do Sensor de Efeito Hall

Fonte: Instituto Newton C. Braga

\section{Princípio de Funcionamento}

Um semicondutor sob a aplicação de um campo magnético, demonstrando o Efeito Hall. Se uma diferença de potencial é aplicada a um material semicondutor de modo que flua uma corrente, e ao mesmo tempo o este material é submetido a um campo magnético, no deslocamento através deles as cargas tendem a se desviar de sua trajetória normal, acumulando-se numa das faces laterais, e com isso uma tensão será detectada.

Os sensores de campos magnéticos são dispositivos muito utilizados e presentes em nosso dia-a-dia e que possuem diversas aplicações, desde aparelhos de consumo até máquinas industriais. Uma das maneiras mais elementares de se fazer o sensoriamento de campo magnético e por meio de uma bobina. Existem, contudo, dispositivos semicondutores próprios para a detecção de campos magnéticos, como é o caso do Sensor Hall. 
O Sensor Hall tem seu princípio de funcionamento baseado no Efeito Hall, descoberto em 1889, por Edwin Hall (RAMSDEN, 2006). O efeito Hall é uma propriedade que se manifesta em um condutor quando um campo magnético perpendicular ao fluxo de corrente é aplicado sobre ele. Quando isso ocorre, uma diferença de potencial no condutor é gerada, chamada de Tensão de Hall. Esta tensão possuí direção perpendicular ao campo magnético e à corrente, e é proporcional à densidade de fluxo magnético e à corrente. O campo magnético aplicado provoca um gradiente de concentração de portadores em todo o condutor. Quando o número de portadores de um lado do condutor for maior do que do outro, então surgirá esta diferença de potencial. A amplitude da tensão de Hall varia com a corrente e o campo magnético.

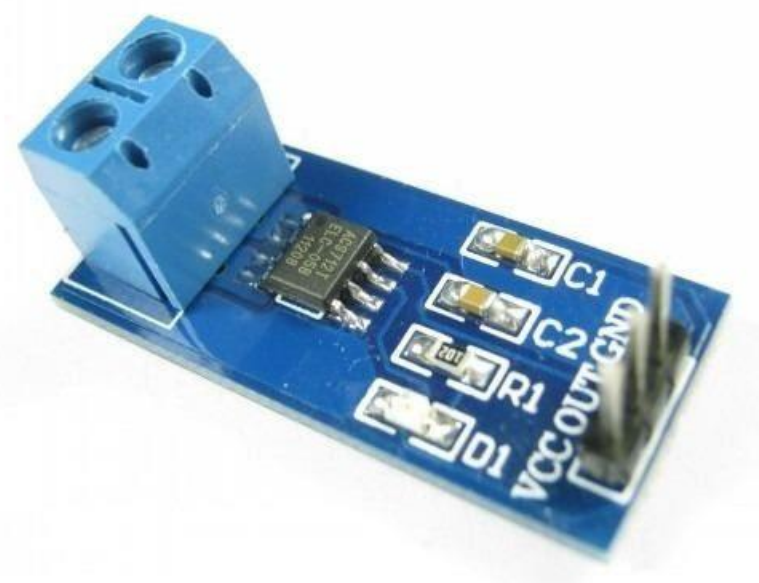

Figura 2.3.2 - Sensor de Efeito Hall para interface com periféricos Fonte: Prof. Dr. Roberto K. Onmori

Em resumo, o Efeito Hall é o que ocorre quando uma corrente num condutor tem sua trajetória desviada pela ação de um campo magnético. Com um formato 
apropriado, este desvio faz com que a Tensão de Hall seja gerada, e esta pode ser aproveitada por um circuito externo, e é o que sensores Hall fazem. A tensão de Hall pode ser medida por um circuito externo ou ainda ser utilizada para efeitos de sensoriamento, pois ela é proporcional à intensidade do campo que cria.

O Efeito Hall é um efeito observado em todos os materiais. Contudo, sua aplicação é eficaz somente em materiais onde a mobilidade eletrônica seja relativamente alta. Desse modo, as aplicações práticas do Efeito Hall só se tornam possíveis com o desenvolvimento de tecnologias em materiais semicondutores.

\section{Dispositivo Semicondutor}

Sensores que utilizam Efeito Hall são tipicamente construídos de materiais semicondutores, permitindo que a eletrônica seja desenvolvida no mesmo material. Para tal podem ser utilizados materiais semicondutores tipo $\mathrm{p}$ ou tipo n. Quando o sistema possuí uma alta mobilidade de carga, a Constante Hall terá um valor relativamente grande, permitindo que se obtenha melhores valores de saída. Para que se tenha uma razão sinal/ruído (SNR) alta, é necessária que a resistividade do material seja baixa, limitando, assim, a diferença de potencial gerada por ruído térmico. Estas condições são otimizadas ao se utilizar um semicondutor tipo $\mathrm{N}$.

Podemos encontrar comercialmente sensores de Efeito Hall tanto na sua forma simples como em configuração em ponte. Uma das vantagens da utilização da configuração em ponte é que ela permite realizar a detecção de variações do campo em ambos os sentidos, simplificado o projeto de circuitos detectores.

Os sensores de efeito Hall podem ainda ser encontrados com saída Analógico/Linear ou digital. 


\section{O Sensor Analógico/Linear}

O sinal de saída dos sensores analógicos (lineares) é gerado diretamente a partir da saída do amplificador operacional com a tensão de saída sendo diretamente proporcional ao campo magnético que passa pelo sensor Hall.

Os sensores lineares analógicos fornecem uma tensão de saída que aumenta com um campo magnético forte e diminui com um campo magnético fraco. Em sensores de efeito Hall de saída linear, a medida que a força do campo magnético aumenta, o sinal de saída do amplificador também irá aumentar até que ele comece a saturar devido ao limites impostos pela fonte de alimentação. Qualquer aumento adicional no campo magnético não terá qualquer efeito sobre a saída, mas irá dirigi-lo mais rápido para a saturação.

De modo geral, a maioria dos sensores lineares Hall são do tipo "relaciométrico" (ratiometric) ou seja, existe uma tensão de saída quiescente, normalmente metade da tensão de alimentação e esta tensão varia para mais ou menos em relação a este valor, conforme o campo magnético de saída. 


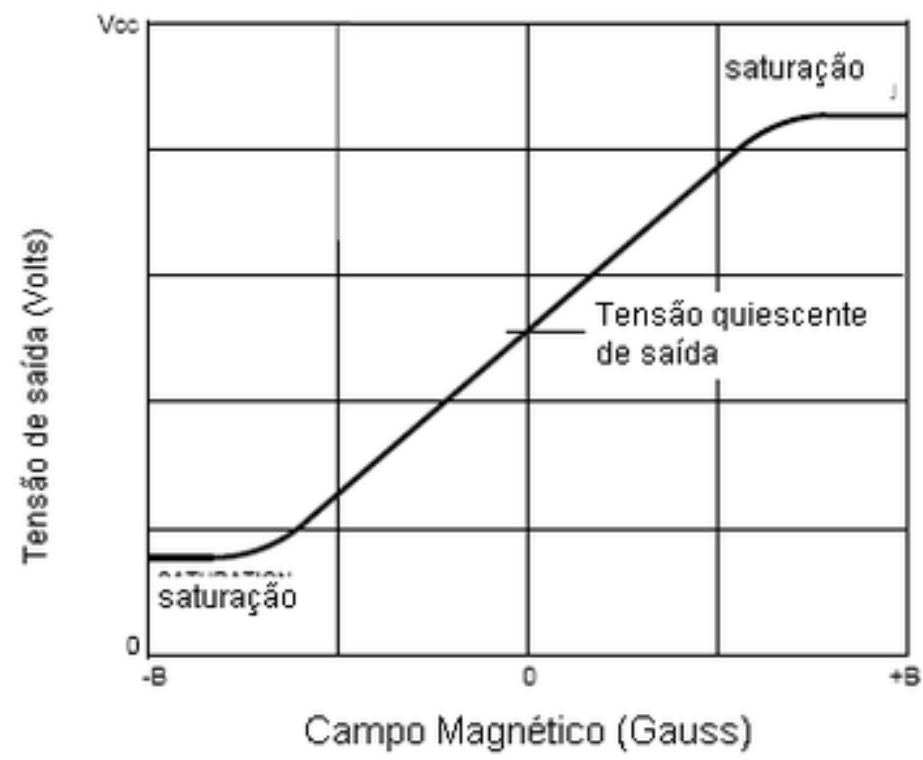

Figura 2.3.3 - Característica de um sensor Hall relaciométrico comum Fonte: Prof. Dr. Roberto K. Onmori

A sensibilidade é dependente da tensão de alimentação, assim, se houver um aumento da tensão de alimentação, muda a tensão quiescente e as variações em torno deste valor passam a ter uma amplitude maior para uma mesma variação da intensidade do campo.

\section{O Sensor Digital}

Sensores de saída digital, por outro lado tem um Disparador Schmitt construído em histerese e ligado ao amplificador operacional. Quando o fluxo magnético que passa através do sensor Hall excede um valor pré-definido, a saída do dispositivo muda rapidamente de sua condição "DESLIGADA" para a uma condição "LIGADA" sem qualquer tipo de rejeição de contato. Esta histerese embutida elimina qualquer oscilação do sinal de saída enquanto o sensor se move para dentro e fora do campo magnético. Assim, os sensores de saída digital tem apenas dois estados, "LIGADO" e "DESLIGADO". 
Existem alguns parâmetros destes sensores que são importantes para a compreensão de seu funcionamento, são eles:

- Bop: Ponto de operação magnético; é o nível de campo magnético a partir do qual um dispositivo Hall liga. O estado resultante do dispositivo depende do design individual do dispositivo eletrônico.

- Brp: Ponto de liberação magnética; é o nível de campo magnético a partir do qual um dispositivo Hall desliga (ou para alguns dispositivos Hall, o nível crescente de campo negativo dado um positivo Bop). O estado resultante da saída do dispositivo depende do design individual do dispositivo eletrônico.

- Bhys: Histerese magnética. A função de transferência de um dispositivo Hall é desenhado com este offset entre os pontos de chaveamento para filtrar pequenas flutuações no campo magnético que poderiam resultar de vibrações mecânicas ou ruído eletromagnético na aplicação. $B H Y S=|B O P-B R P|$.

Podemos encontrar quatro tipos de sensores Hall Digitais, são eles:

\section{Unipolar}

Esse tipo de sensor opera em um campo magnético positivo, ou seja, o sensor só irá conduzir quando o polo positivo de um ímã de aproximar dele. Enquanto o ímã estiver próximo do sensor, ele continuará conduzindo. A condução só é cessada quando o ímã é afastado.

\section{Bipolar}

Este tipo de sensor opera sob qualquer tipo de campo magnético, mantendo sua saída acionada na presença de um pólo sul magnético, sendo desligado apenas na 
presença de um pólo norte magnético. Ele é usado em aplicações onde os pólos sul e norte de ímãs se encontram muito próximos, como em um anel de ímãs em motores.

\section{Omnipolar}

Este tipo de sensor, assim como o Bipolar, é capaz de detectar qualquer tipo de campo magnético, contudo o seu princípio de operação é muito parecido ao Unipolar, desse modo, o sensor Omnipolar só opera sob a presença de um ímã. Esse tipo de sensor simplifica a montagem de um projeto, uma vez que não é necessário conhecer o pólo do ímã que ficará voltado para o sensor.

Chave de efeito Hall omnipolar. O gráfico é parecido com o sensor unipolar, porém agora existe o lado negativo do gráfico. A linha vermelha apresenta um campo magnético crescente, que quando atinge o Brp do pólo magnético norte, desaciona o sensor. Este volta a ser acionado quando o Bop de pólo sul magnético é atingido. O mesmo pode ser obtido em sentido contrário.

\section{Latch de Efeito Hall}

Este sensor tem sua entrada acionada na presença de um ímã e a mantém acionada até que o imã se aproxima novamente do sensor. 


\section{Interfaceamento e Principais Características}

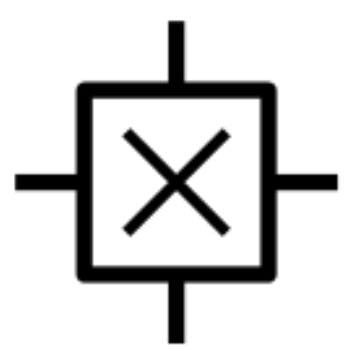

Figura 2.3.4 - Símbolo do Sensor de Efeito Hall em um circuito Fonte: Instituto Newton C. Braga

Usando configurações apropriadas de materiais, em conjuntos de placas, a tensão gerada pelo Efeito Hall pode ser multiplicada e, ao fazer isso, elaboram-se dispositivos sensores de campos magnéticos sensíveis e rápidos, com é o caso do Sensor Hall.

A grande vantagem do uso dos sensores de Efeito Hall é que eles podem ser fabricados com o próprio material usado na fabricação dos circuitos integrados. Isso significa a possibilidade de integrar circuitos amplificados e até mesmo conversores analógicos-digitais que permitem interfacear diretamente o sensor com microprocessadores e microcontroladores, tudo isso no próprio chip do sensor.

A seguir são listadas as principais vantagens que caracterizam o Sensor de Efeito Hall:

- $\quad$ Pode ser utilizado como chave

- $\quad$ Opera em frequências de até $100 \mathrm{kHz}$

- Custa menos que outras chaves mecânicas 
- $\quad$ Não tem as medidas prejudicadas devido ao "desprendimento" de algum contato, pois utilizam-se uma sequência de contatos em paralelo, ao invés de um único contato

- Não é afetado por impurezas, possibilitando que seja utilizado em condições extremas

- $\quad$ Pode ser utilizado como sensor de posição, deslocamento e proximidade.

- $\quad$ Pela sua velocidade de resposta, pela robustez e durabilidade os sensores de efeito Hall podem ser usados numa infinidade de aplicações e por isso podem ser encontrados numa infinidade de formatos e sensibilidades.

Os dispositivos de efeito Hall, contudo, possuem unidade de saída com capacidades muito baixas, da ordem de 10 a $20 \mathrm{~mA}$. Desse modo, eles não podem passar diretamente uma grande quantidade de carga elétrica. Para correntes mais altas, é necessário adicionar um transistor NPN de coletor aberto (com drenagem de corrente) à saída do sensor.

\section{Circuito}

Geralmente, um sensor de efeito Hall possui três pinos: VCC (alimentação), GND (terra) e VOUT (saída). A saída geralmente é do tipo coletor-aberto, e precisa de um resistor de pull-up, tendo uma resistência entre 1 e $10 \mathrm{k} \Omega$. O valor mínimo de resistência no circuito é função da corrente máxima de saída do sensor, isto significa que, para uma corrente máxima de $20 \mathrm{~mA}$ e uma tensão de $5 \mathrm{~V}$, tem-se uma resistência mínima de $250 \Omega$.

Em aplicações onde o consumo é prioridade, pode-se elevar o valor de resistência. No entanto deve-se observar que isto poderá induzir correntes de fuga para a 
terra, que ocorrem no condutor entre o resistor de pull-up e a saída do sensor. Estas correntes poderiam ser altas o suficiente para diminuir o valor de saída do sinal do sensor.

\section{Capacitores de Filtro}

É recomendado o uso de capacitores de $0,01 \mu \mathrm{F}$ para circuitos sem estabilização chopper, e $0,1 \mu \mathrm{F}$ para circuitos com este tipo de estabilização.

\section{Tempo de Inicialização}

Os sensores de efeito Hall levam menos de $1 \mu \mathrm{s}$ para inicializar sem estabilização chopper, enquanto que levam até $25 \mu$ s quando são empregados com este tipo de estabilização.

\section{4 - Microcontrolador}

O microcontrolador nada mais é que um pequeno computador, com um núcleo de processamento, memórias e periféricos programáveis, fabricado da mesma forma que outros componentes eletrônicos, como por exemplo, um transistor, um diodo, resistor etc. No entanto a eletrônica veio avançando e integrando cada vez mais componentes em uma área útil cada vez menor. Para o caso do microcontrolador, foi possível agregar memórias, conversores, transistores, multiplexadores, registradores tornando-o um componente bem atrativo.

O primeiro microcontrolador foi fabricado em 1971 pela Texas Instruments, batizado com o nome de TMS 1000, tornando-se disponível comercialmente em 1974 
(AUGARTEN, 1983). Foi o primeiro dispositivo eletrônico desenvolvido contendo, em um só chip, memória somente leitura (ROM - Read-Only Memory), memória para leitura e escrita (RAM - Random Access Memory), processador e relógio. Esse dispositivo foi desenvolvido tendo como mercado alvo os sistemas embarcados. A partir de então foram sendo desenvolvidos microcontroladores com outros dispositivos integrados, como por exemplo a memória PROM (Programmable Read-Only Memory) e a EPROM (Erasable Programmable Read-Only Memory) que usa a luz ultra-violeta para apagar a programação ali contida no dispositivo.

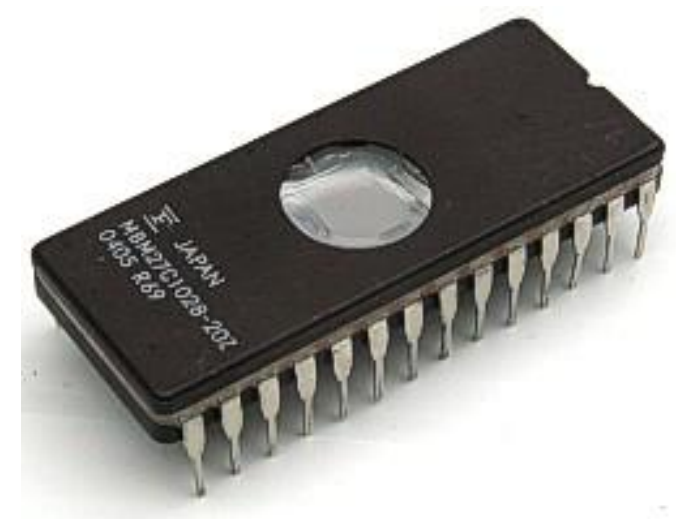

Figura 2.4.1 - Memória EPROM

Fonte: Fairchild Semiconductors

Dispositivos com a memória PROM foram bastante utilizados - comparados com a EPROM - por conta de seu custo reduzido de fabricação. A EPROM necessitava de uma janela de quartzo para a passagem de luz e uma carcaça cerâmica, tornando assim a fabricação desse dispositivo mais caro. Tecnicamente a PROM e a EPROM eram iguais, variando somente o invólucro do mesmo.

Já em 1993, com a introdução da memória EEPROM (Electrically Erasable PROM, também chamada de E2PROM), tornou o dispositivo ainda mais atrativo. Dessa forma poderia se usar um invólucro mais barato de ser fabricado - como o da PROM e dispensaria o uso de uma forma alternativa de apagar a memória. 
Hoje em dia o microcontrolador é amplamente utilizado em circuitos eletrônicos para o controle de processos e sistemas embarcados, por conta de sua versatilidade e baixo custo. Com ele é possível armazenar e editar um programa que é capaz de tomar decisões, executar rotinas de verificação, obter leituras de sensores e outros dispositivos, comandar relés etc. A operação do sistema baseia-se em operações lógicas e matemáticas, processadas pela Unidade Lógica Aritmética (ULA), que é o principal componente do micro- controlador. Todo o processamento de qualquer informação obtida pelos periféricos em conjunto com operações matemáticas é executado na ULA. Quanto mais poderosa essa unidade, mais avançado é considerado o microcontrolador. Alguns microcontroladores usam palavras de 4 bits, e operam em freqüências abaixo de $4 \mathrm{kHz}$, e normalmente pode ser programado para desligar alguns circuitos periféricos, de tal forma que se mantém a funcionalidade enquanto espera um evento específico como: a ativação de um sensor, um botão sendo pressionado, um pulso de algum botão etc. 


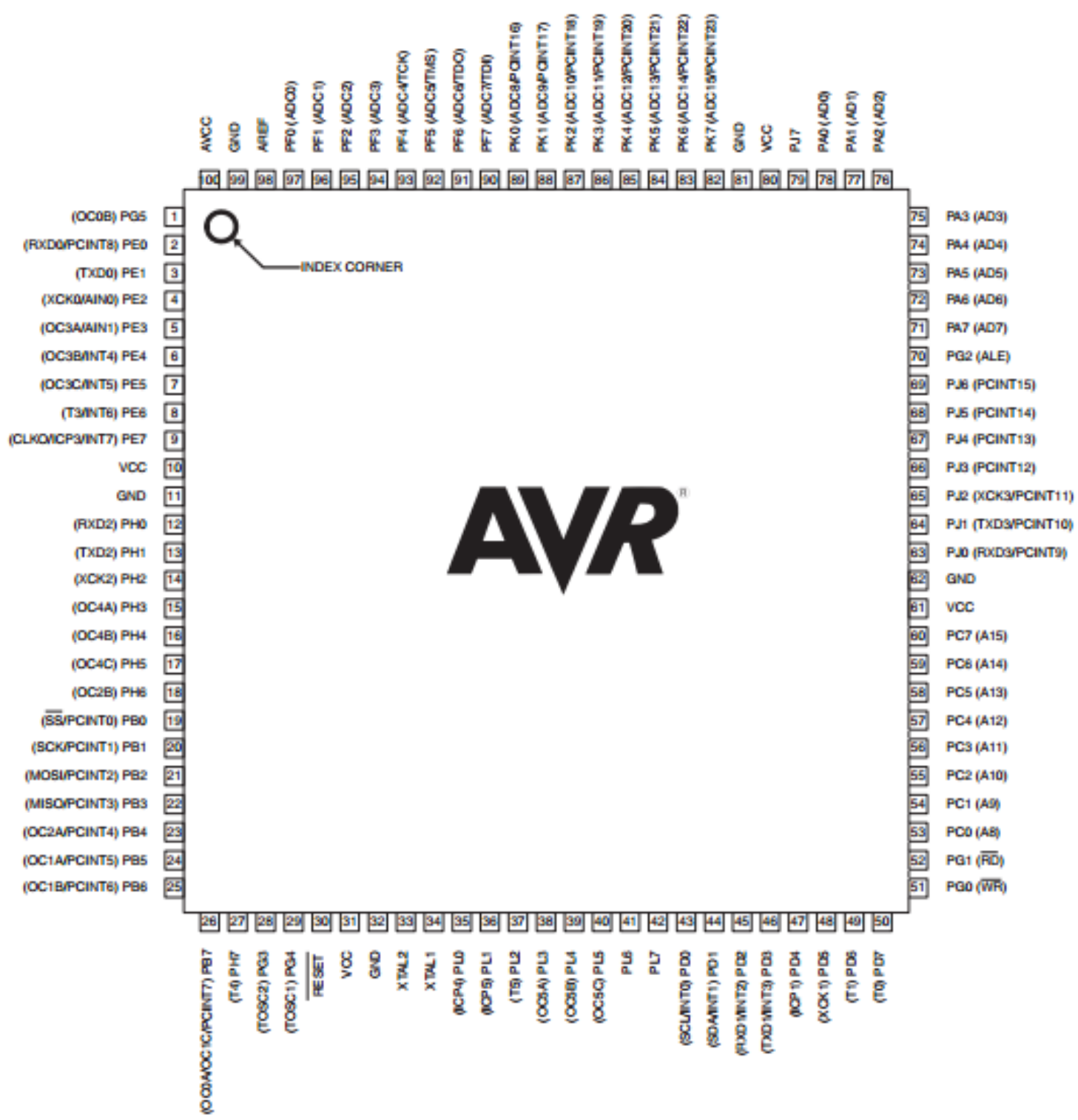

Figura 2.4.2 - Pinagem do microcontrolador ATmega2560

Fonte: Databook Microcontrolador ATmega Atmel Semicondutores

A programação desse componente é usualmente feita em "alto nível”, utilizando as linguagens de programação C, Pascal, Visual Basic e, com o auxílio de softwares compiladores, transforma-se em linguagem de máquina. É possível programar também em linguagem de "baixo nível”, conhecida como Assembly, que são as funções pré-definidas da arquitetura do microcontrolador. Porém esse tipo de linguagem exige que o programador tenha um conhecimento mais apurado dos componentes do microcontrolador como registradores e instruções. Normalmente acaba se tornando uma 
programação mais dificultosa e não muito usual, visto a necessidade de se ter que escrever uma função específica passo-a-passo, sendo que em alto nível, essa mesma função poderia ser escrita com não mais que cinco caracteres.

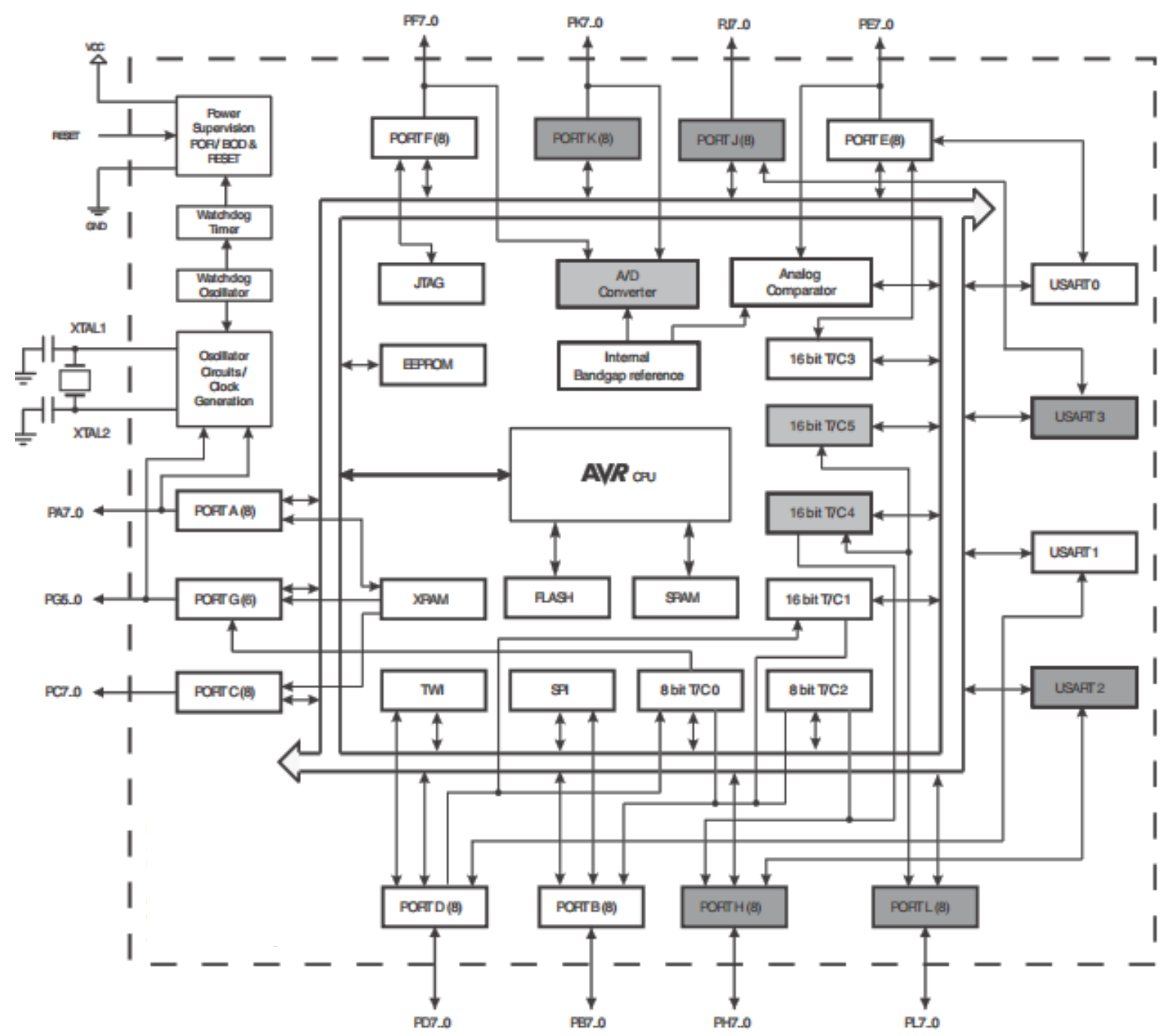

Figura 2.4.3 - Diagrama em blocos do Microcontrolador ATmega2560

Fonte: Databook Microcontrolador ATmega Atmel Semicondutores

Em contrapartida essa "tradução" da linguagem de alto nível para a de baixo nível normalmente acaba gerando programas pesados e lentos, com rotinas repetidas e, na maior parte dos casos, desnecessárias se comparadas com as escritas em Assembly, podendo impossibilitar a gravação do programa proposto por conta do limite de armazenamento, dependendo do modelo de microcontrolador escolhido. 
O microcontrolador que será usado no projeto detalhado adiante é o Atmega2560 que pode ser usado em diversos outros projetos, por conta de suas características e benefícios. São eles:

- Alta performance com baixo consumo;

- Arquitetura RISC com:

○ 135 Instruções. A maior parte delas necessitando de apenas um ciclo de relógio para executar;

- 32 registradores de 8 bits;

○ Operação 100\% estática;

○ Processamento de até 16 MIPS operado em 16MHz;

- Multiplicador On-chip em 2 ciclos.

- Memória não-volátil

- Memória Flash de 256Kbytes;

○ EEPROM de 4Kbytes;

○ Memória interna SRAM de 8Kbytes;

○ Ciclos de Leitura/Escrita: 10.000 na memória Flash e 100.000 na memória EEPROM;

- Armazenagem de dados por até 100 anos;

- Programação In-System;

- Operação de Leitura/Escrita ao mesmo tempo;

- Bloqueio/Desbloqueio via programação;

- Suporte à biblioteca $\mathrm{QTouch}{ }^{\circledR}$ da Atmel;

- Botões capacitivos, sliders e rodas;

- Até 64 canais para sensores;

- Interface JTAG 
- Escaneamento de acordo com o padrão JTAG;

○ Depuração em circuito;

○ Programação da memória flash, EEPROM, fusíveis e bits de bloqueio através da interface JTAG;

- Periféricos

○ Dois contadores de 8 bits com escalamento e comparações independentes;

○ Quatro contadores de 16 bits com escalonamento, comparações e capturas independentes;

- Contador em tempo real com oscilador separado;

○ Quatro canais PWM de 8 bits;

○ 12 canais PWM com resolução programável, de 2 a 16 bits;

- 16 canais ADC (Analogic Digital Converter - Conversor Analógico Digital);

○ Quatro portas seriais programáveis USART;

- Interface SPI (Serial Peripheral Interface) Mestre/Escravo;

○ Comunicação Serial de 2 vias, por byte orientado;

○ Contador "cão-de-guarda" com oscilador separado, no chip;

○ Comparador analógico;

○ Possibilidade de alteração de pino de Interrupção e Wake-up;

- Características Especiais do Microcontrolador

- Renicialização na energização e detecção de baixa tensão de alimentação;

○ Cristal Oscilador Interno Calibrado;

○ Interrupções Externas e Internas; 
- Seis modos de Sleep: Descanso, Redução de Ruído no ADC, Economia de Energia, Desligamento e Stand-by;

- Interface de Entrada e Saída

- 86 pinos programáveis de Entrada/Saída;

- Temperatura de Trabalho

○ De $-40^{\circ} \mathrm{C}$ a $85^{\circ} \mathrm{C}$;

- Baixo Consumo

○ Modo ativo: $1 \mathrm{MHz}$ a $1,8 \mathrm{~V}: 500 \mu \mathrm{A}$;

○ Modo desligado: $0,1 \mu \mathrm{A}$ a $1,8 \mathrm{~V}$;

- Frequências de Relógio em função da tensão de alimentação

○ 0 a $16 \mathrm{MHz} / 4,5 \mathrm{~V}$ a $5,5 \mathrm{~V}$; 


\section{3 - DESENVOLVIMENTO DO PROJETO}

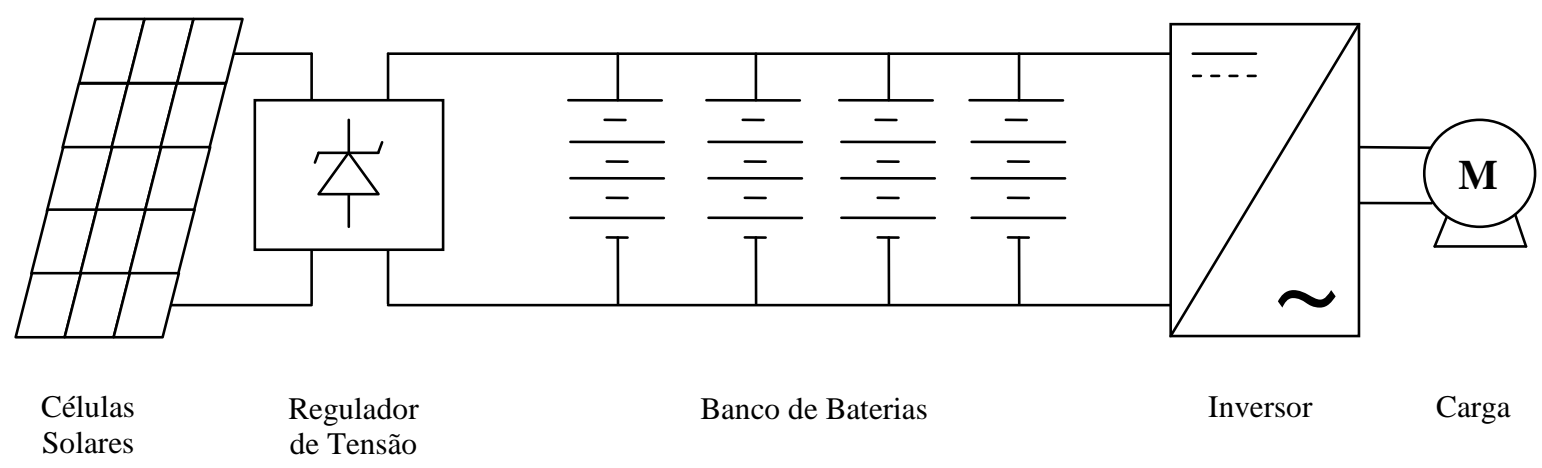

Figura 3.1 - Diagrama do Projeto

Fonte: Autor

Utilizando como matéria prima baterias automotivas, células solares e um retificador já é possível gerar energia elétrica. A solução apresentada não se aplica para equipamentos com grandes demandas, mas para alguns de uso essencial, como por exemplo, uma geladeira pequena, um transmissor de sinais, algumas luzes, um televisor etc.

Para o desenvolvimento do projeto, a carga final a ser usada como base é uma geladeira convencional, de aproximadamente 300L. Levando em consideração o refrigerador da Brastemp $\underline{B R F 36 G}$ de 330L, o mesmo tem uma potência média de 42,7W, resultando assim em um consumo de $1,026 \mathrm{kWh}$ ao dia, 30,8kWh por mês. Adotando-se que o rendimento do inversor é de aproximadamente 90\%, o sistema deverá fornecer pelo menos $1,14 \mathrm{kWh} /$ dia

Assumindo que as células solares são capazes de produzir energia elétrica por aproximadamente 5 horas por dia, logo as placas deverão ser de $228 \mathrm{~W}$. As células solares usadas são as KC130TM da Kyocera, capazes de fornecer até 130W de potência por unidade. No projeto foram usadas 3 células, resultando em uma potência máxima de $390 \mathrm{~W}$. 
Para o dimensionamento do banco de baterias, estas deverão suportar as cargas por pelo menos 4 dias sem geração (no caso sem luz solar, resultando assim na capacidade resultante de $4,56 \mathrm{kWh}$ para o período, e consequentemente uma capacidade de armazenamento de no mínimo 380Ah em $12 \mathrm{~V}$. No projeto foram usadas 4 baterias de 12V 180Ah, totalizando assim um armazenamento total de 720Ah.

Quanto ao monitoramento e tomada de decisões, está sendo usado o microcontrolador de 8 bits ATmega2560 da Atmel Corporation. Foi escolhido esse microcontrolador pelos seus recursos disponíveis como: conversor Analógico-Digital, para coleta dos dados de corrente e tensão; pinos de entrada e saída, para comando de abertura e fechamento dos relés; memória flash de $256 \mathrm{~KB}$; comunicação serial e também baixo custo, em torno de $\mathrm{R} \$ 150,00$ a unidade. Outros fatores decisivos na escolha foram: a familiarização com a tecnologia usada em projetos anteriores e facilidade na programação utilizando-se da plataforma open-source Arduino.

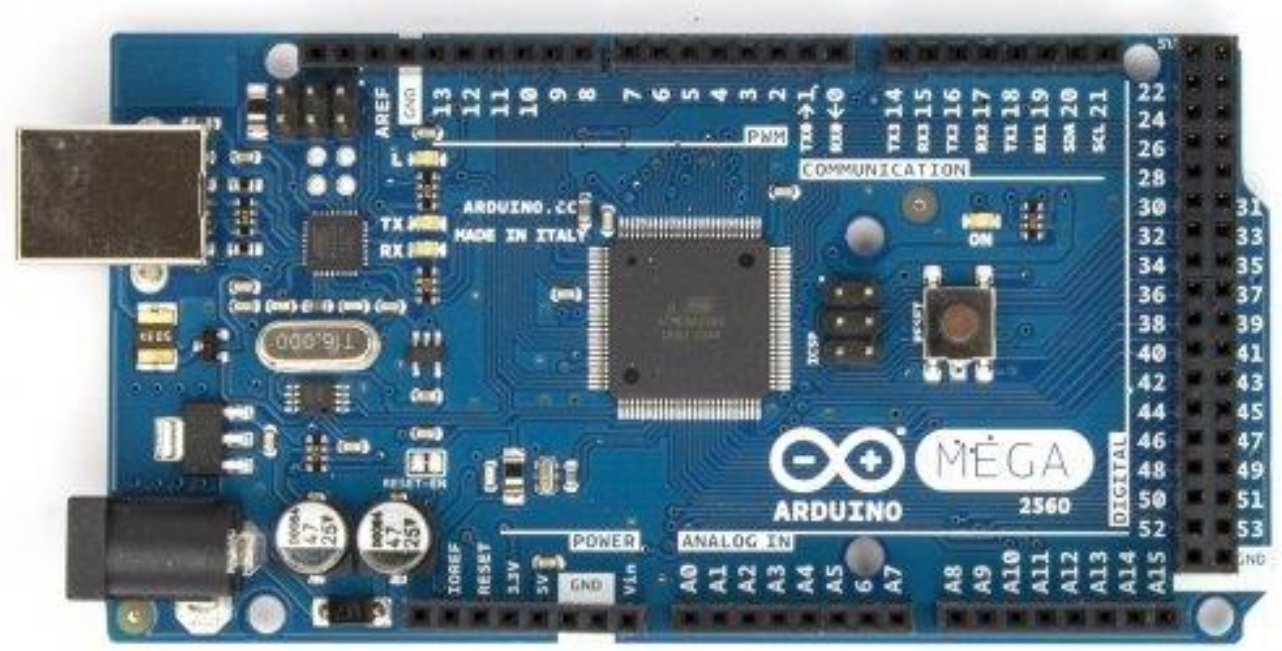

Figura 3.2 - Arduino MEGA 2560 com microcontrolador ATmega2560

Fonte: Sítio www.arduino.cc 
A tomada de leitura de data e hora no programa é através de um CI relógio, o DS1302, o qual se comunica serialmente com o microcontrolador através do protocolo SPI. Estão sendo usados também sensores de "efeito hall" ACS756-050 da Allegro Microsystems Inc. para a leitura das correntes das células solares, baterias e carga. A corrente a ser lida flui por dois terminais desse circuito integrado, gerando um campo magnético e convertendo para um valor proporcional de tensão. 

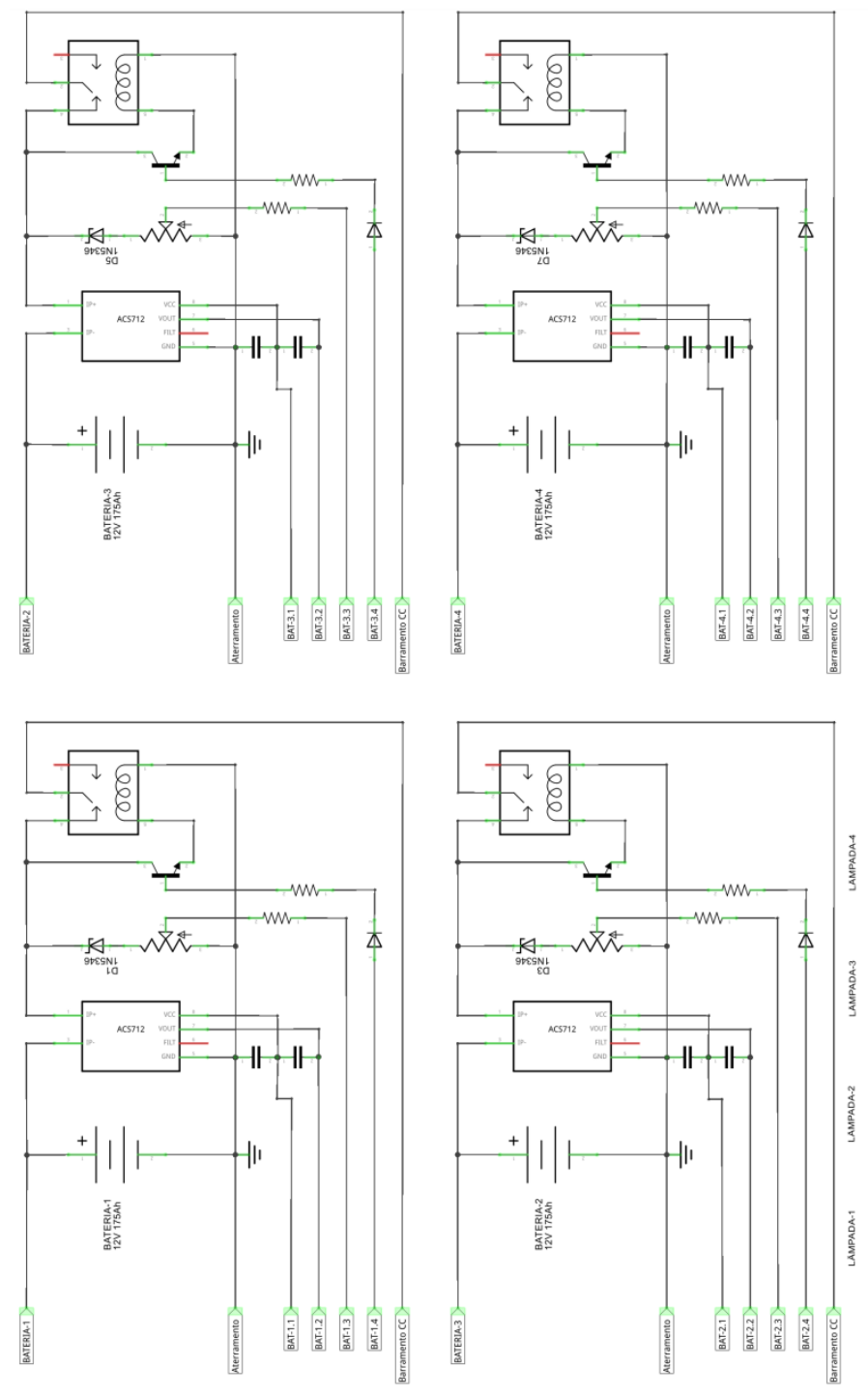

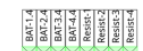
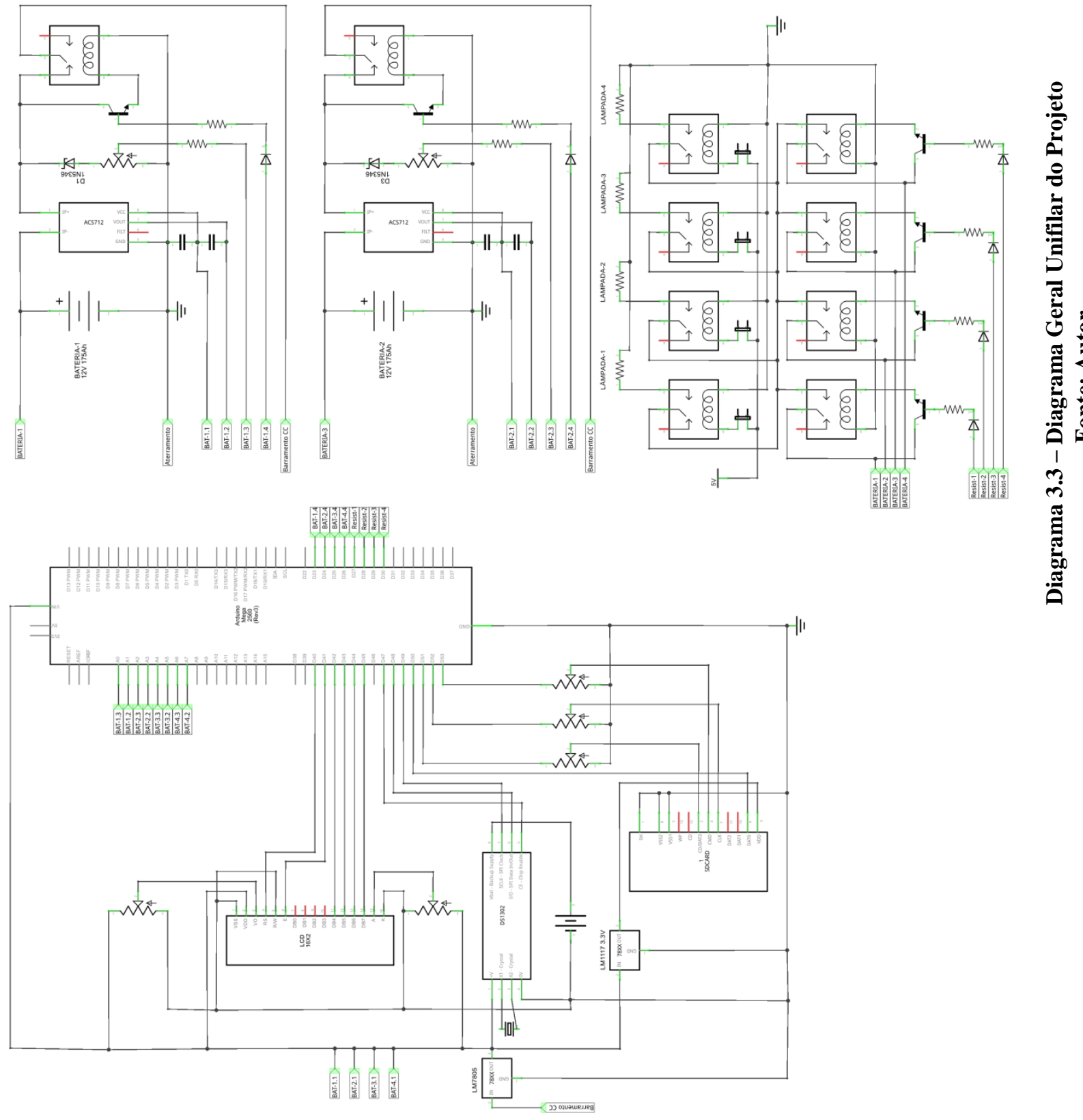


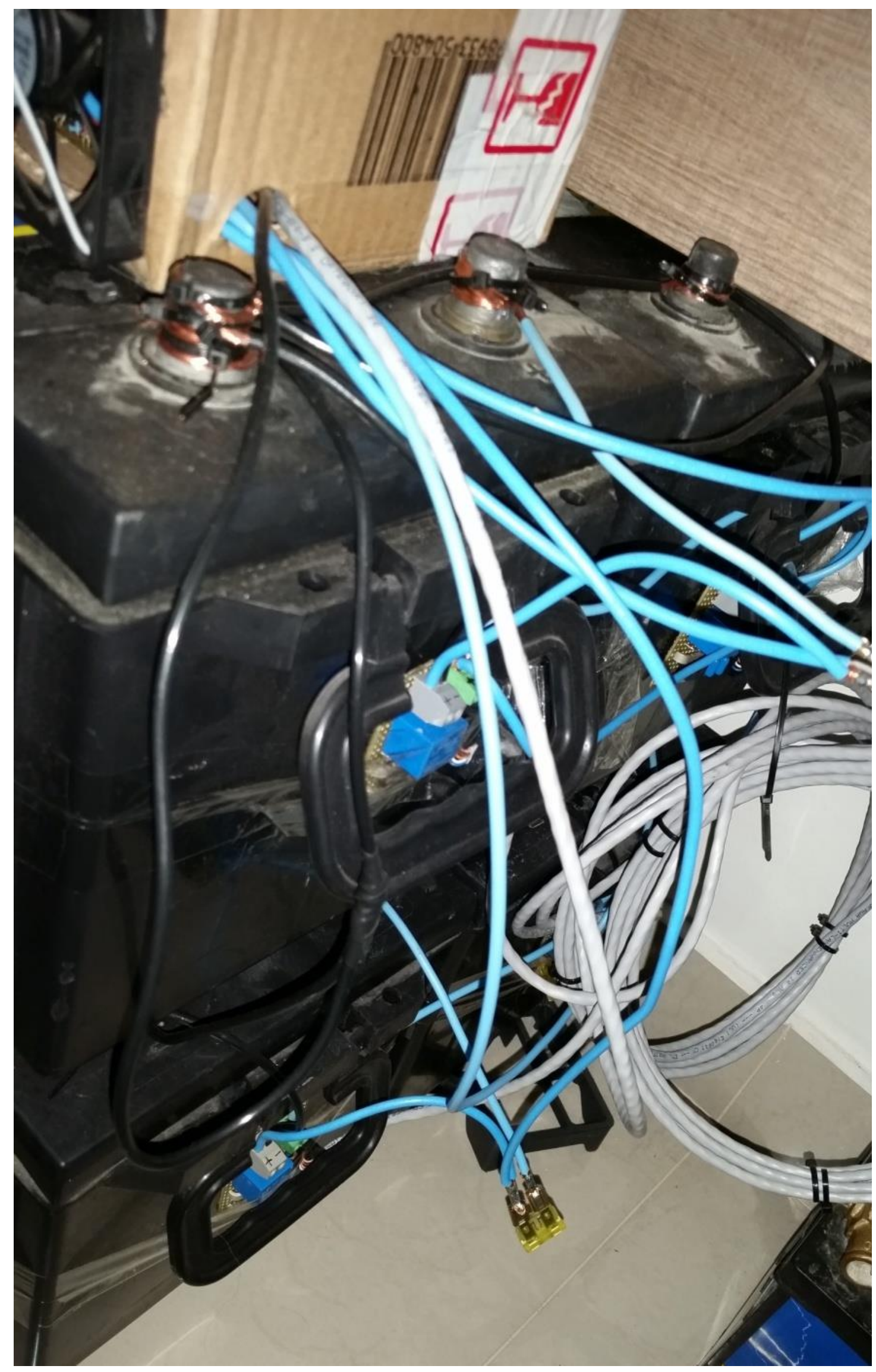

Figura 3.4 - Baterias com o circuito de Medição Fonte: Autor 


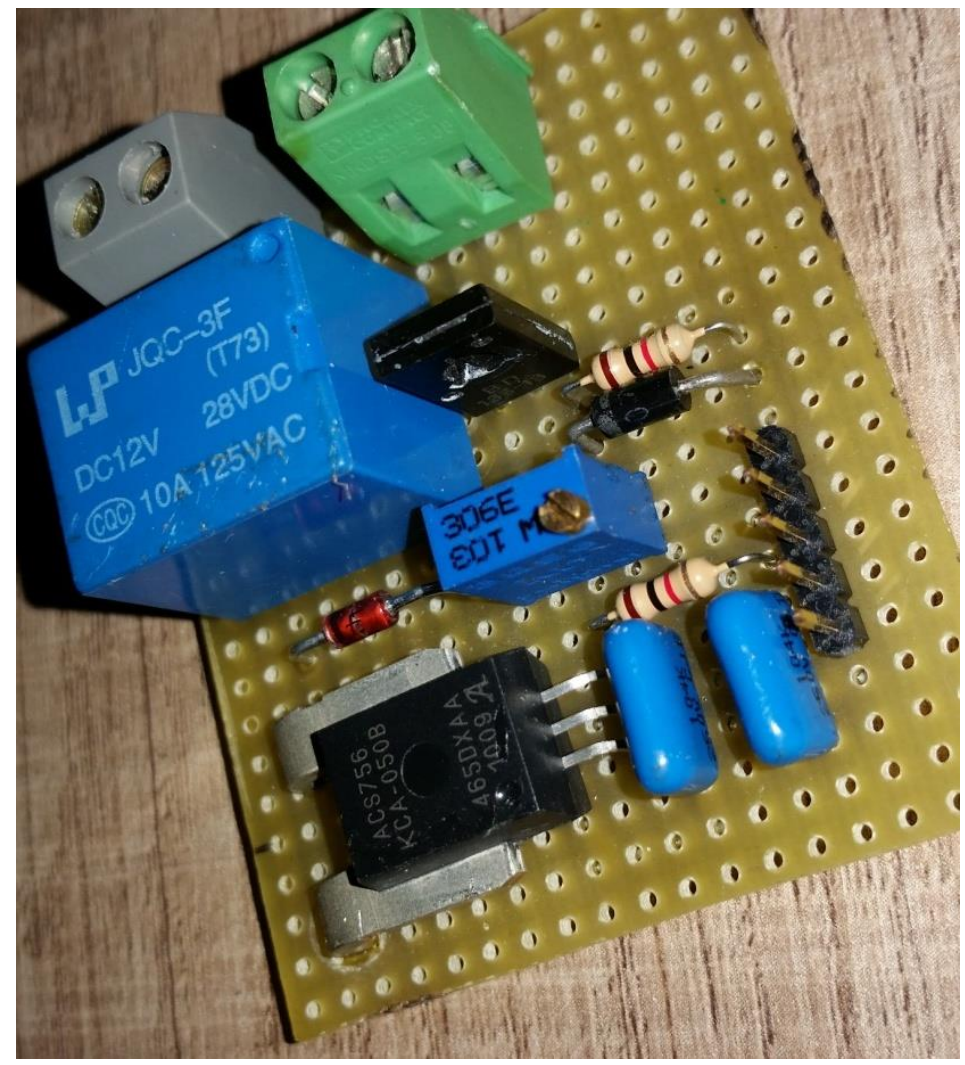

Figura 3.5 - Circuito de Medição da Bateria Fonte: Autor

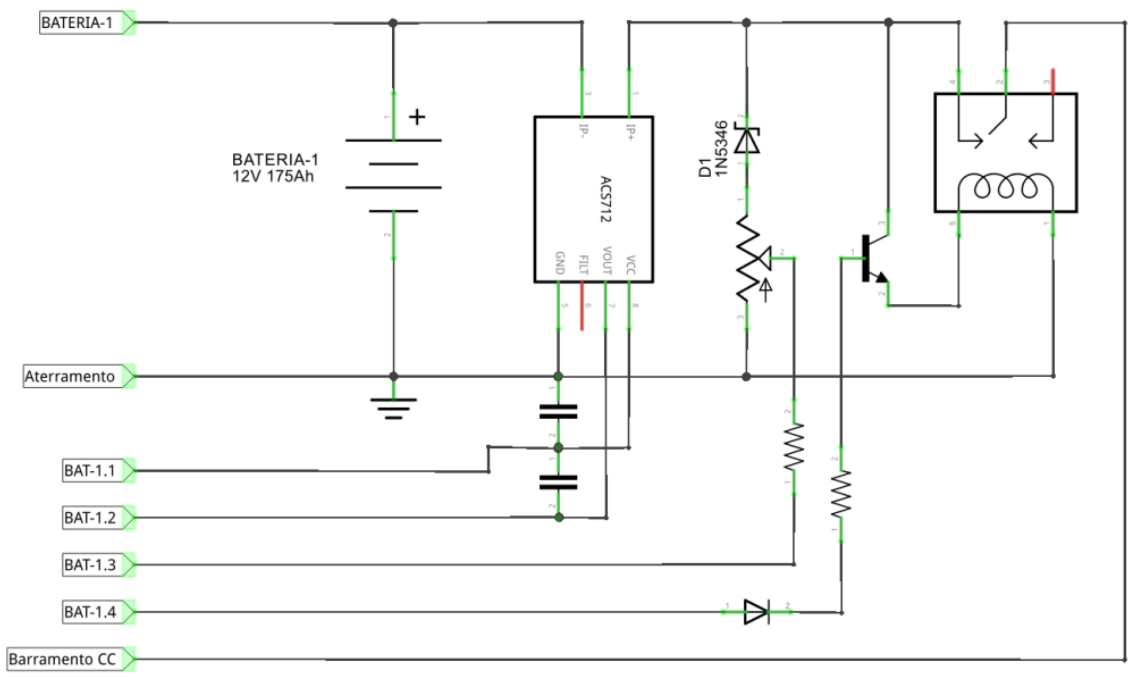

Figura 3.6 - Diagrama do Circuito de Medição da Bateria Fonte: Autor 
Para o banco de baterias estão sendo usadas 4 baterias no total, de 170Ah cada. Adotando que cada bateria usada pode fornecer aproximadamente metade de sua capacidade nominal, a capacidade final do banco de baterias fica sendo em torno de 680Ah. Baseando-se nesses números anteriores, a autonomia do sistema é de aproximadamente 34 horas. No entanto sabe-se que, por conta das baterias já terem sido usadas para alguma outra finalidade, elas tem capacidade reduzida de fornecimento e armazenamento de energia.

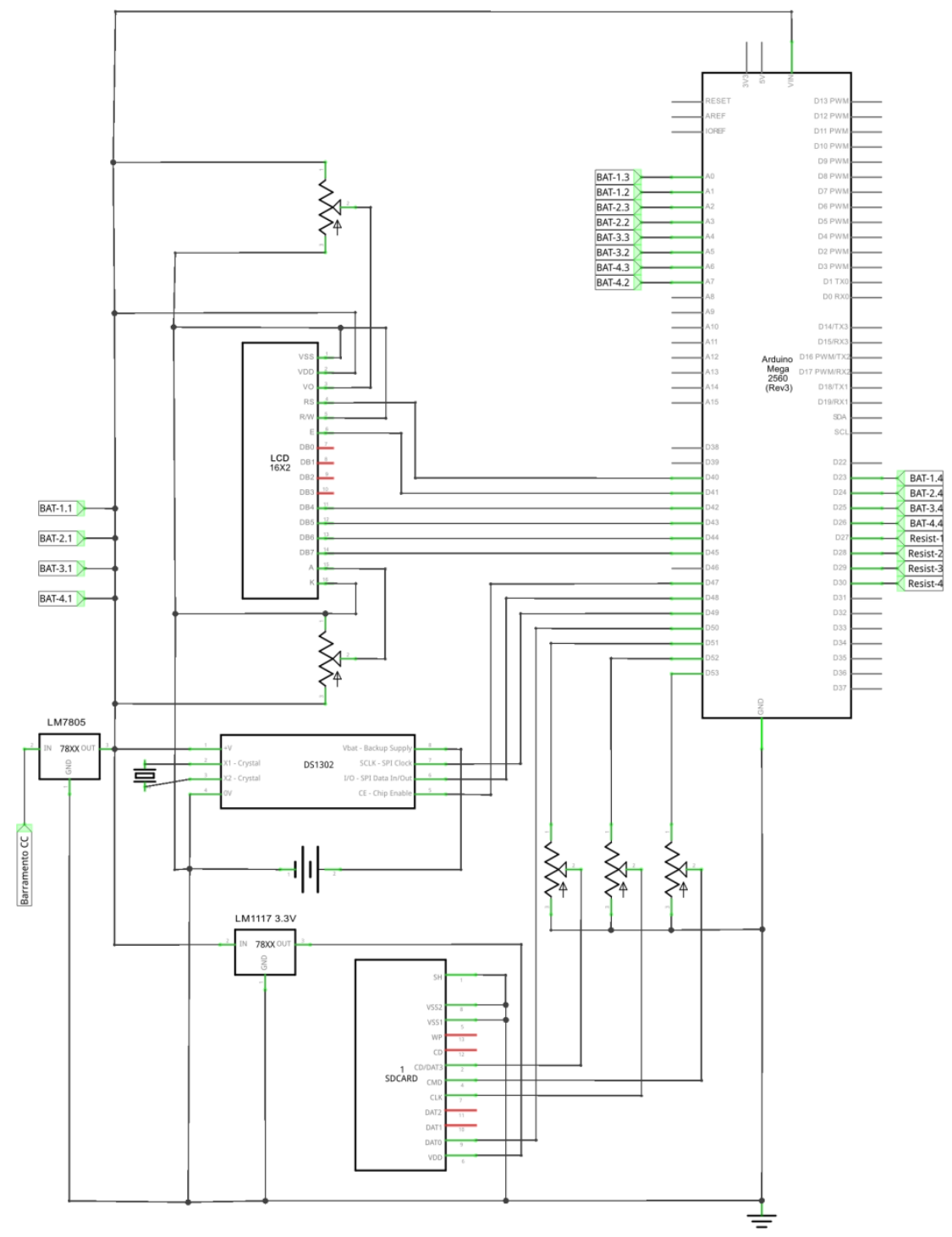

Figura 3.7 - Diagrama do Projeto com LCD, RTC DS1302, Cartão SD e o Arduino Mega 2560 Fonte: Autor 


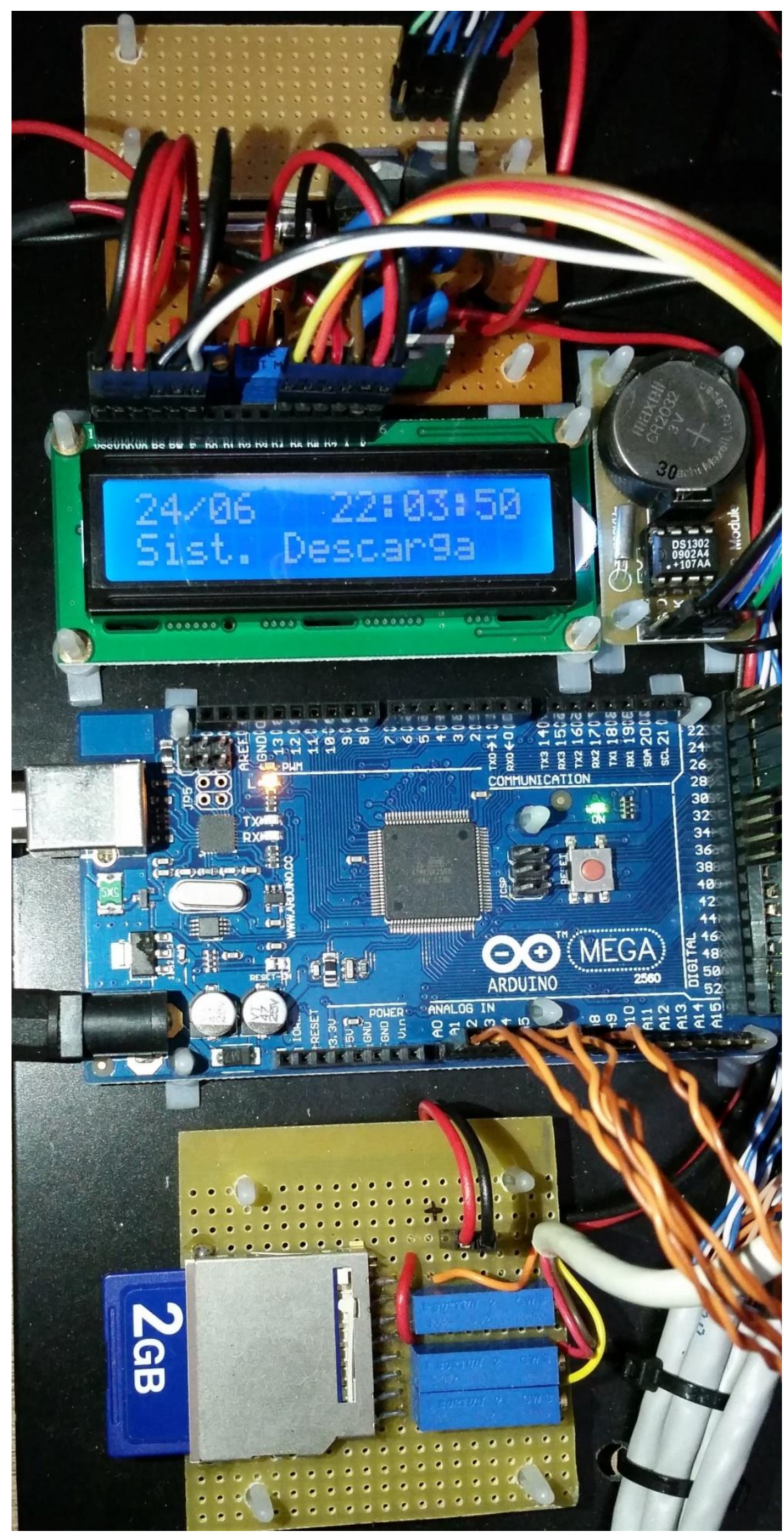

Figura 3.8 - Projeto com LCD, RTC DS1302, Cartão SD e o Arduino Mega 2560 Fonte: Autor 
Foi desenvolvido um programa, em linguagem $\mathrm{C}$, para trabalhar no mícrocontrolador que tem a função de avaliar periodicamente o estado das baterias. $\mathrm{O}$ programa informa ao usuário qual bateria está sendo lida naquele momento através de um display LCD 16x2, que reporta com mensagens cada etapa da medição. O programa inclusive é capaz de isolar uma ou mais baterias no sistema, a fim de evitar uma sobrecarga na bateria ou ainda retirar uma bateria defeituosa, para que não seja uma carga adicional e acabe prejudicando o sistema como um todo.

Primeiramente o programa avalia se o sistema está em Carregamento ou em Descarga através do uso de um LDR, ligado a um dos pinos de Entrada/Saída do microcontrolador. A resistência do LDR varia em função da intensidade luminosa sobre o componente, avaliando se existe luz suficiente para a geração de energia ou não. A partir de então se inicia uma parte do diagnóstico das baterias.

\section{1 - Sistema em Carregamento}

Entende-se que, com o sistema em Carregamento, a energia fornecida pelas células solares é superior ao consumido pela carga. Dessa forma é possível isolar uma das baterias - usando um relé de interface - para se obter a tensão da mesma em circuito aberto, e avaliar se está ou não dentro dos limites esperados. Para uma bateria de 12V ser considerada boa, ela tem que estar com sua tensão entre $11,5 \mathrm{~V}$ e $14 \mathrm{~V}$. Foi utilizado um diodo Zener 1N5346, um potenciômetro multi-voltas de 1,0K $\Omega$ para o ajuste fino, conectado ao pino de Entrada Analógica do ATmega2560. Com o uso do Conversor Analógico-Digital (DAC) do microcontrolador foi possível determinar se a bateria se encontra entre os valores acima citados ou não. Se o valor total lido está entre 11,5V e $14 \mathrm{~V}$, o sistema avisa o usuário através de um display LCD 16x2 de que a bateria está "Carregando" e coloca novamente a bateria no barramento do sistema. Caso contrário 
avisa ao usuário de que a bateria está "Carregada" e mantém a bateria fora do sistema até a nova rodada de leitura.

\section{2 - Sistema em Descarga}

Quando o sistema está em Descarga, as baterias estão em uso e estão drenando sua energia para a carga. A rotina de medição é semelhante à realizada com o sistema em Carregamento, com a diferença da tensão limite superior ser de $15 \mathrm{~V}$ e do uso de um contador de defeitos. Se a tensão medida esteja fora dos valores estabelecidos anteriormente, o sistema avisa o usuário através do LCD de que a bateria está em "Dúvida", e retira temporariamente a bateria do barramento. Acaso a tensão medida na bateria esteja fora dos limites por mais de 10 vezes consecutivas, o sistema isola definitivamente a bateria do restante do sistema e avisa o usuário de que a bateria está com "Defeito".

\section{3 - Medição da Resistência Interna da Bateria}

Foi desenvolvida também uma rotina de testes para as baterias a fim de se determinar a resistência interna das mesmas, colocando uma carga resistiva em paralelo com cada bateria. Esses testes somente são executados se o sistema estiver em Carregamento.

O objetivo principal de se obter a resistência interna da bateria é justamente para avaliar se alguma bateria do banco está prejudicando o sistema como:

- Carga para o sistema;

- Armazenagem de energia deficiente;

- Valor de tensão final fora do esperado. 
Para tanto foi montado um circuito com três lâmpadas dicróicas de 12V/50W ligadas em paralelo e produzindo assim uma resistência equivalente de aproximadamente $1,0 \Omega$. O programa desconecta do barramento a bateria a ser testada e conecta-a o circuito resistivo através de relés de interface, mantendo-o assim por aproximadamente 30 minutos. São tomadas leituras de corrente e tensão da bateria logo após o início e ao final do teste, a fim de se calcular a resistência interna. Se a tensão final da bateria estiver abaixo de $11,5 \mathrm{~V}$, o programa assinala a bateria como defeituosa e mantém a mesma isolada do sistema.

$$
R I_{B A T X}=\frac{V_{x i}-V_{x f}}{I_{x i}-I_{x f}} \quad \text { Sendo "x" a bateria em questão. }
$$

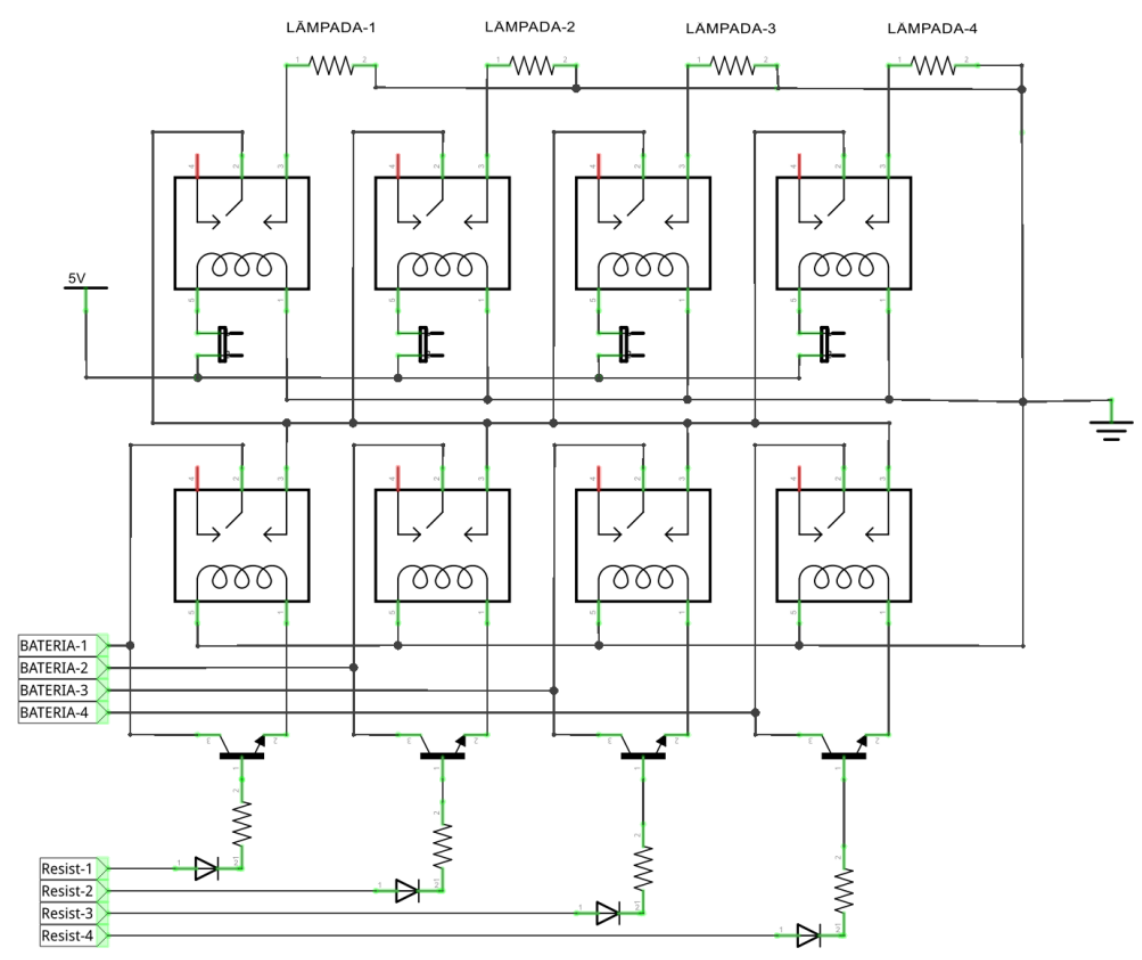

Figura 3.9 - Diagrama do Circuito Resistivo de Teste Fonte: Autor 


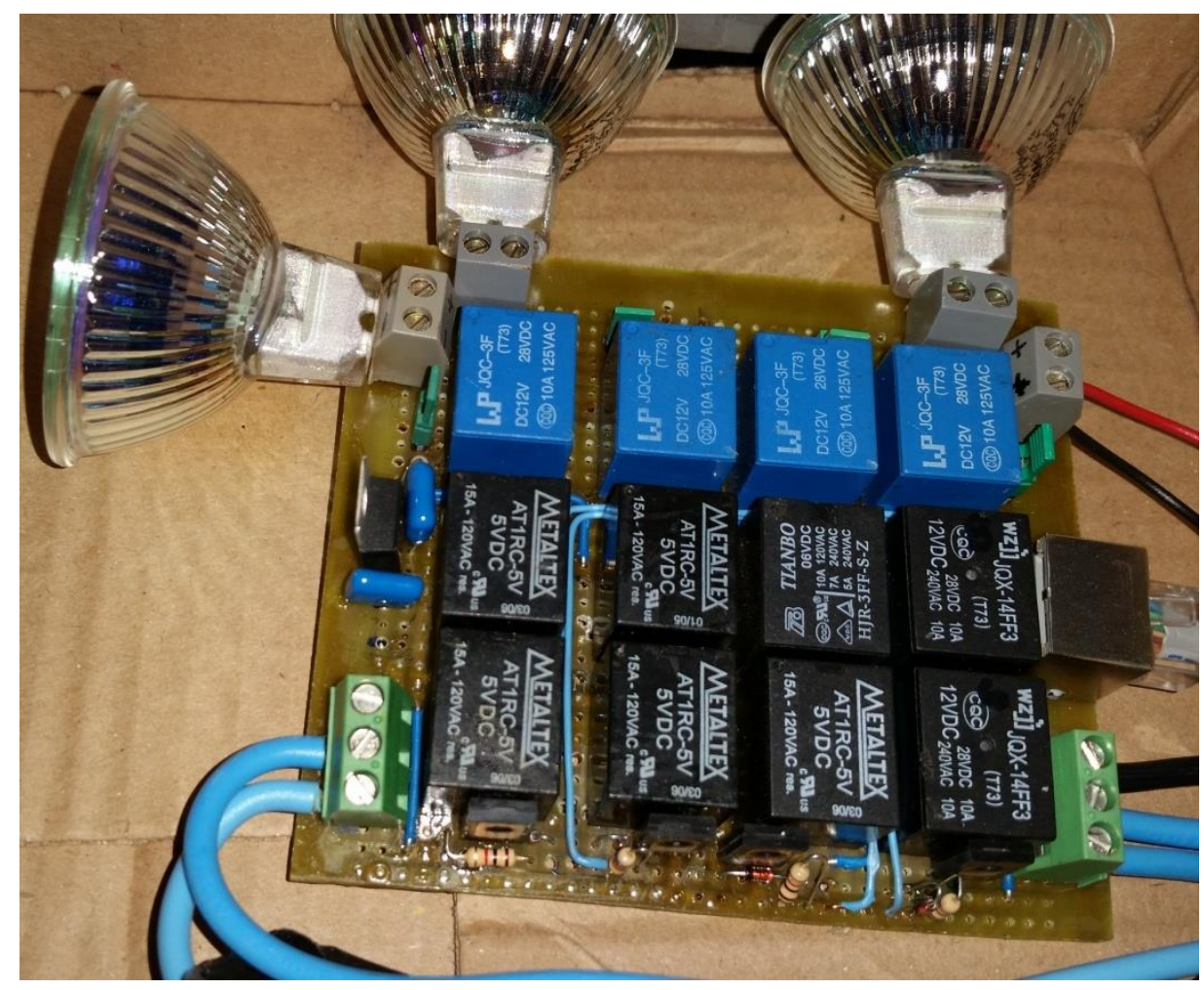

Figura 3.10 - Circuito Resistivo de Teste, com lâmpadas dicróicas Fonte: Autor

\section{4 - Armazenagem dos dados}

Todos os dados lidos das células, baterias e carga, bem como data e hora são armazenados em uma memória EEPROM, a fim de possibilitar análises mais criteriosas sobre eficiência e vida útil das baterias, eficiência das células solares, comportamento da carga durante diferentes estações do ano, transição entre dia/noite, clima nublado/chuvoso/ensolarado, dentre outros. A memória escolhida foi o cartão SD (Secure Card), por possuir grande capacidade de armazenamento e ser facilmente encontrado em lojas de eletrônicos ou informática. 


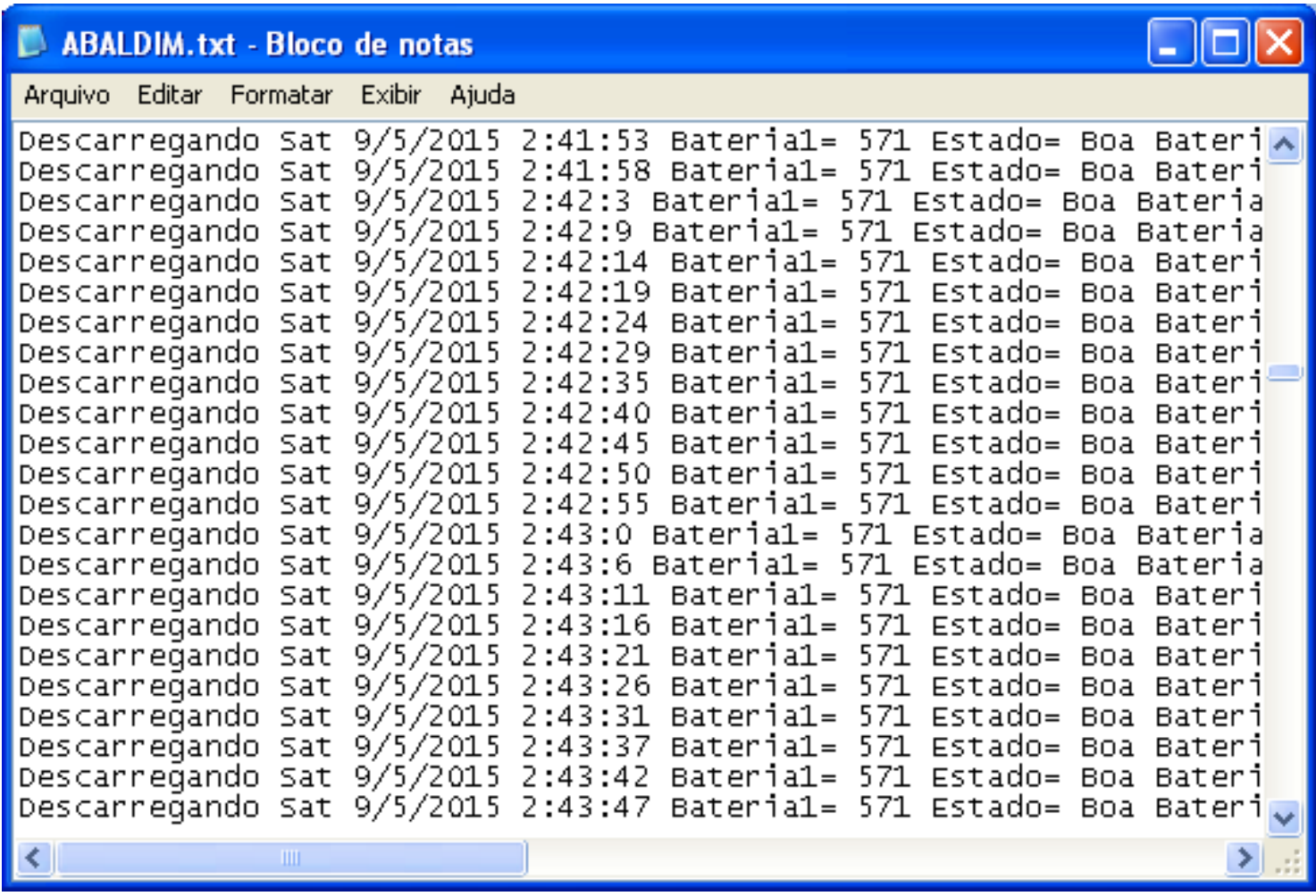

Figura 3.11 - Exemplo de Arquivo de Saída com as tensões das Baterias Fonte: Autor

\section{RINTBAT.txt - Bloco de notas}

Arquivo Editar Formatar Exibir Ajuda

wed $6 / 5 / 2015$ 14:32:3 Baterial= 40 ohm Bateria2= -1 ohm Bateria3= 1 Thr $7 / 5 / 2015$ 14:31:59 Baterial= -1 ohm Bateria2= -24 ohm Bateria3= Fri 8/5/2015 14:32:2 Baterial= -1 ohm Bateria2= -1 ohm Bateria3= -1 sat $9 / 5 / 2015$ 14:31:59 Baterial= -1 ohm Bateria2= -1 ohm Bateria3= Sun 10/5/2015 14:31:58 Baterjal= -1 ohm Bateria2= -1 ohm Bateria3= wed $13 / 5 / 2015$ 22:38:16 Baterial= 0 ohm Bateria2= -1 ohm Bateria3= $\mathrm{C}$ wed 13/5/2015 22:44:29 Baterjal= -1 ohm Baterja2= 25 ohm Baterja3= Thr 14/5/2015 21:4:31 Baterial= -91 ohm Bateria2= 38 ohm Bateria3= Thr 14/5/2015 21:58:59 Baterial= -1 ohm Bateria2= 62 ohm Bateria3=

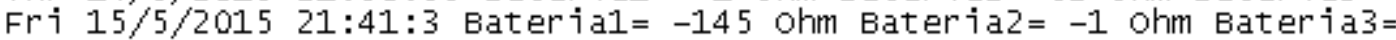
Fri 15/5/2015 23:18:0 Baterial= -96 ohm Bateria2=134 ohm Bateria3= sat 16/5/2015 5:2:6 Baterial= -134 ohm Bateria2=154 ohm Bateria3= sat 16/5/2015 11:2:6 Baterial= -60 ohm Bateria2= -133 ohm Bateria3= sat $16 / 5 / 2015$ 17:2:2 Baterial= -1 ohm Bateria2= -1 ohm Bateria3= 21 sat 16/5/2015 23:2:3 Baterial= 117 ohm Bateria2=131 ohm Bateria3= Sun 17/5/2015 5:2:1 Baterial= 116 ohm Bateria2= -1 ohm Bateria3=17 Sun 17/5/2015 11:2:4 Baterial= 117 ohm Bateria2= -63 ohm Bateria3= Sun 17/5/2015 17:2:4 Baterial= 63 ohm Bateria2= -130 ohm Bateria3= Sun 17/5/2015 23:2:3 Baterial= -123 ohm Bateria2= -67 ohm Bateria3= Mon 18/5/2015 5:2:3 Baterial= 69 ohm Bateria2= -75 ohm Bateria3= $1 \varepsilon$

Figura 3.12 - Exemplo de Arquivo de Saída com medições de Resistência Interna das Baterias Fonte: Autor 
Para cada "rodada de leitura" são armazenados: Estado do sistema (Carregando ou Descarregando), data e hora, a tensão e o estado (carregando, carregada ou defeito) de cada bateria. Sendo assim são necessários 155 bytes a cada 5 minutos. Foram armazenados também os dados de resistência interna das baterias, o qual utiliza 95 bytes a cada teste. Utilizando uma memória de 2,0GB, se tem uma autonomia de armazenamento de aproximadamente 130 anos. 


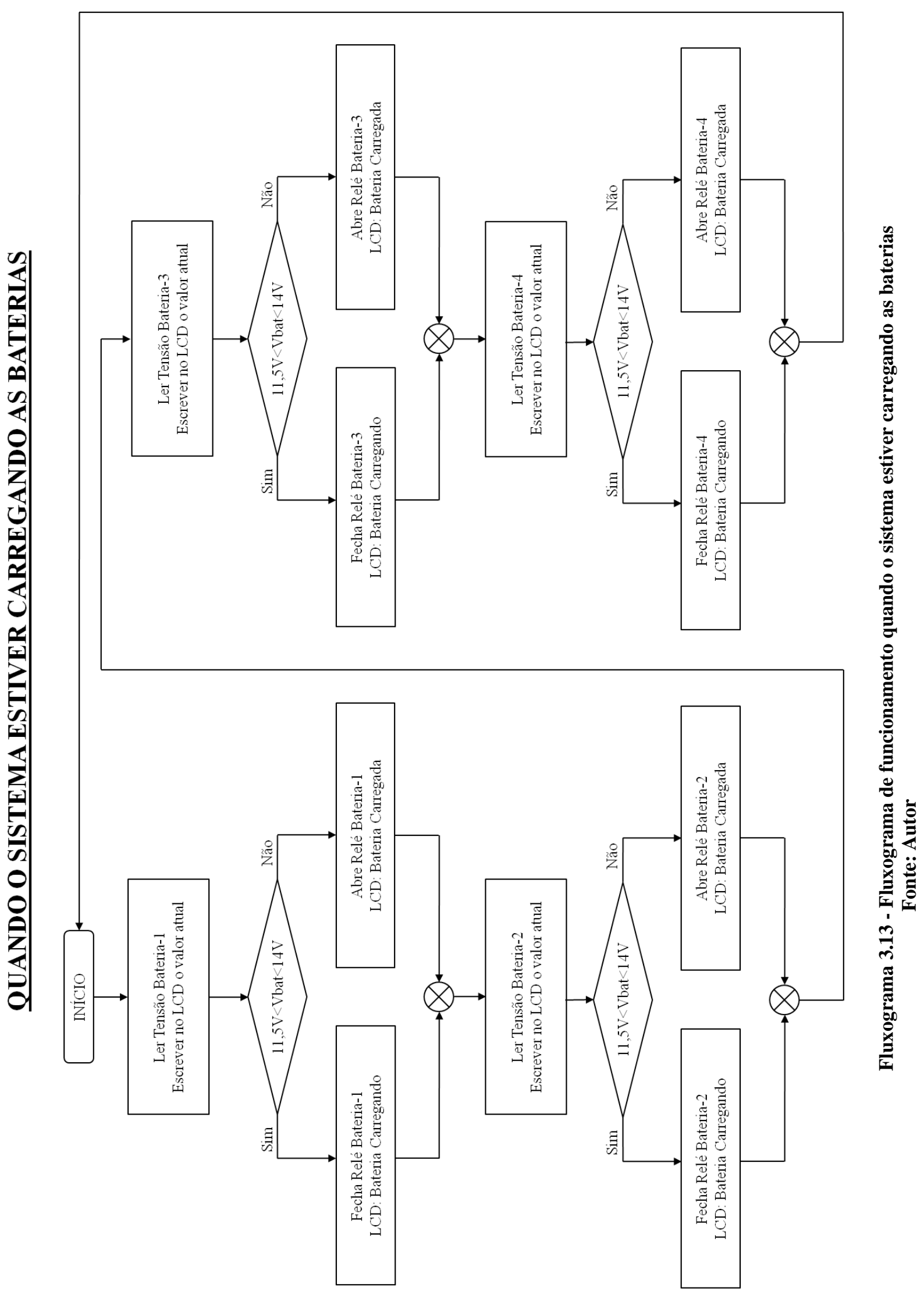




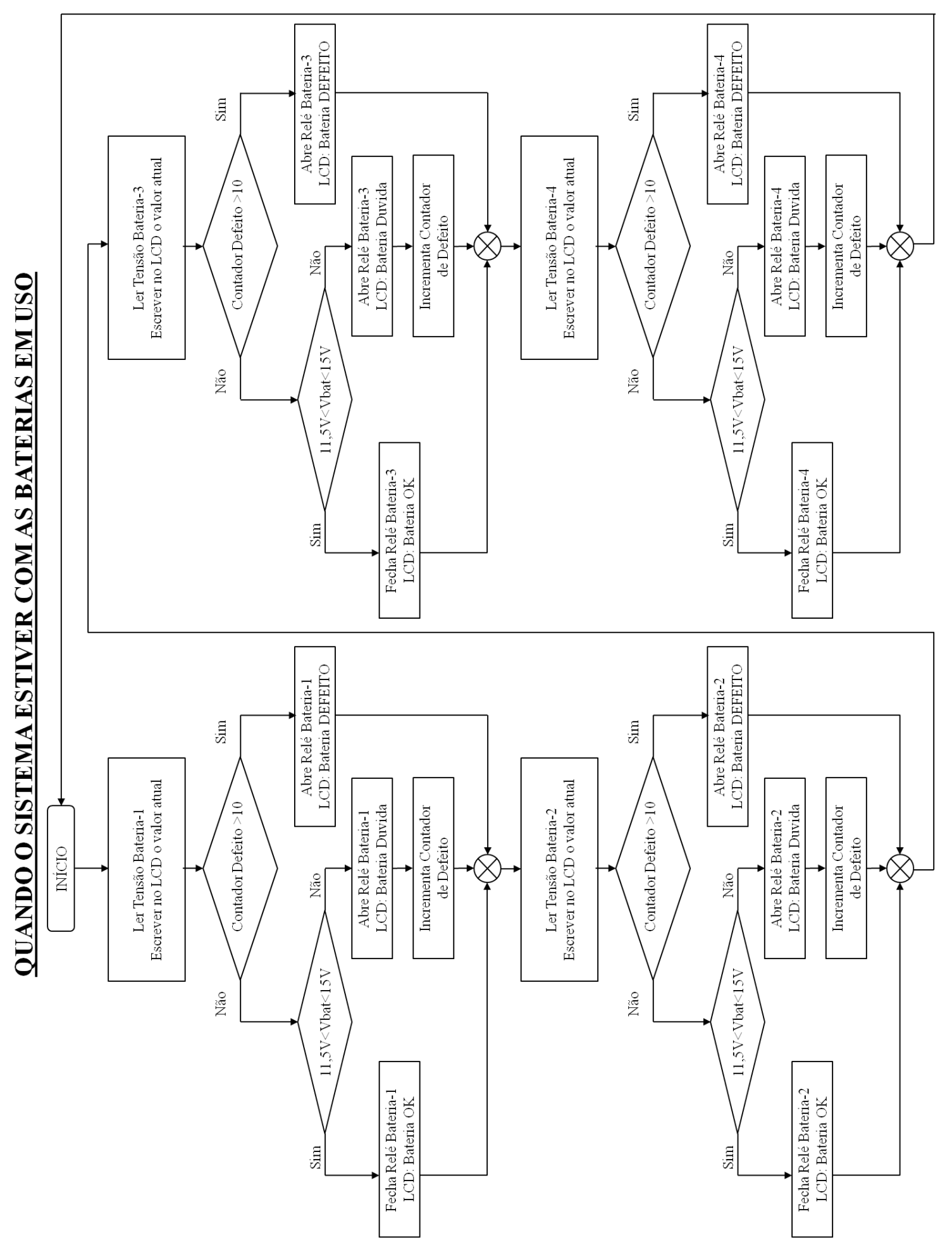

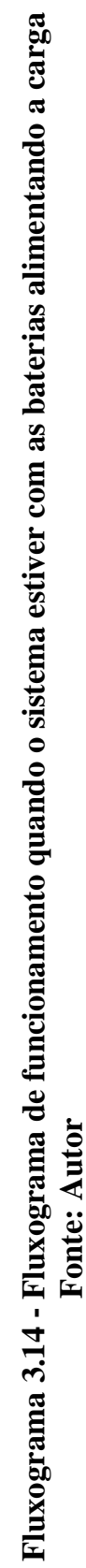




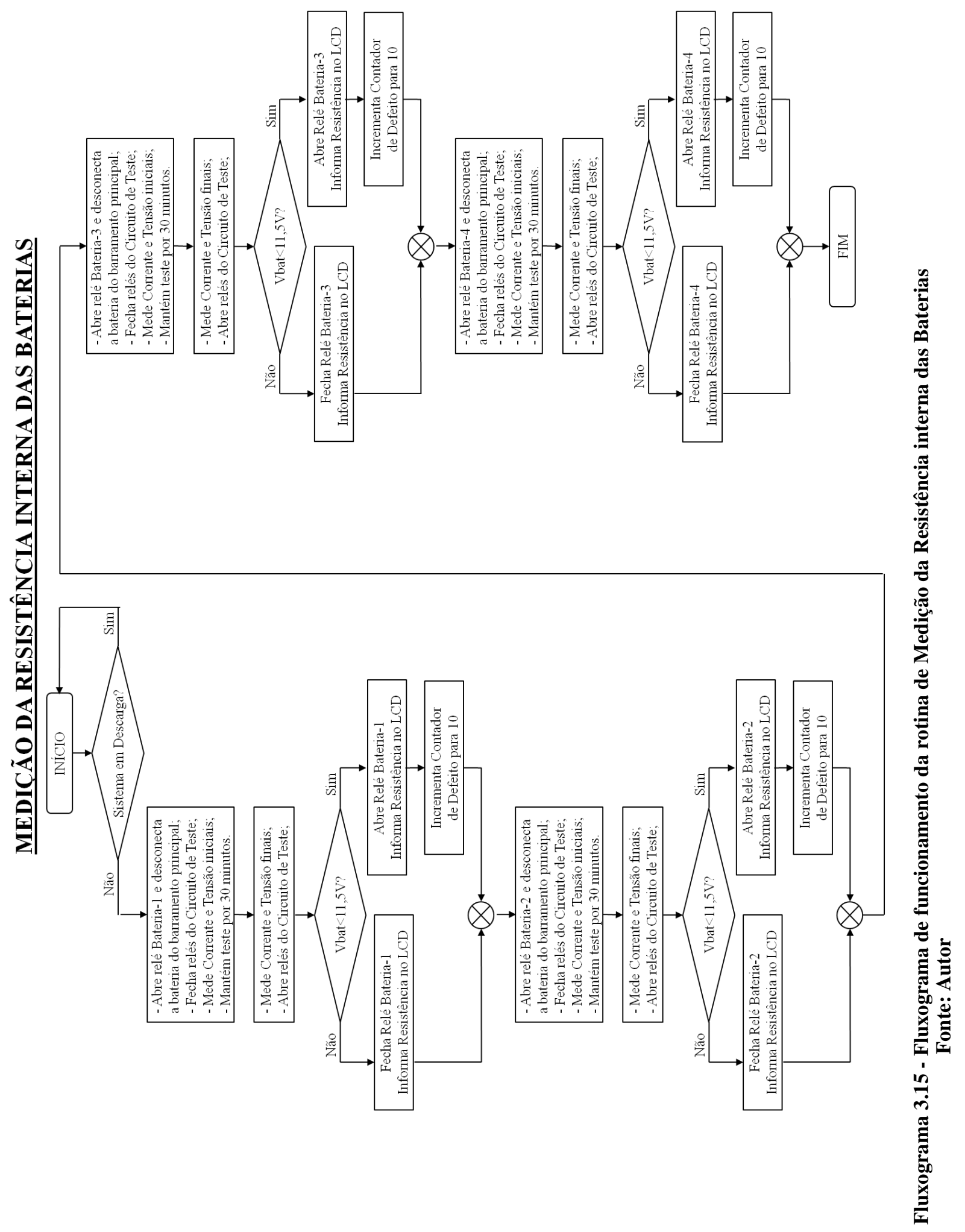




\section{4 - RESULTADOS}

O sistema todo foi montado inicialmente em bancada para ajustes e testes. Durante esse período de testes foi possível capturar os dados das baterias e provar o funcionamento dos sistemas todos integrados. Os gráficos abaixo mostram a variação de tensão lida nas baterias por amostragens. Cada amostragem tem um intervalo de duração de aproximadamente 10 segundos entre cada leitura.

No gráfico abaixo mostra a descarga das baterias usando inicialmente uma carga pequena na saída, de $40 \mathrm{~W}$ apenas. Depois foi colocada outra carga maior em paralelo, de aproximadamente 500W.

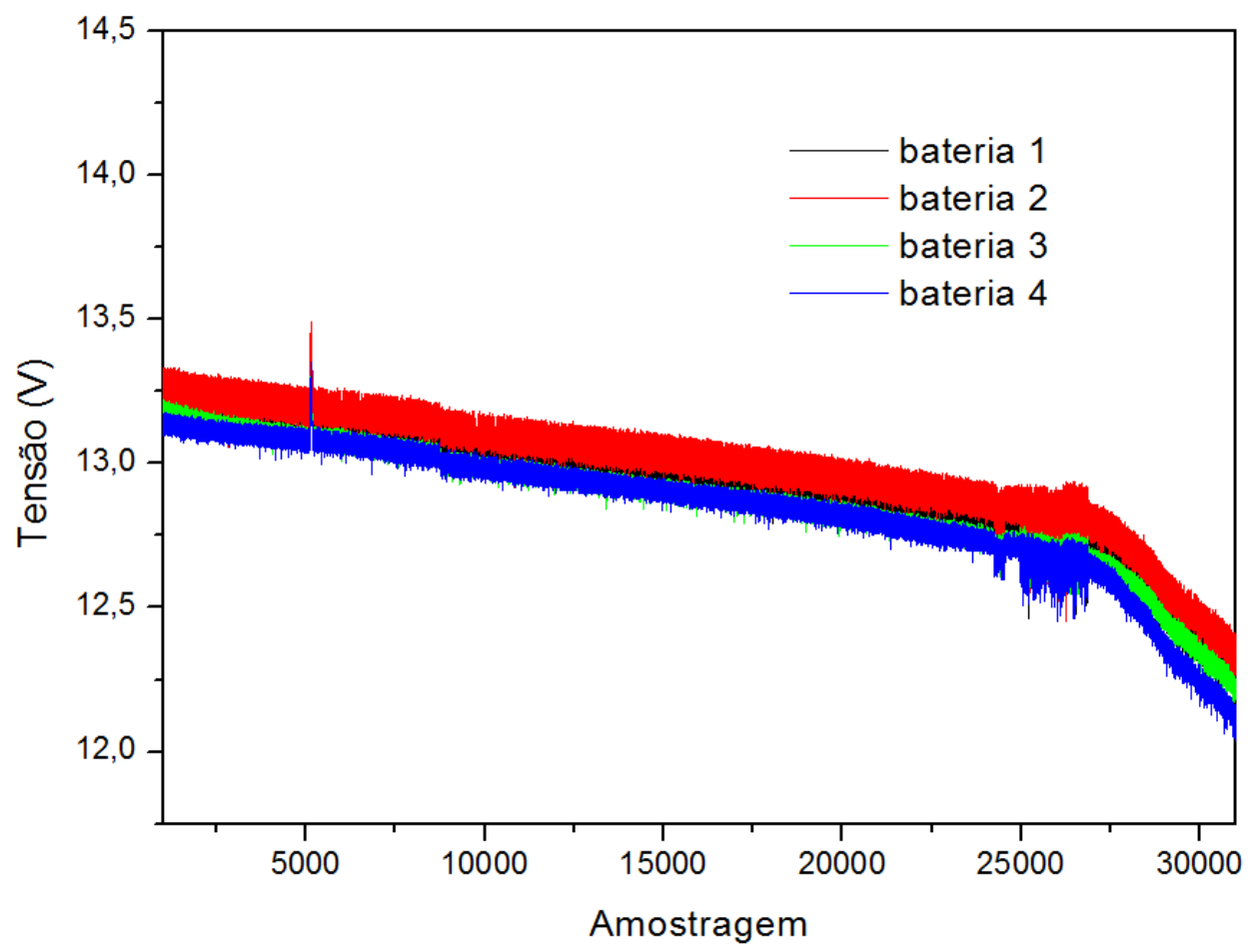

Gráfico 4.1 - Teste de Descarregamento das Baterias Fonte: Autor

Após as baterias estarem completamente descarregadas, o retificador foi ligado novamente a fim de carregar as baterias novamente. 


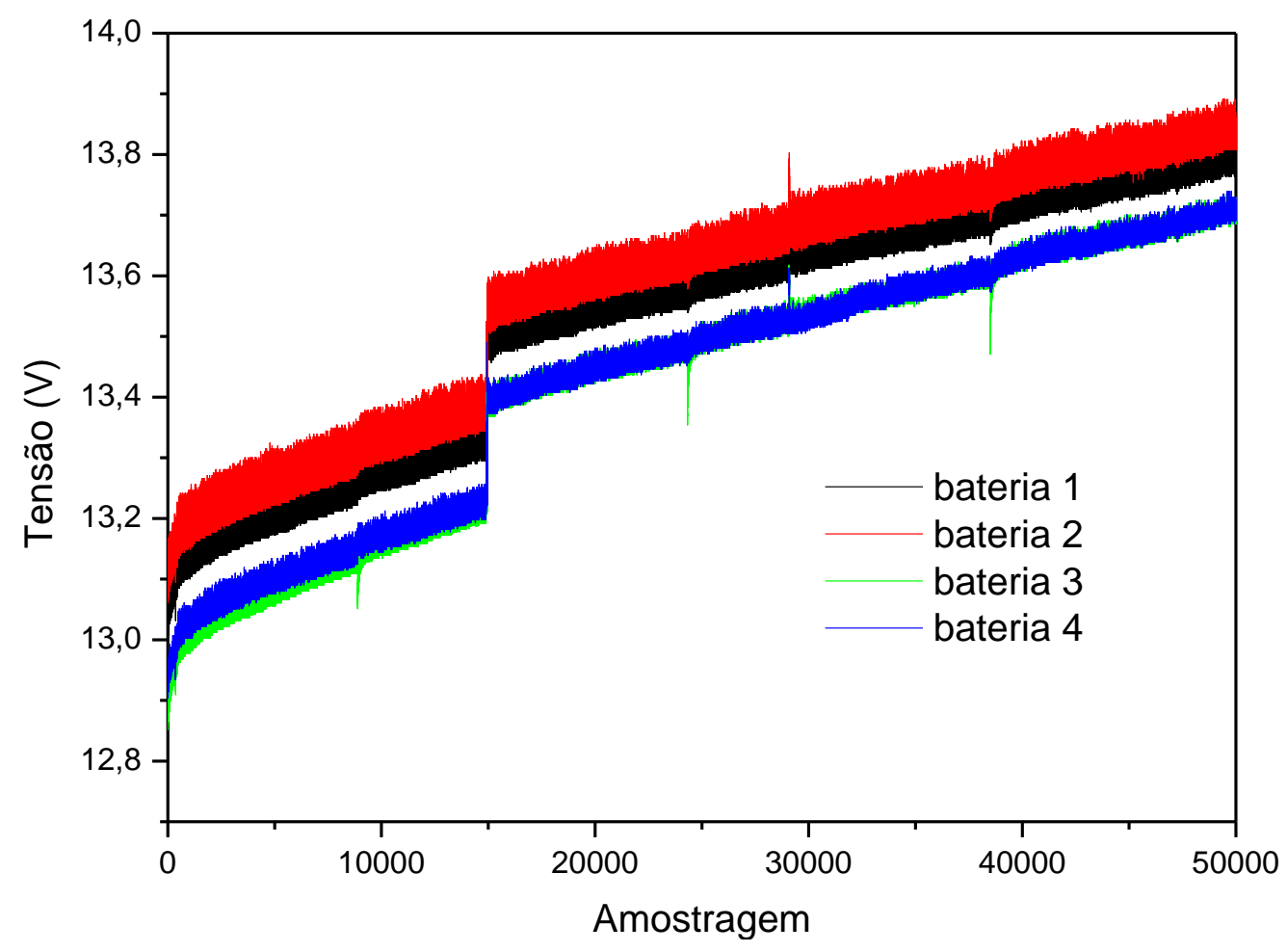

Gráfico 4.2 - Baterias em Carregamento

Fonte: Autor

O sistema se comportou de maneira constante, visto que as baterias usadas não apresentavam sinais de desgaste e mau uso. O sistema continuou o monitorando as baterias normalmente.

Conforme descrito no capítulo anterior, foi montado um sistema de testes, usando uma resistência conhecida na saída, possibilitando assim diagnosticar se a bateria possui capacidade de fornecer energia para o sistema quando necessário e, se não possui, isolar a mesma do sistema. $\mathrm{O}$ armazenamento da tensão durante o período em que as baterias estão conectadas às resistências de teste.

A primeira rotina de testes foi executada diariamente às 14:00h, considerando um período de teste em cada bateria de 10 minutos. Depois a periodicidade foi revista e alterada para 30 minutos por bateria, por 4 vezes ao dia. Ao final foi mantido um teste diário das baterias, mantendo-as conectadas no banco de resistências por 30 minutos. 


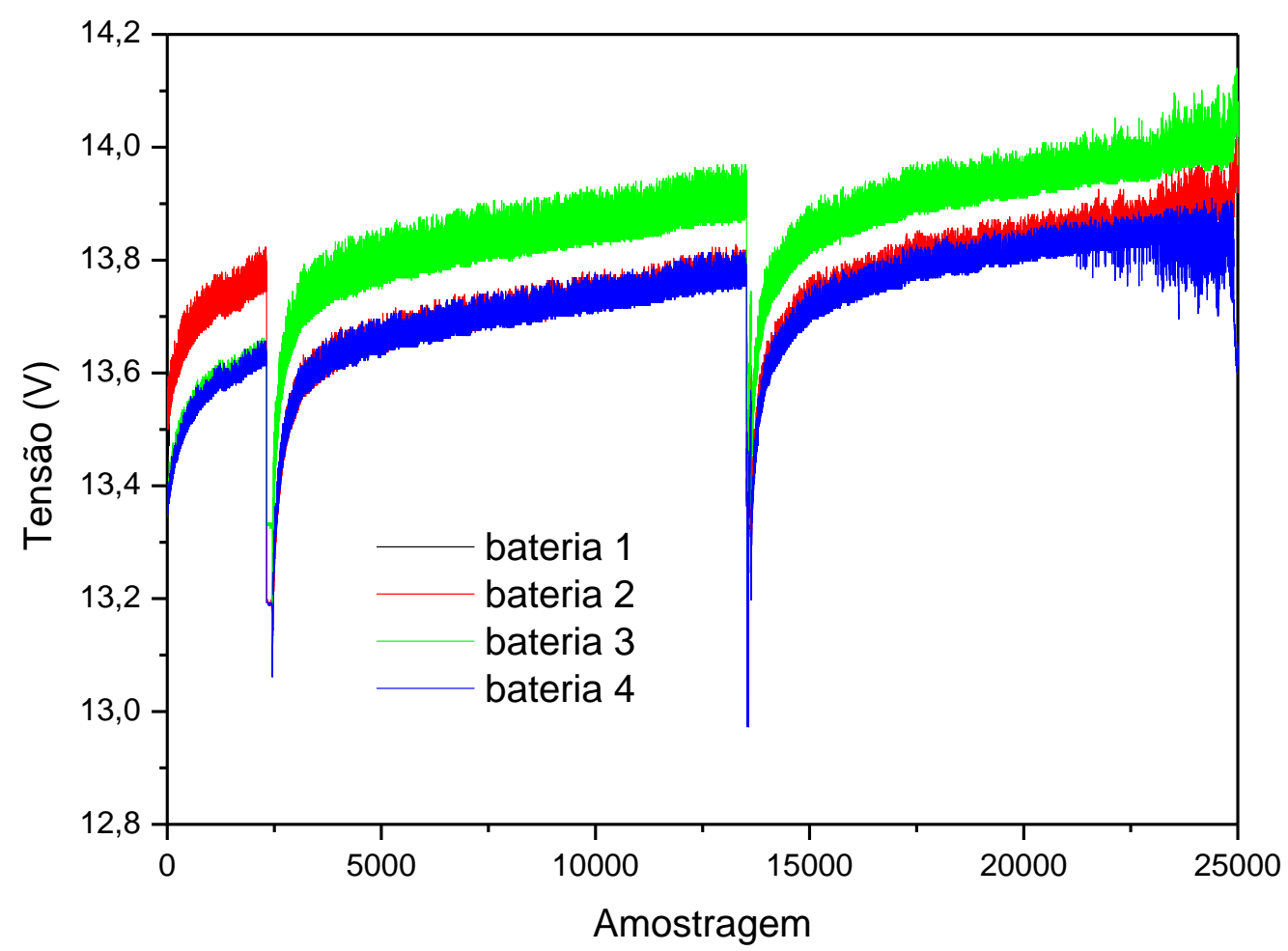

Gráfico 4.3 - Testes Diários de Resistência Interna ( 2 ciclos) Fonte: Autor

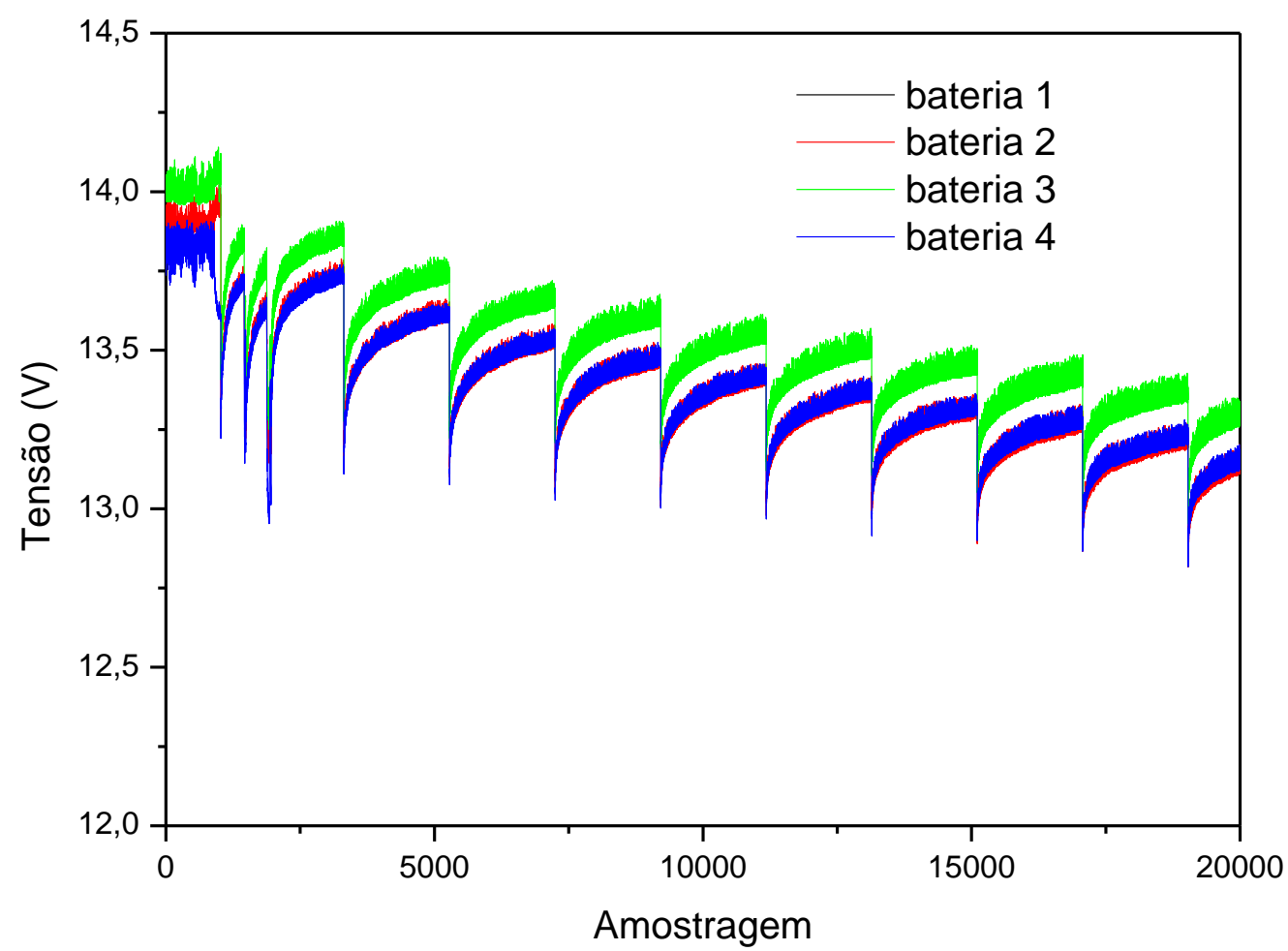

Gráfico 4.4 - Testes Diários de Resistência Interna (4 vezes ao dia) Fonte: Autor 
Por conta de um mal contato no terminal de leitura de tensão da Bateria-2, o sistema entendeu que a bateria estava apresentando baixa tensão, avisando o usuário sobre a unidade defeituosa e isolando-a do sistema. A fim de comprovar se havia alguma outra bateria sendo lida errada, foram isoladas as baterias e deixada apenas uma bateria no barramento por vez.

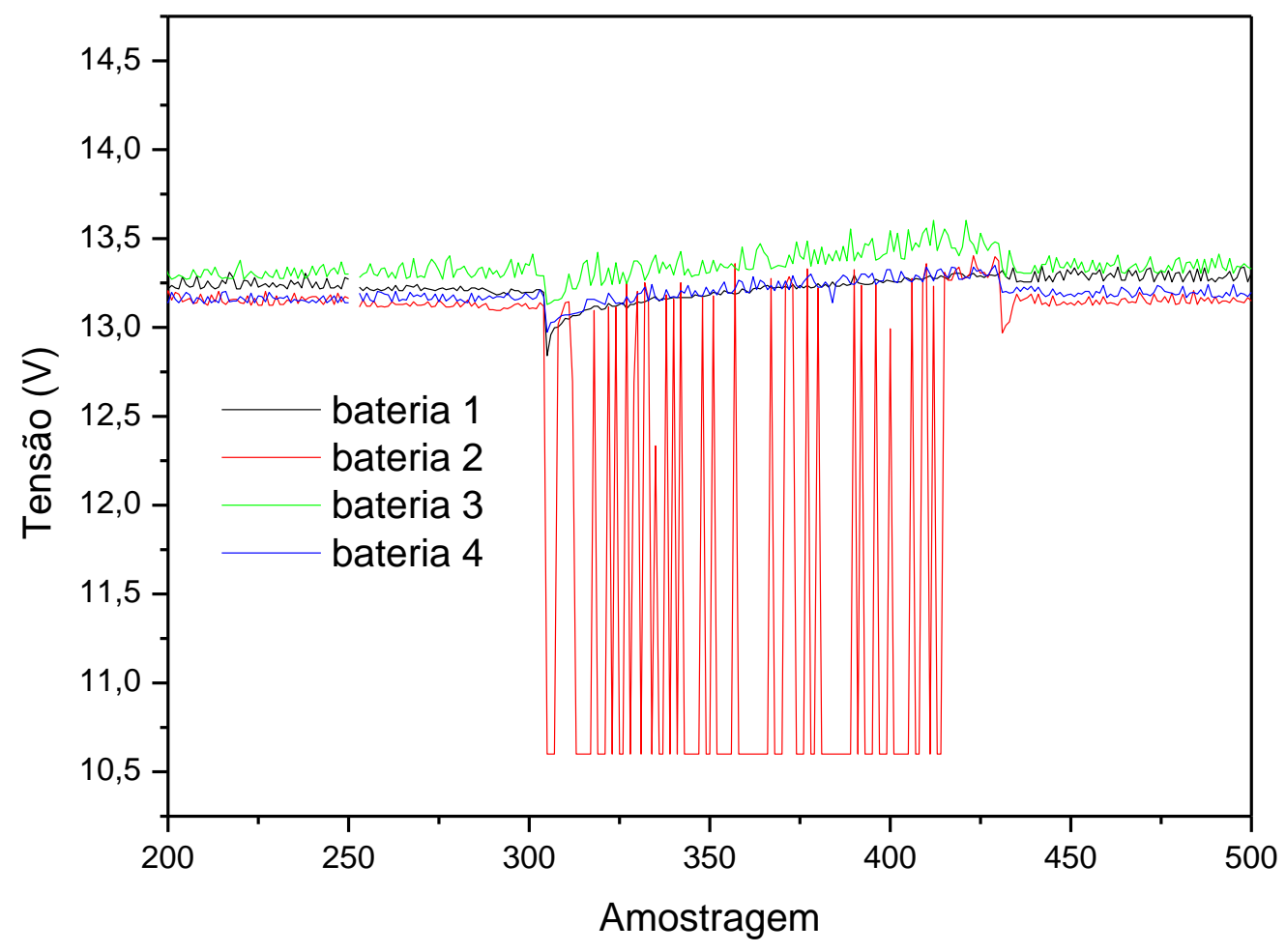

Gráfico 4.5 - Terminal de leitura de Tensão da Bateria-2 mal conectado Fonte: Autor 


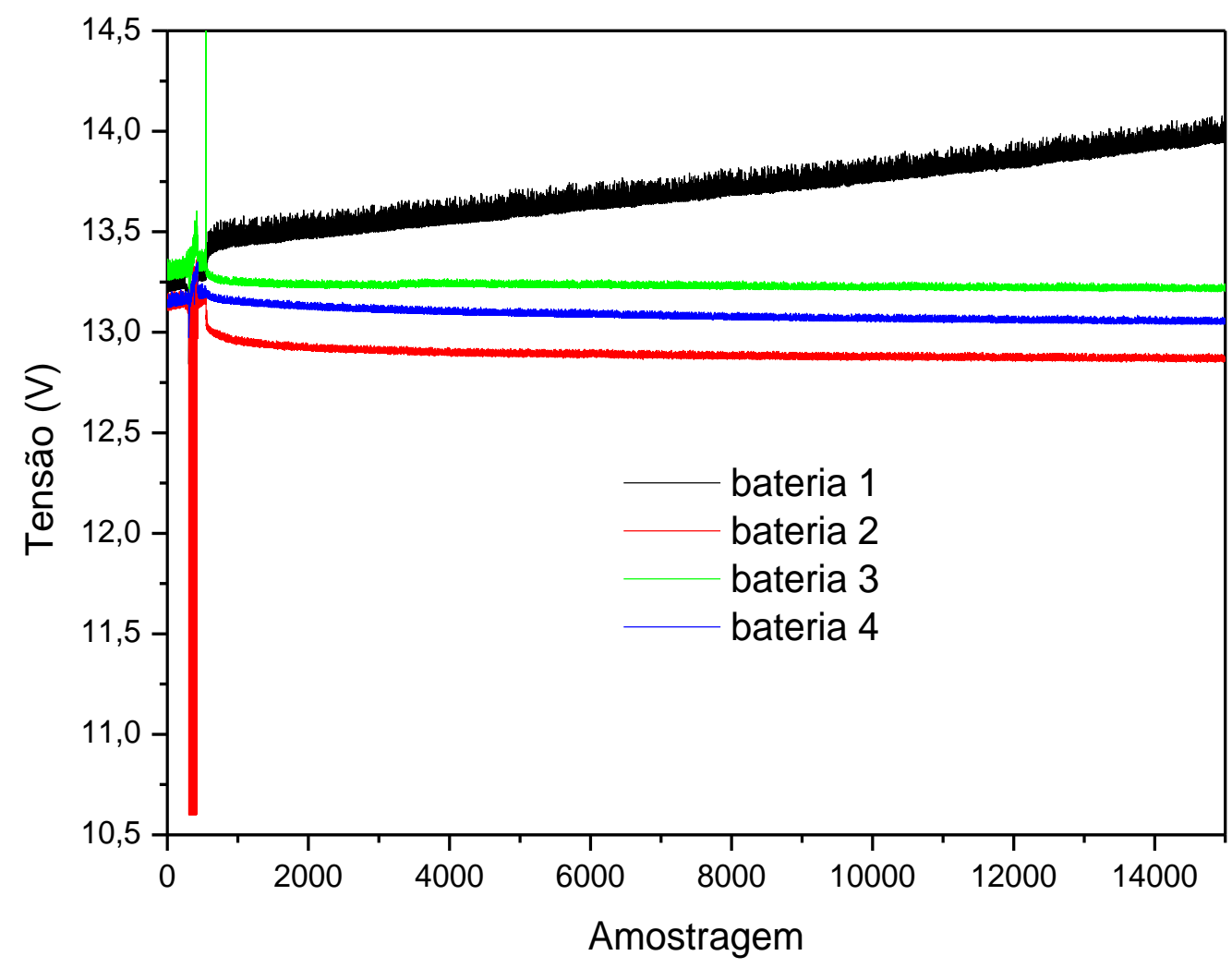

Gráfico 4.6 - Somente a Bateria-1 conectada no Barramento Fonte: Autor

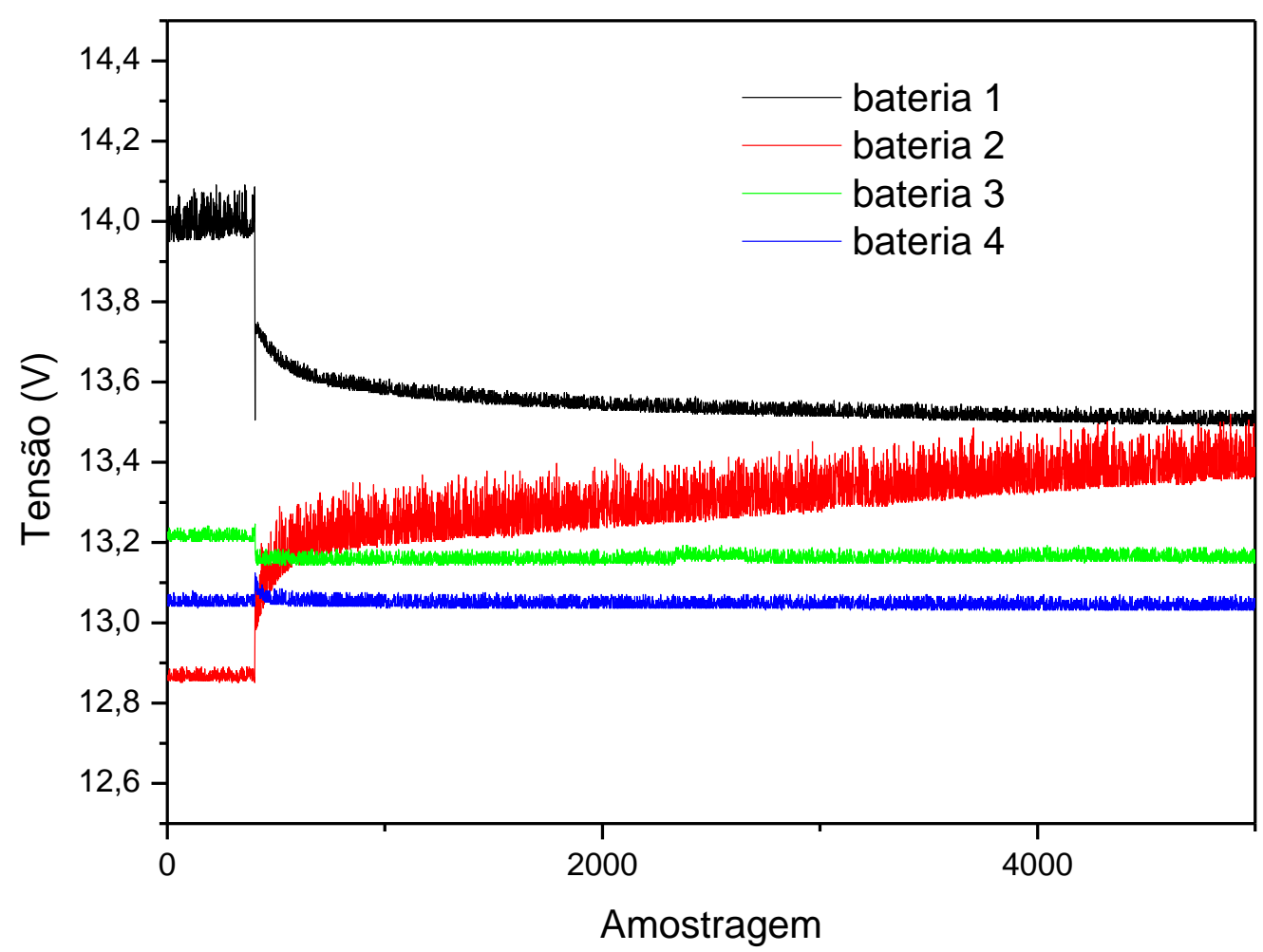

Gráfico 4.7 - Somente a Bateria-2 conectada no Barramento Fonte: Autor 
A Bateria-3 foi a primeira a apresentar falhas. Pelas leituras apresentadas pôdese diagnosticar que uma de suas células apresenta degradação do eletrodo de chumbo, fazendo com que os fragmentos se acumulem no fundo da bateria, ocasionando um curto-circuito entre as placas e diminuindo o valor de tensão final da bateria.

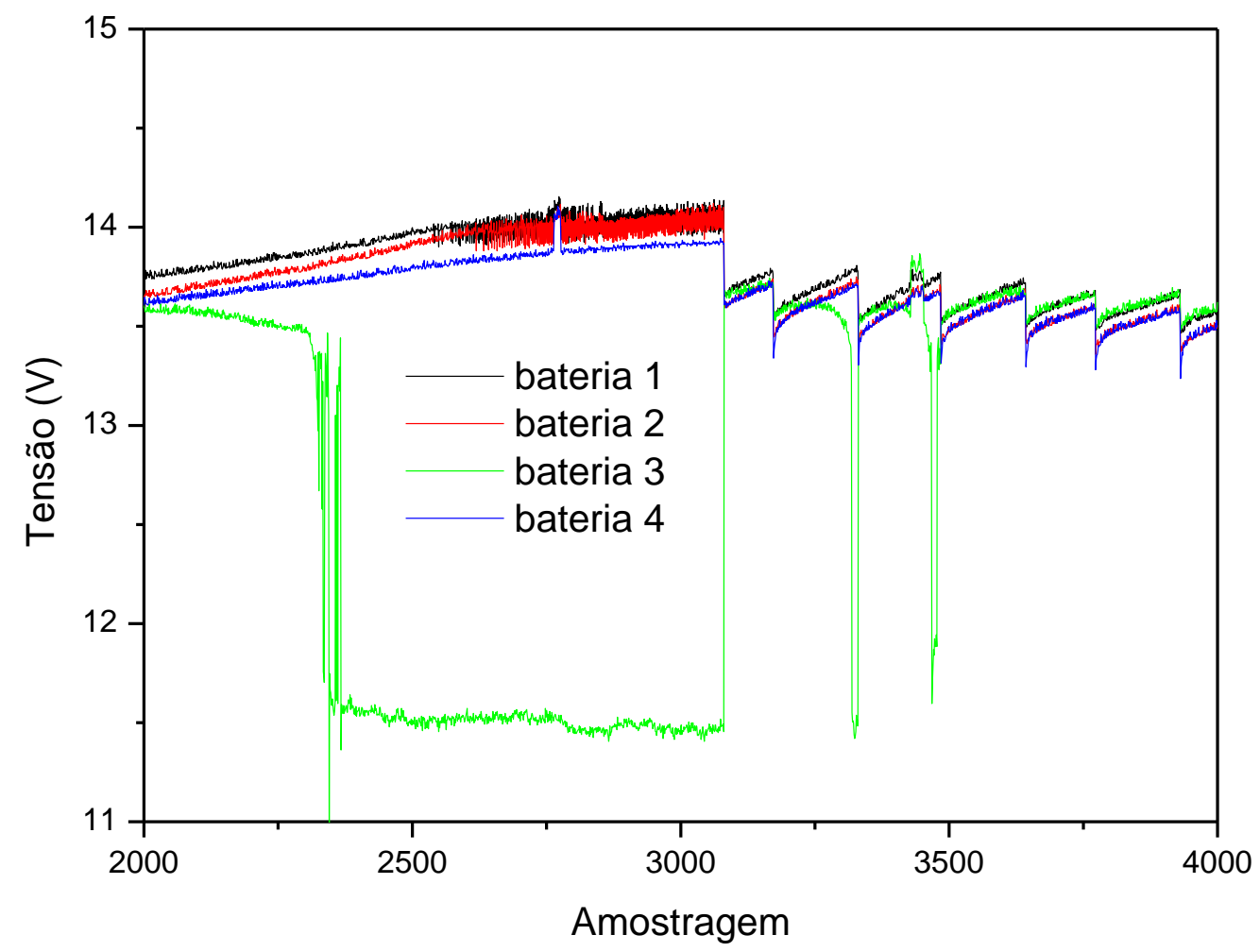

Gráfico 4.8 - Bateria-3 apresentando falhas Fonte: Autor

Por conta dessa falha apresentada na Bateria-3, o sistema foi reiniciado e os testes suspensos, a fim de manter a bateria carregada e descartar alguma possível falha de leitura. Depois de alguns dias os testes com o banco de resistências foram retomados e a Bateria-3 apresentou novamente baixas leituras de tensão. 


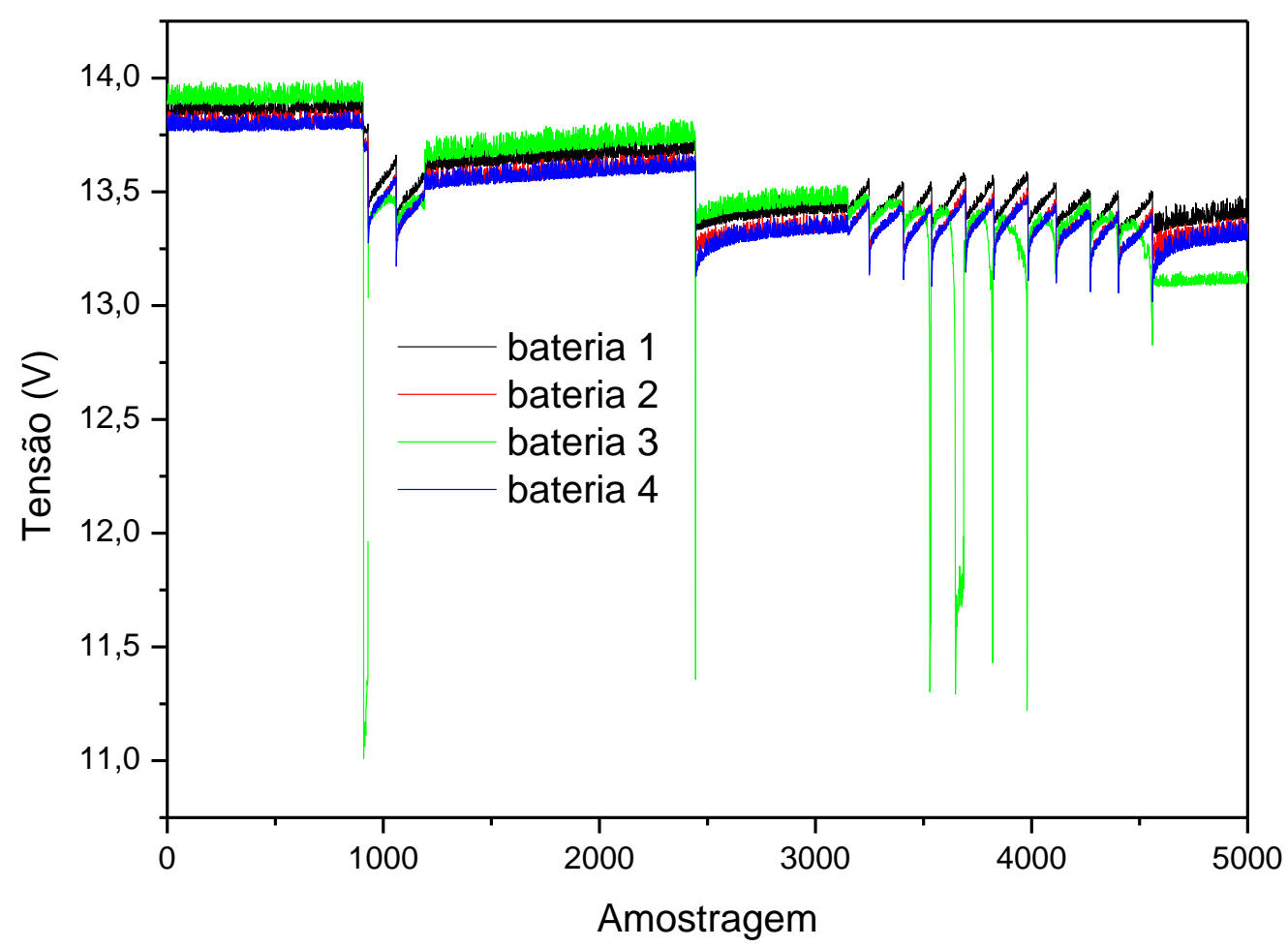

Gráfico 4.9 - Retomada do teste de Resistência Interna Fonte: Autor

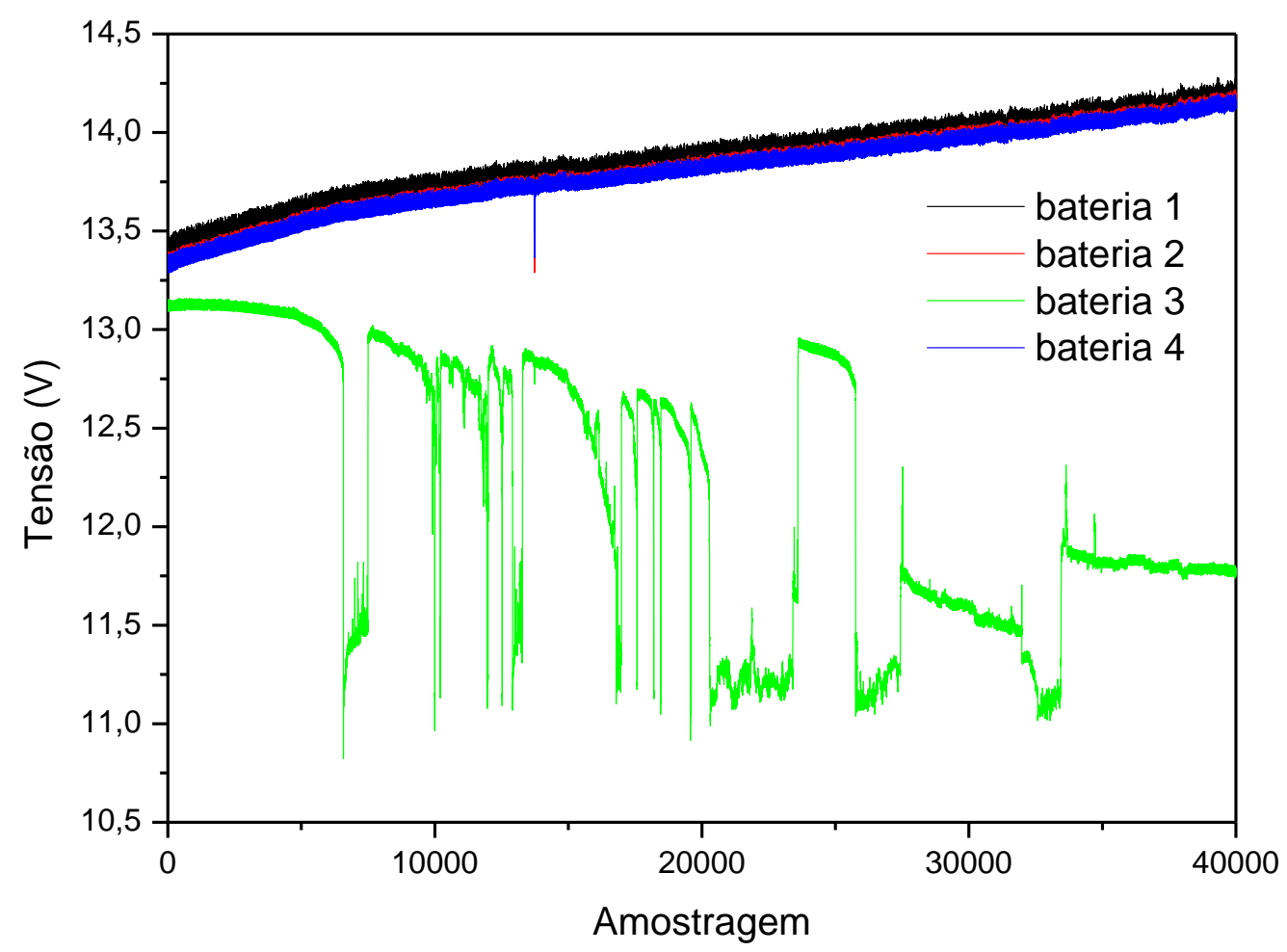

Gráfico 4.10 - Bateria-3 defeituosa, com tensão intermitente Fonte: Autor 
Já nesse gráfico a seguir é mostrada a variação da resistência interna das baterias. A bateria-3 também apresentou uma alta oscilação no valor calculado, com alguns valores chegando a aproximadamente $1311 \mathrm{~m} \Omega$.

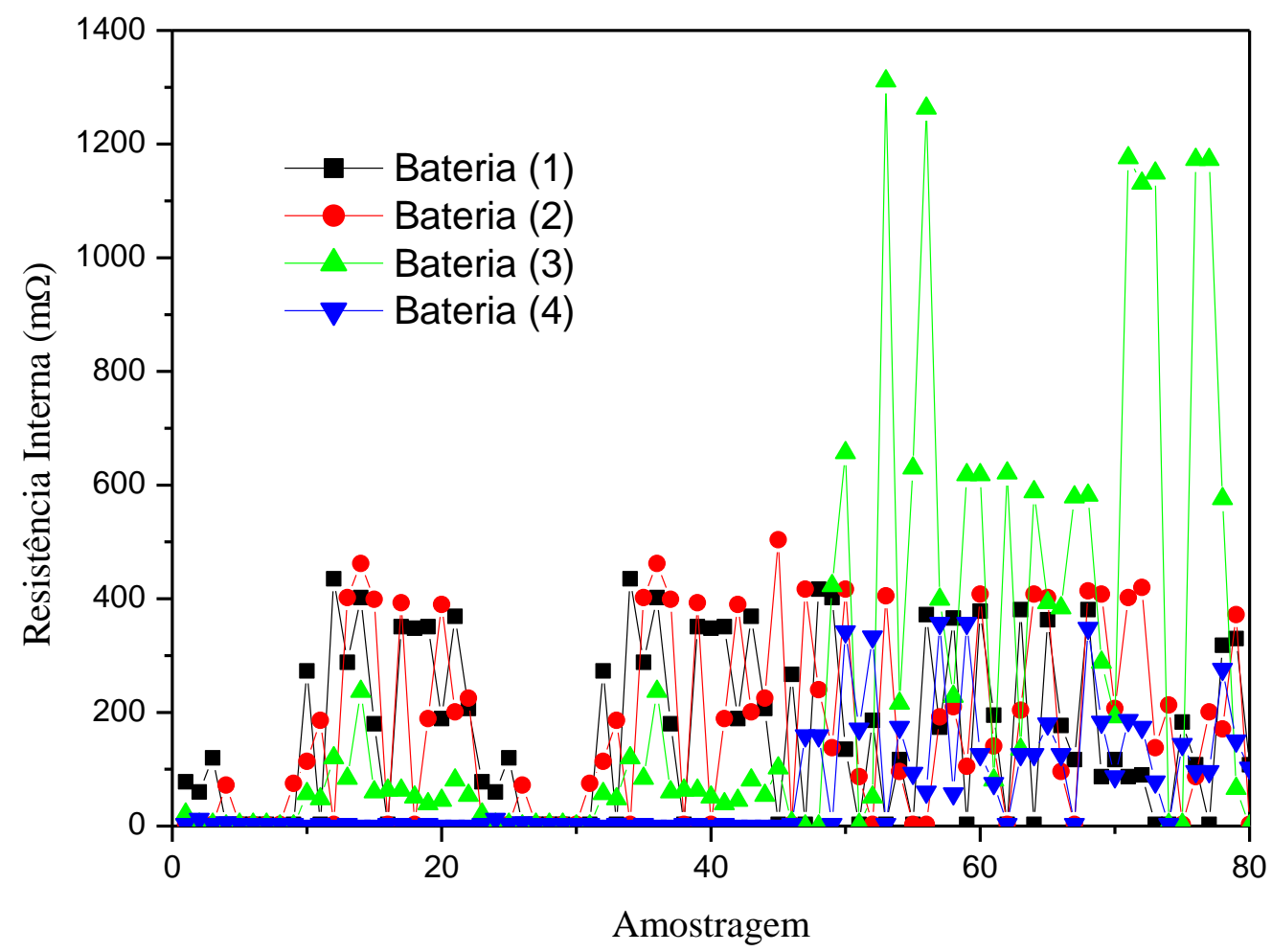

Gráfico 4.11 - Resistência Interna das Baterias

Fonte: Autor

O sistema está trabalhando atualmente na Ilha dos Arvoredos - Guarujá - SP e, visualizado tanto fisicamente quanto com a análise dos dados. Periodicamente os dados armazenados no cartão SD são recuperados, para uma posterior análise. 


\section{5 - CONCLUSÕES E PLANOS FUTUROS}

O uso da luz solar como energia para o sistema é uma fonte de energia variável que pode ter sua eficiência comprometida por conta de diversos fatores como: ambiente em que se encontra instalada, estando em exposição à agentes que podem criar uma opacidade na superfície da célula; quantidade de raios solares que incidem dependendo da meteorologia do local, podendo haver nuvens ou dias chuvosos por exemplo. Um desses prejuízos já esperados se deve por conta das células estarem expostas ao tempo, podendo acumular poeira. Limpar periodicamente a superfície das células é um procedimento que deve ser considerado, a fim de manter a eficiência dentro dos níveis desejados.

Um segundo fator que compromete a eficiência é a de se ter o uso misto de baterias novas e usadas. Especialmente considerando que as baterias estão ligadas em paralelo, a chance de que uma unidade apenas possa desbalancear todo o sistema é mais provável do que utilizando somente baterias novas. Isso se deve a alguns problemas já detalhados anteriormente como: oxidação das placas de chumbo, formando estruturas cristalinas e estáveis, impedindo a recombinação de elétrons e consequentemente diminuindo a área do eletrodo; aplicação de um nível de tensão superior ao de evaporação, gerando assim aquecimento e perda do eletrólito da bateria e, consequentemente, perda de capacidade e condutividade elétrica, a deterioração física dos eletrodos, colocando assim algumas células em curto-circuito. É fundamental que se tenha um controle da saída do regulador de tensão para o sistema composto de células solares e baterias chumbo-ácido. Deve-se evitar que o nível de tensão aplicado sobre as baterias seja superior ao nível de evaporação. Conforme diagnosticado com a Bateria-3 do circuito de teste, essa mesma matéria acabou sofrendo a deterioração de seus 
eletrodos, colocando em curto-circuito uma das células, ocasionado provavelmente pela precipitação do chumbo, alojamento e acumulação no fundo da mesma.

O uso seletivo dos bancos de baterias em função da carga aplicada durante o momento em que não se tem a geração de energia por parte das células se demonstra interessante neste caso, mantendo assim algumas baterias sempre em estado de espera. Essas baterias em espera no caso necessitam que seu carregamento seja apenas mantido com um nível mínimo a fim de se evitar a oxidação dos eletrodos, e assim aumentando assim a vida útil das mesmas. Para tanto se faz interessante o uso de múltiplos sistemas de geração de energia, para ao menos manter esse nível de tensão mínimo. 


\section{REFERÊNCIAS BIBLIOGRÁFICAS}

ALMINAUSKAS, Vaidevutis; "Performance Evaluation of Lead Acid Batteries for use with Solar Panels", Naval Surface Warfare Center, Crane, Indiana, United States of America, 1993.

AMATO, Edward; ASHTON, Curtis; BALASH, Gary; BYRNE, Allen; CANTOR, William; CHAPMAN, Terry; CHATWIN, Troy; DEMAR, Pete; HECTORS, Paul A. C.; KOPERA, John; LAMBERT, Daniel; MCCLUER, Stephen; MCMENAMIN, Daniel; POLENZ, John; SCHMIDT, Robert; TRESSLER, Richard; VARGA, Lesley; VECHY, Stephen; "IEEE Recommended Practice for Installation Design and Installation of Valve-Regulated Lead-Acid Batteries for Stationary Applications - IEEE Std 1187”. Stationary Batteries Committee of the IEEE Power and Energy Society, Institute of Electrical and Electronics Engineers, New York, New York, United States of America, 2013.

ASHTON, Curtis; BASSO, Thomas; CHAMBERLIN, Jay; HUND, Thomas; MCNUTT, Peter; NASRAT, Haissam; NISPEL, Michael; RALLO, Robert; SANDERS, Kenneth; VECHY, Stephen L.; WILES, John; "IEEE Guide for Selecting, Charging, Testing, and Evaluating Lead-Acid Batteries Used in Stand-Alone Photovoltaic (PV) Systems - IEEE Std 1361”. IEEE Standards Coordinating Committee 21, Institute of Electrical and Electronics Engineers, Inc., New York, New York, United States of America, 2014. 
ALLEGRO MICROSYSTEMS INC. "Datasheet ACS712”, Disponível em: www.allegromicro.com/ /media/Files/Datasheets/ACS712-Datasheet.ashx. Acesso em Agosto de 2014.

ARDUINO. Disponível em: http://www.Arduino.cc/ Acesso em: Julho de 2014

ATMEL CORPORATION INC. "Datasheet ATmega2560”, Disponível em: http://www.atmel.com/images/doc2549.pdf. Acesso em Junho de 2015.

AUGARTEN, STAN; "State of the Art: A Photographic History of the Integrated Circuit”, Editora Ticknor \& Fields, 1983

BO, $\mathrm{Hu}$; YANBO, Che; WEN, Teng; LEIJIAO, Ge; "Implementation of Battery Charging and Discharging System in Photovoltaic System". Key Laboratory of Smart Grid of Ministry of Education, Tianjin University, Tianjin, China, 2013.

DECKER, Franco; "Volta and the "Pile"". Electrochemistry Encyclopedia. Case Western Reserve University. Disponível em http://electrochem.cwru.edu/encycl/artv01-volta.htm Acesso em Novembro de 2014.

EMERSON NETWORK POWER, "Liebert Monitoring Solutions: Protecting Your Investment Against The Unknown”. Disponível em http://www.emersonnetworkpower.com/documentation/enus/products/surgeprotection/documents/uptime-monitoring_32000-r02-09.pdf. Acessado em Setembro de 2014. 
ENERGIZER INC.; “Carbon Zinc Batteries Product Safety Datasheet”. Disponível em http://data.energizer.com/PDFs/carbonzinc_psds.pdf Acessado em Janeiro de 2015

FUNDAÇÃO FERNANDO LEE; Disponível em: http://www.fundacaofernandolee.org/ Acesso em Janeiro de 2015

INSTITUTO NEWTON C. BRAGA; "Como funcionam os sensores de Efeito Hall”, Disponível em http://www.newtoncbraga.com.br/index.php/como-funciona/6640-comofuncionam-os-sensores-de-efeito-hall-art1050 Acesso em Janeiro de 2015

KOUTROULIS, E.; KALAITZAKIS, K.; "Novel battery charging regulation system for photovoltaic applications”. Electric Power Applications, IEE Proceedings, 2004.

KURISAWA, Isamu; IWATA, Masashi; “Internal Resistance and Deterioration of VRLA Battery - Analysis of Internal Resistance obtained by Direct Current Measurement and its application to VRLA Battery Monitoring Technique". Japan Storage Battery Co. Ltd., Nishiosho, Kissshoin, Minami-ku, Kyoto, Japan. 1997.

KUTLUAY, Koray; ÇADIRCI, Yigit; ÖZKAZANÇ, Yakup S.; ÇADIRCI, Isik; “A New Online State-of-Charge Estimation and Monitoring System for Sealed Lead-Acid Batteries

in Telecommunication Power Supplies". Electrical and Electronics Engineering Department, Middle East Technical University, Ankara, Turkey, 2005. 
LAN, Chengrong; SU, Juan; "The Design of On-line Monitoring System of VRLA Battery”. Department of Electrical and Information Engineering, Hunan University, Changsha, China, 2013.

LANGELLA, Roberto; TESTA, Alfredo; VENTRE, Chiara; “A New Model of LeadAcid Batteries Lifetime in Smart Grid Scenario", Department of Industrial and Information Engineering, Second University of Naples, Aversa, Italy, 2014.

LIH, Wen-Chen; YEN, Jieh-Hwang; SHIEH, Fa-Hwa; LIAO, Yu-Min; "Second Use of Retired Lithium-ion Battery Packs from Electric Vehicles: Technological Challenges, Cost Analysis and Optimal Business Model”. The Second Research Division, ChungShan Institute of Science \& Technology, Taoyuan County, Taiwan, Republic of China, 2012.

LINDEN, David; REDDY, Thomas B.; “Linden's Handbook of Batteries, Fourth Edition”. Editora McGraw Hill. 2011.

MCROBERTS, Michael; “Arduino básico / Michael McRoberts ; (tradução Rafael Zanolli)”. São Paulo, Novatec Editora, 2011.

MICROCHIP. “Documentação PIC18F4550”. Disponível em: http://ww1.microchip.com/ downloads/en/DeviceDoc/39632e.pdf. Acesso em Junho de 2010 
MIYADAIRA, Alberto Noboru, “Microcontroladores PIC18 - Aprenda e Programe em Linguagem C”. Editora Érica Ltda. 2010

NATIONAL AERONAUTICS AND SPACE ADMINISTRATION (NASA); "Estação Espacial Internacional”. Disponível em http://spaceflight.nasa.gov/gallery/ Acessado em Janeiro de 2015.

NÚCLEO DE PESQUISA DE CIÊNCIAS; “A bateria do seu carro só funciona graças à relatividade", Disponível em https://nupesc.wordpress.com/2012/10/29/a-bateria-doseu-carro-so-funciona-gracas-a-relatividade/ Acesso em Fevereiro de 2014.

PIMENTEL, D.; MUSILEK, P.; KNIGHT, A.; "Energy Harvesting Simulation for Automatic Arctic Monitoring Stations, Electrical and Computer Engineering", University of Alberta, Edmonton, Alberta, Canada, IEEE Electrical Power \& Energy Conference, 2010

PRAISUWANNA, Nattapat; KHOMFOI, Surin; “A Seal Lead-Acid Battery Charger for Prolonging Battery Lifetime Using Superimposed Pulse Frequency Technique”, King Mongkut's Institute of Technology, Bangkok, Thailand, 2013.

RAMSDEN, Edward; "Hall-effect sensors: theory and applications $-2^{\text {nd }}$ edition", Editora Elsevier, 2006.

STRICKLAND, Dani; CHITTOCK, Laurence; STONE, David A.; FOSTER, Martin P.; PRICE, Brian; "Estimation of Transportation Battery Second Life for Use in Electricity 
Grid Systems". Department of Engineering and Applied Science, Aston University, Birmingham, United Kingdom, 2014.

UNIVERSIDADE DE CAMBRIDGE; "DoITPoMS - Dissemination of Information Technology for the Promotion of Materials Science”. Disponível em http://www.doitpoms.ac.uk/ Acessado em Janeiro de 2015. 


\section{APÊNDICE A - OUTROS TIPOS DE BATERIAS}

- Íons de Lítio (Li-ion): Nos dispositivos portáteis como celulares, smart phones, laptops são usadas baterias de Íons de Lítio, capazes de produzir 3,6V por célula e possuem tecnologia "seca", ao contrário da bateria Chumbo-Ácida;

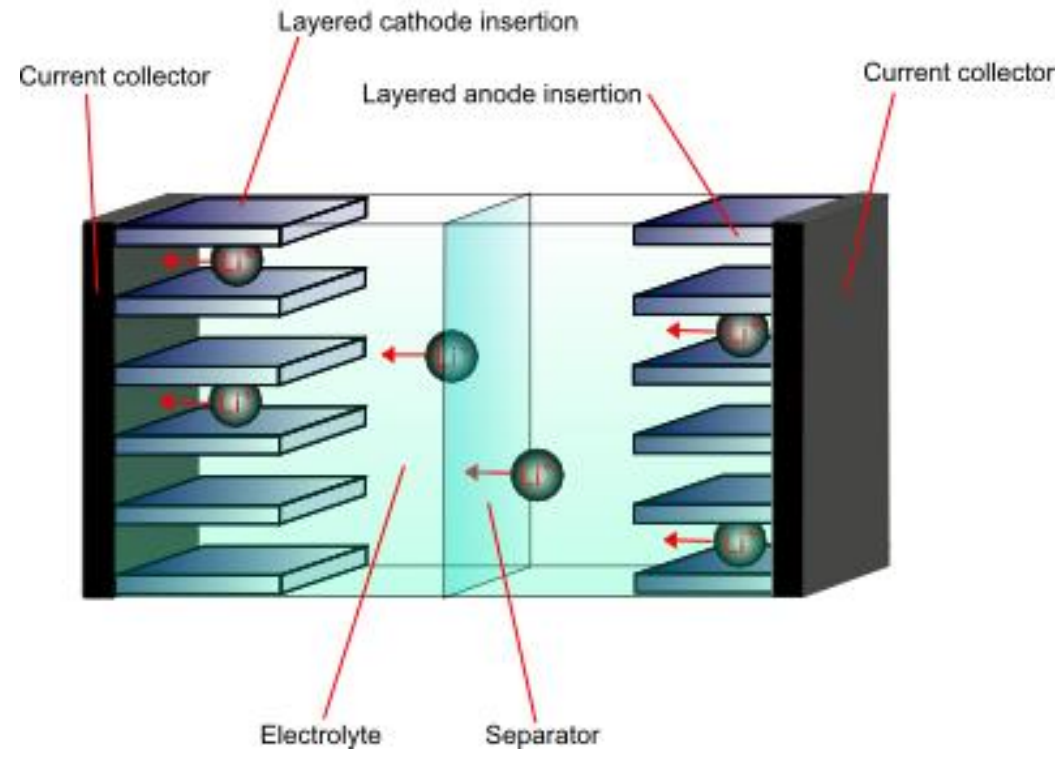

Figura A.1 - Bateria de Íons de Lítio durante a descarga Fonte: DoITPoMS - Universidade de Cambridge - UK

- Níquel-Cádmio (Ni-Cd): Muito usada no início nos tamanhos "AA" e "AAA" para substituir algumas pilhas alcalinas, em máquinas fotográficas, rádios de comunicação, aparelhos eletrônicos etc., mas sendo pouco a pouco substituída pela NiMH. A bateria de Níquel-Cádmio produz $1,2 \mathrm{~V}$ por célula e também trabalha com tecnologia "seca";

- Níquel-hidreto Metálico (Ni-MH): Também encontrada nos tamanhos “AA” e "AAA", a bateria de Ni-MH vem para substituir a bateria de Ni-Cd, por conta de sua superior capacidade de fornecimento de energia e menor "efeito-memória". A bateria Níquel-hidreto Metálico também produz $1,2 \mathrm{~V}$ por célula e trabalha com tecnologia "seca". 


\section{APÊNDICE B - OUTRAS FORMAS DE CARREGAMENTO}

- Carregamento por Corrente Constante: Essa forma de carregamento, tendo somente um nível de corrente ou vários dependendo do tamanho do sistema, não tão comumente usado para baterias chumbo-ácidas. Isso se deve por conta da necessidade de ajustes do nível de corrente, a não ser que um baixo nível de corrente seja mantido na saída do carregador, o que resultaria em longos tempos de recarga de 12 horas ou mais. Esse tipo de recarga normalmente é usado para sistemas com baterias pequenas.
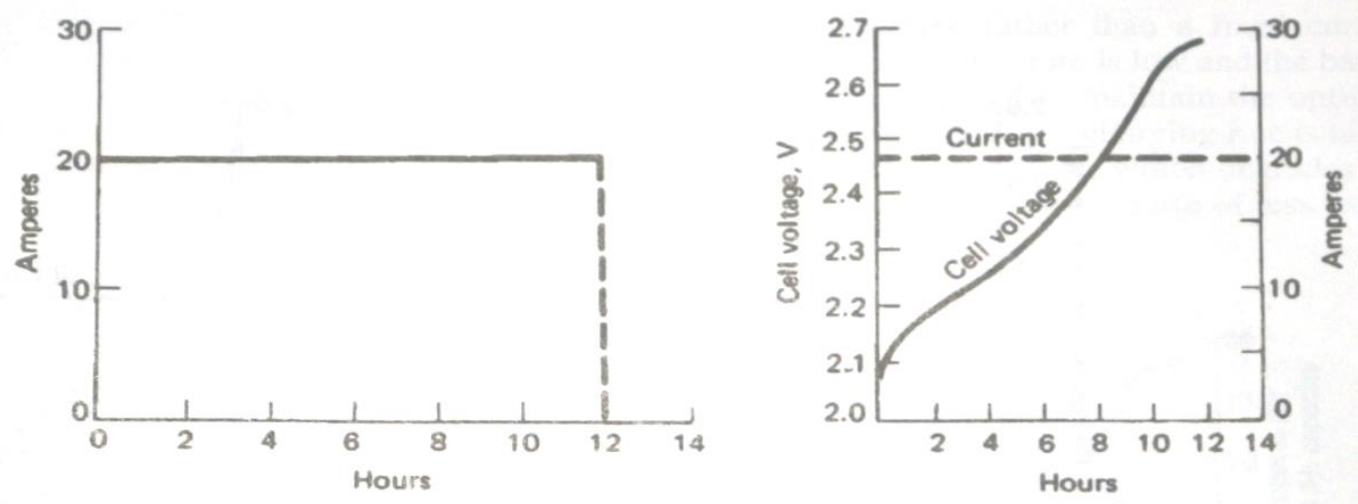

(a)
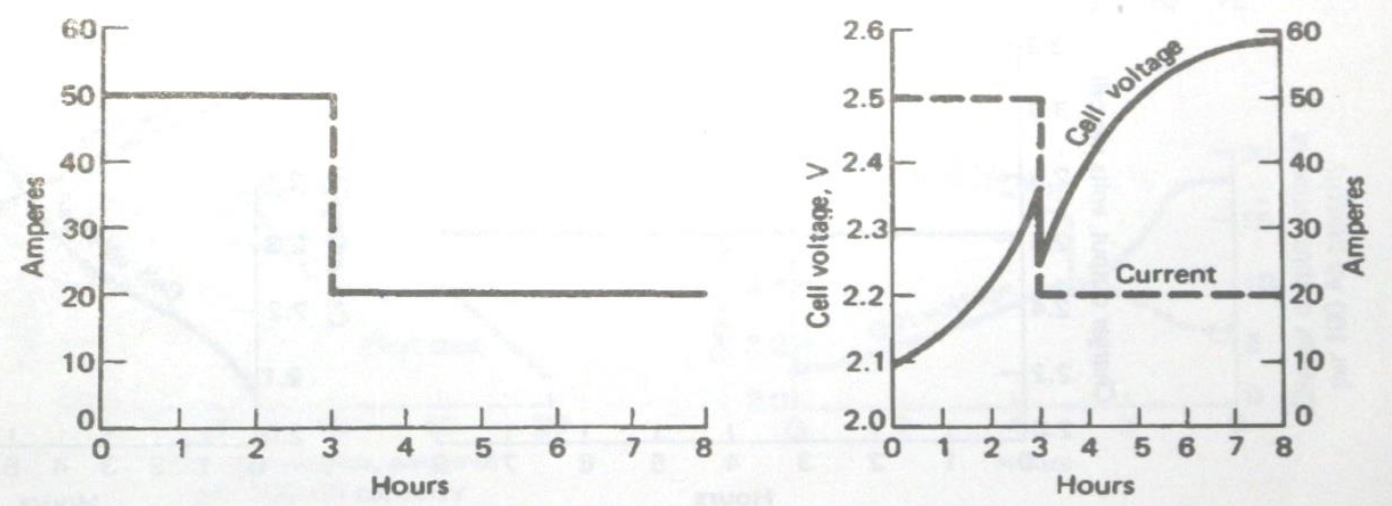

Gráfico B.1 - Curvas características do Carregamento por Corrente Constante Fonte: Linden's Handbook of Batteries

Esse tipo de carregamento também é comum ser encontrado em laboratórios. Por conta de não ser necessário o uso constantemente, é possível simplesmente 
encontrar a corrente de recarga recomendada da bateria, ajustar a corrente de saída no carregador e pronto.

Uma variação desse método de carregamento é utilizado para manter as baterias sempre $100 \%$ carregadas, aplicando-se uma corrente baixa e constante, recarregando-as por perdas causadas por correntes de fuga e também para repor a energia usada durante o uso intermitente das baterias. Esse método é comumente usado em sistemas veiculares e outros tipos semelhantes, em que a bateria é removida do veículo ou de seu carregador (LINDEN; REDDY, 2011, cap. 16).

\section{- Carregamento por Corrente Decrescente: Carregamento por corrente} decrescente é uma variação do carregamento por tensão constante, utilizando circuitos eletrônicos mais simples, com o objetivo de reduzir custos. As características dessa maneira de carregamento estão mostradas nos gráficos abaixo. Os valores iniciais de carregamento são limitados, mas a tensão e corrente aplicadas são ligeiramente acima de $2,39 \mathrm{~V}$ por célula a $25^{\circ} \mathrm{C}$ antes da bateria retornar ao estado de completamente carregada. Esse método resulta em perda por evaporação no ponto crítico do carregamento, e a temperatura na célula da bateria aumenta. 


\begin{tabular}{|c|c|c|}
\hline $\begin{array}{c}\text { Temp. } \\
\text { Eletrólito, }{ }^{\circ} \mathrm{C}\end{array}$ & $\begin{array}{c}\text { Tensão Limite da } \\
\text { Célula, } \mathbf{V}\end{array}$ & $\begin{array}{c}\text { Fator de } \\
\text { Correção, } \mathbf{V}\end{array}$ \\
\hline 50 & 2,300 & $-0,090$ \\
\hline 40 & 2,330 & $-0,060$ \\
\hline 30 & 2,365 & $-0,025$ \\
\hline 25 & 2,390 & 0 \\
\hline 20 & 2,415 & 0,025 \\
\hline 10 & 2,470 & 0,080 \\
\hline 0 & 2,540 & 0,150 \\
\hline-10 & 2,650 & 0,260 \\
\hline-20 & 2,970 & 0,508 \\
\hline
\end{tabular}

Tabela B.2- Fator de correção da tensão, em função da temperatura do Eletrólito Fonte: Linden's Handbook of Batteries

A taxa de evaporação e aumento de temperatura são variáveis que dependem de como o carregador é projetado, e a vida útil da bateria pode ser diminuída por conta de uma temperatura excessiva da bateria e perda por sobrecarga. A tensão de evaporação diminui na medida em que se tem o aumento de temperatura. 
A finalização do carregamento é algumas vezes controlado por uma tensão fixa ao invés de uma corrente fixa. Dessa forma quando uma nova bateria tem uma
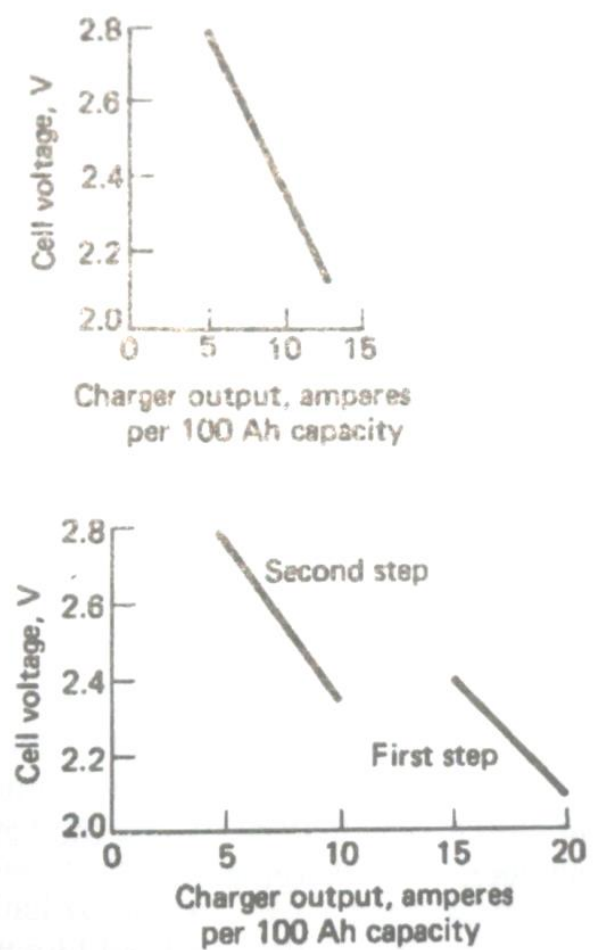

\section{Gráfico B.3 - Curva Característica do Carregamento por Corrente Decrescente Fonte: Linden's Handbook of Batteries}

força contra eletromotriz elevada, a taxa de carregamento final é baixa e a bateria pode não receber carga suficiente no período disponibilizado para manter um nível de carregamento ótimo. Já quando a bateria tem algum tempo de uso, a força contra eletromotriz é baixa, e a taxa de carregamento é mais elevada do que a normalmente usada na finalização, assim a bateria recebe uma carga excessiva, no qual diminui novamente a vida útil.

Conclui-se que o carregamento por corrente decrescente reduz a vida útil da bateria, no entanto pode justificar o uso de um equipamento mais barato. Dependendo da aplicação, é mais viável trocar as baterias usadas por novas ao invés de se investir em uma forma de carregamento em que se prolongue a vida útil da bateria. 
Em sistemas fotovoltaicos ou outros sistemas projetados para uma vida longa, sistemas de carregamento e circuitos de regulagem deverão produzir um perfil de tensão e corrente equivalentes aos usados nas indústrias. O método de carregamento por tensão constante com uma corrente inicial de carregamento constante produzem melhores resultados. Melhor controle para maximizar a vida útil da bateria bem como sua energia de saída é atingido quando uma longa descarga e um tempo de recarga são prédeterminados e possuem um ciclo repetitivo, condições nem sempre encontradas em sistemas fotovoltaicos, pelo simples fato de agentes externos influenciarem diretamente nesse ponto (nebulosidade, sujeira, etc.).

- Carregamento Pulsado: O carregamento pulsado é também usado para sistemas de tração, particularmente na Europa. Neste caso o carregador é desconectado dos terminais das baterias periodicamente, e a tensão de circuito-aberto da bateria é automaticamente medida. Se a tensão de circuito-aberto for superior ao valor prédeterminado, dependendo da temperatura de referência, o carregador não supre energia para a bateria. No entanto se a tensão de circuito-aberto da bateria for diminuindo com o tempo até o valor de referência, o carregador fornece um pulso de corrente contínua por um determinado período. Normalmente o tempo de descarga e a duração do pulso são os mesmos.

A perda de capacidade em reter carga de uma bateria influencia diretamente nessa forma de carregamento, simplesmente por conta do nível de tensão em circuitoaberto se tornar menor ou bem próximo do valor pré-determinado ou ainda cair repentinamente, a bateria acaba precisando ficar conectada quase $100 \%$ do tempo ao carregador. 
- Carregamento Rápido: Em diversas aplicações, é desejável ter as baterias carregadas em apenas uma hora ou menos. Para este caso o controle do carregamento é relevante, de tal forma a manter a morfologia dos eletrodos das baterias, para prevenir um aumento na temperatura, especialmente nos pontos mais suscetíveis a corrosão, conversão em óxido não-condutor, materiais de alta solubilidade e decomposição, também a fim de evitar sobrecarga e vaporização. Por essas condições estarem mais propensas a acontecer durante uma elevada taxa de recarga, o controle apurado do carregamento é crítico.

O controle das variáveis Tensão e Corrente durante o carregamento vem fazendo com que essa forma de carregamento se torne mais atrativa, com o desenvolvimento de micro-dispositivos como micro-controladores, sensores etc.. Esses dispositivos podem também ser usados para a finalização do carregamento, limitação da corrente de carga, ou ainda trocar entre modos de carregamento quando uma potencial condição de dano à bateria está prestes a acontecer durante um modo ativo.

Diversas técnicas de carregamento foram desenvolvidas para um carregamento rápido efetivo. Em um método, chamado de "reflexo", um breve pulso de frações de segundo é descarregado no sistema. Essa técnica foi considerada efetiva quanto à prevenção do aumento repentino de temperatura durante uma elevada taxa de carregamento. 


\section{APÊNDICE C - OUTRAS APLICAÇÕES DO SENSOR HALL}

A forma do sinal que é obtido da saída de um Sensor de Efeito Hall é determinado pelo posicionamento do sensor em relação ao campo magnético. Desse modo, existem diversas configurações relativas ao posicionamento do sensor em relação ao campo que podem ser utilizadas pelo projetista e/ou engenheiro ao planejar o circuito detector e os dispositivos em que o sensor será instalado.

\section{Aproximação simples}

Neste método o sensor e o ímã que gera o campo magnético se aproximam perpendicularmente. Neste caso, quanto menores forem as distâncias, maior será a ação sobre o chip. Este arranjo pode ser aplicado em uma chave de fim de curso ou ainda para se medir a velocidade de aproximação ou afastamento de uma peça.

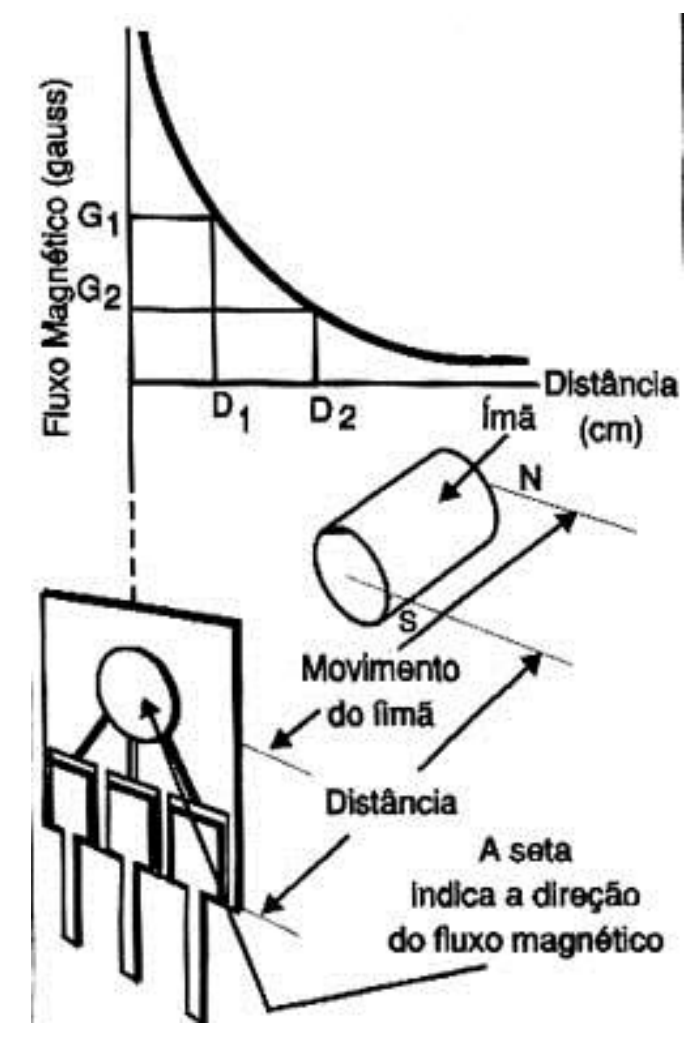

Figura C.1 - Sensor de Efeito Hall - Aproximação simples Fonte: Instituto Newton C. Braga 
Utilização de um Sensor de Efeito Hall com a configuração por aproximação simples e o gráfico que mostra a variação do campo magnético sobre o sensor.

\section{Passagem lateral unipolar}

Nesta configuração, um ímã simples passa diante do sensor de modo que as suas linhas de força possam atuar sobre o chip. Este tipo de arranjo é adequado em aplicações menos críticas, isto é, que exijam baixa sensibilidade, se comparada a configuração por aproximação simples.

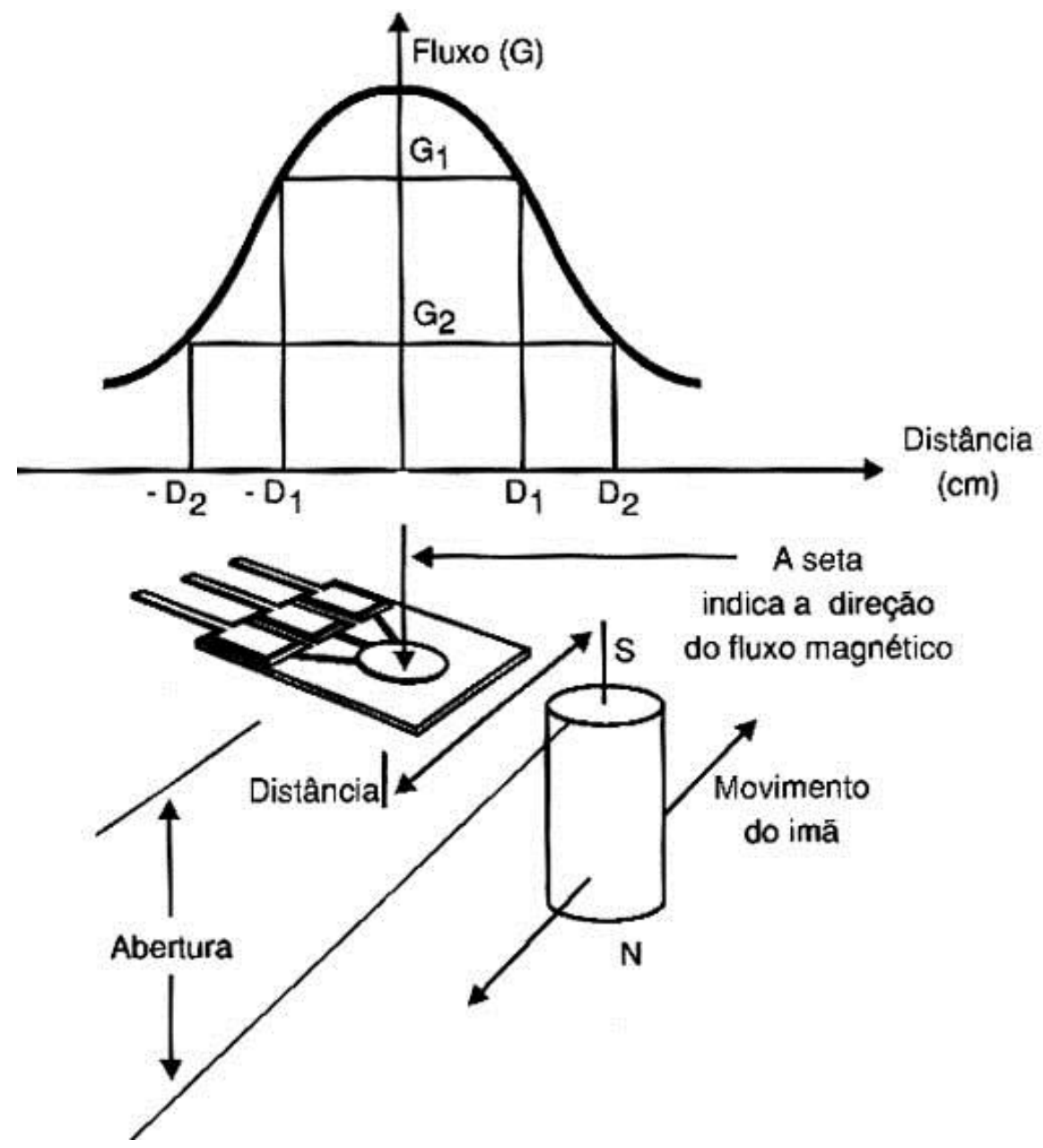

Figura C.2 - Sensor de Efeito Hall - Passagem Lateral Unipolar Fonte: Instituto Newton C. Braga 
Utilização de um Sensor de Efeito Hall com a configuração por passagem lateral unipolar e o gráfico que mostra a variação do campo magnético sobre o sensor.

\section{Passagem lateral bipolar}

Neste arranjo, dois imãs são colocados juntos (formando um ímã "bipolar") de modo que possam gerar um campo magnético duplo. Quando os dois imãs passarem lateralmente pelo sensor, o campo irá atuar sobre este.

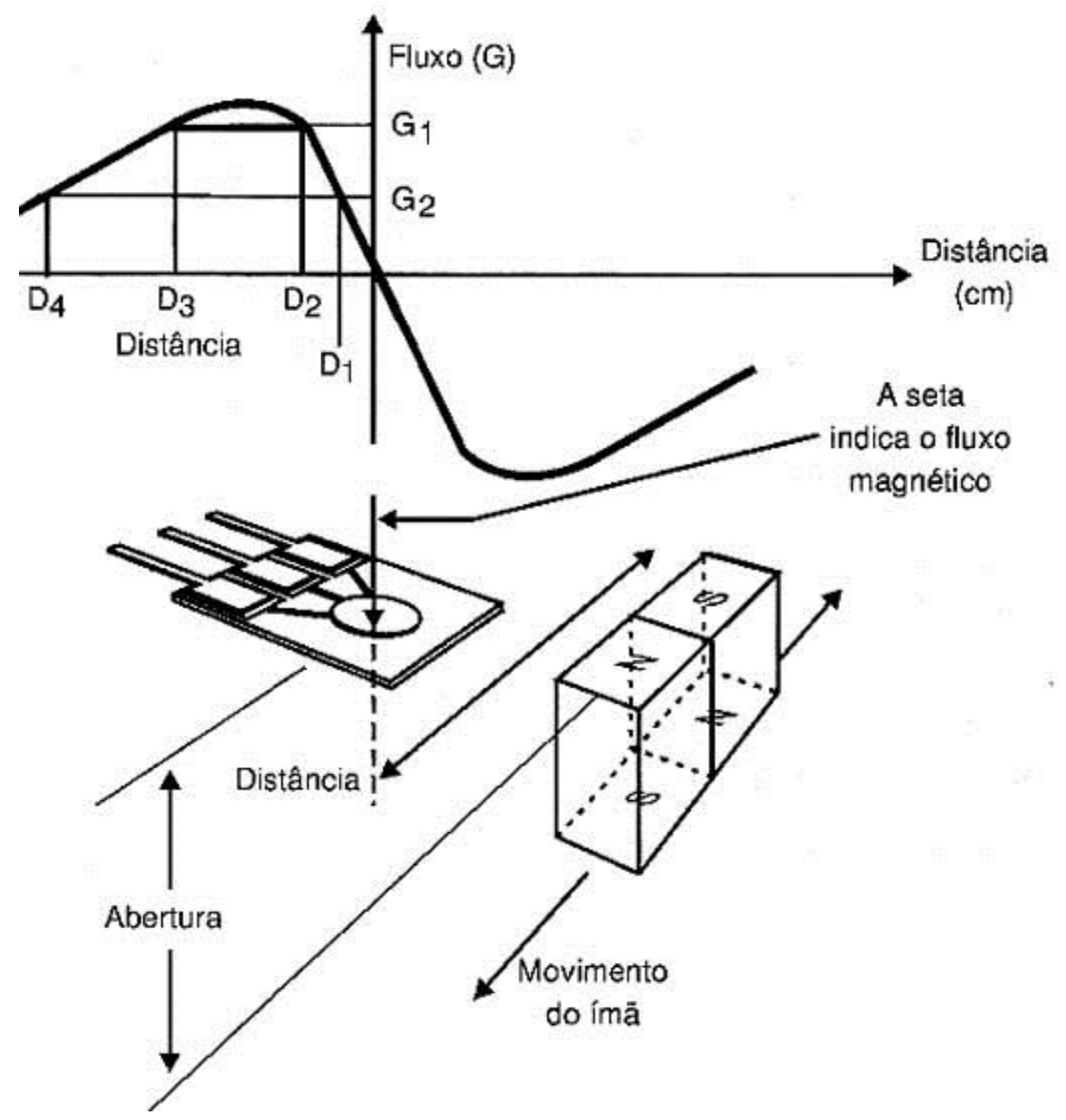

Figura C.3 - Sensor de Efeito Hall - Passagem Lateral Bipolar Fonte: Instituto Newton C. Braga

Utilização de um Sensor de Efeito Hall com a configuração por passagem lateral bipolar e o gráfico que mostra a variação do campo magnético sobre o sensor. 


\section{Passagem lateral tripolar}

Nesta configuração, três imãs são colocados juntos, (formando um imã "tripolar") de modo a gerar um campo no sensor quando passar lateralmente por este. Este arranjo permite detectar com alta sensibilidade a passagem de um objeto diante do sensor. O sinal de saída á agudo o suficiente para excitar com facilidade circuitos lógicos amplificados, devido ao pico de magnetização. Este arranjo pode ser utilizado para medir a velocidade com a qual um objeto passa pelo sensor (como sua rotação, por exemplo) ou ainda para fazer a contagem de objetos que passam pelo sensor.

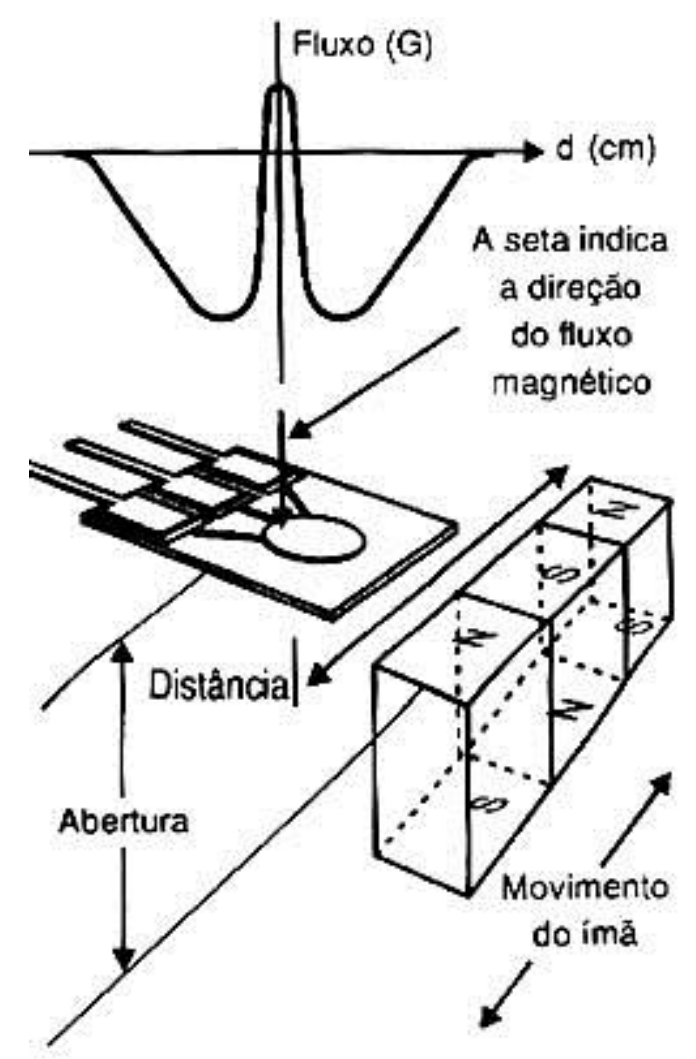

Figura C.4 - Sensor de Efeito Hall - Passagem Lateral Tripolar Fonte: Instituto Newton C. Braga

Utilização de um Sensor de Efeito Hall com a configuração por passagem lateral tripolar e o gráfico que mostra a variação do campo magnético sobre o sensor. 


\section{Passagem lateral com dois imãs separados}

Neste arranjo são utilizados dois imãs. A forma do sinal obtido é suave e a distância de separação entre os dois imãs é que determina os picos. Este tipo de arranjo e utilizado em muitos sensores de distância vendidos comercialmente.

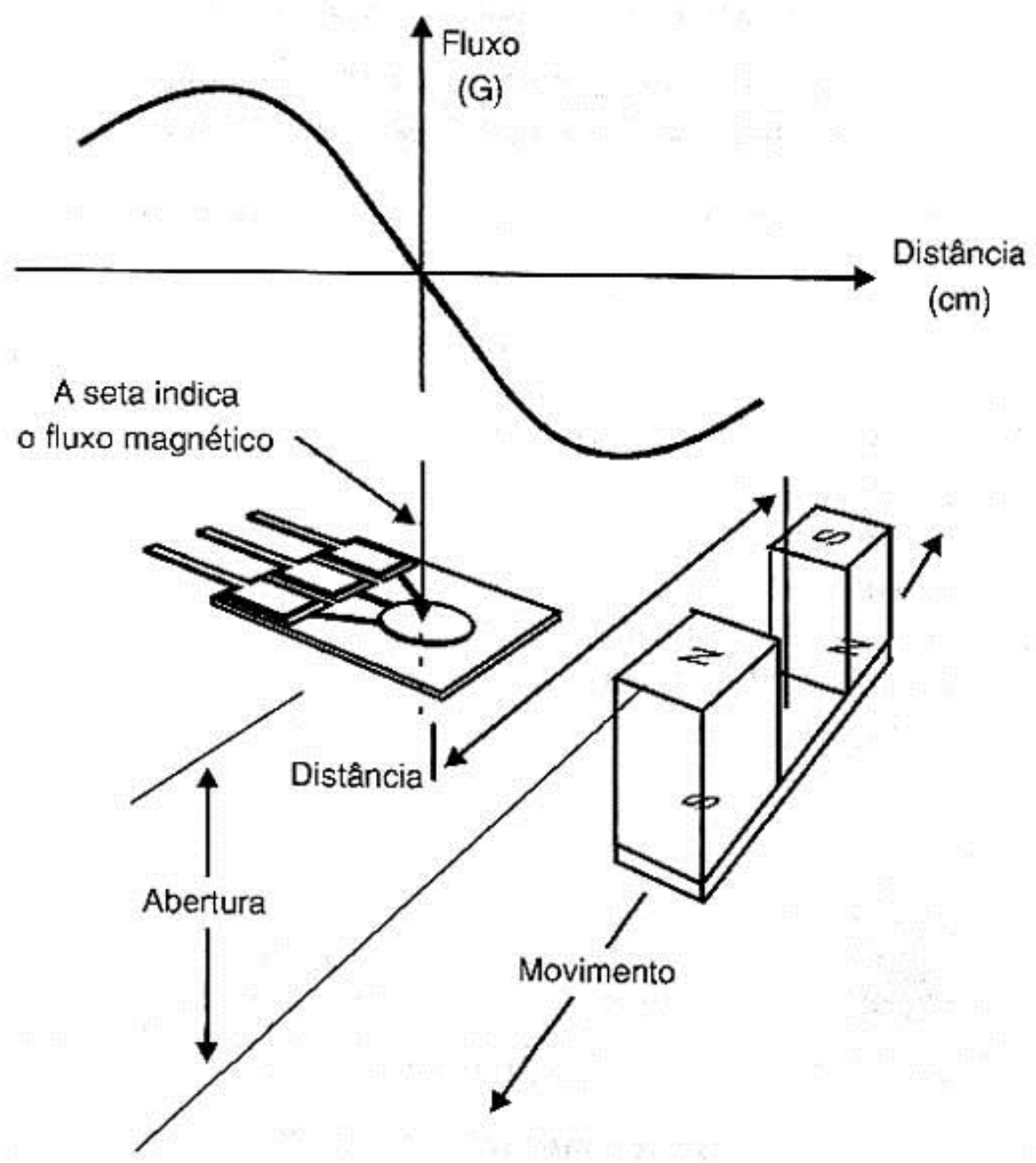

Figura C.5 - Sensor de Efeito Hall - Passagem Lateral com dois imãs separados Fonte: Instituto Newton C. Braga 
Utilização de um Sensor de Efeito Hall com a configuração por passagem lateral com dois imãs separados e o gráfico que mostra a variação do campo magnético sobre o sensor.

\section{Imã rotativo}

Este arranjo permite detectar movimentos de rotação com facilidade. Aqui, um imã circular (ou imãs presos a uma peça circular) pode ser utilizado, de modo a gerar o mesmo padrão de campo. O sinal gerado com este arranjo é senoidal e pode ser facilmente trabalhado para excitar circuitos lógicos.

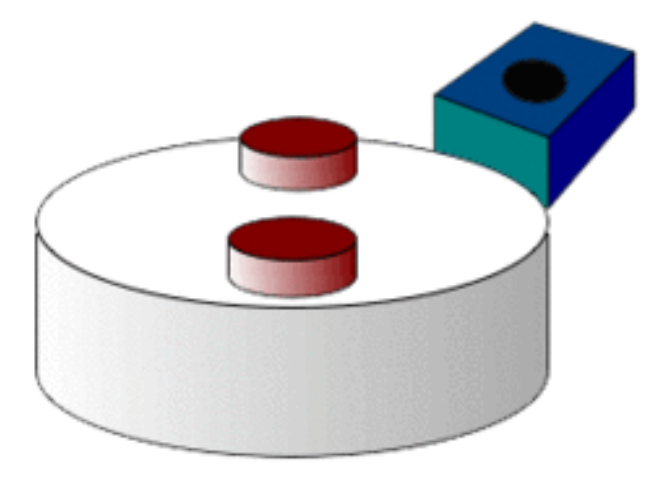

Figura C.6 - Exemplo de Arranjo com Imã Rotativo Fonte: Instituto Newton C. Braga

Exemplo de configuração com ímã rotativo. Este arranjo é comumente utilizada para regular a velocidade de discos rígidos de computador. Temos um disco rotante com dois ímãs igualmente espaçados. A tensão oriunda do sensor Hall irá ter seu pico duas vezes a cada revolução do disco. 


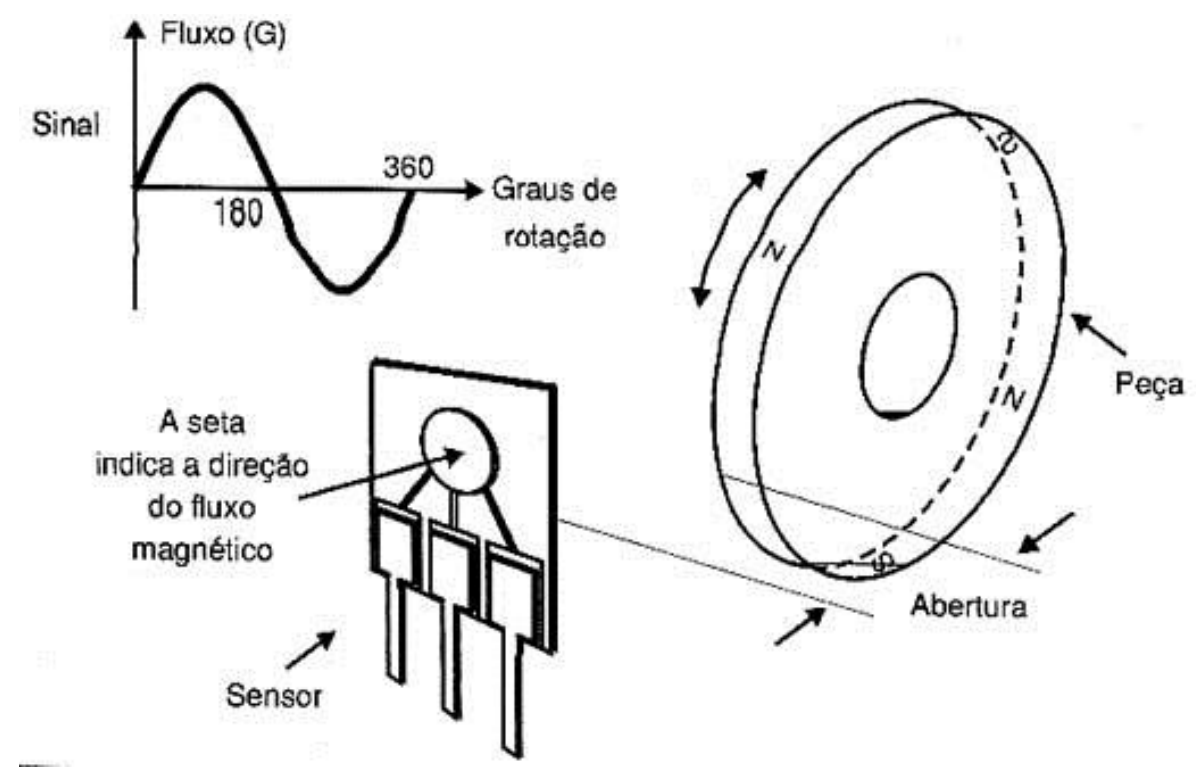

Figura C.7 - Sensor de Efeito Hall - Configuração por Imã Rotativo Fonte: Instituto Newton C. Braga

Utilização de um Sensor de Efeito Hall com a configuração por imã rotativo e o gráfico que mostra a variação do campo magnético sobre o sensor.

\section{Outros arranjos}

Outros arranjos, além dos apresentados, podem ser construídos de acordo com a necessidade do projetista, isto é, irão da orientação das linhas do campo que deve detectado, além sua variação e intensidade.

As curvas de sensibilidade em reação a posição devem ser levadas em consideração quando se utiliza um Sensor Hall. O próprio formato do sensor pode incluir recursos no sentido de contentar ou dispersar linhas de força. 


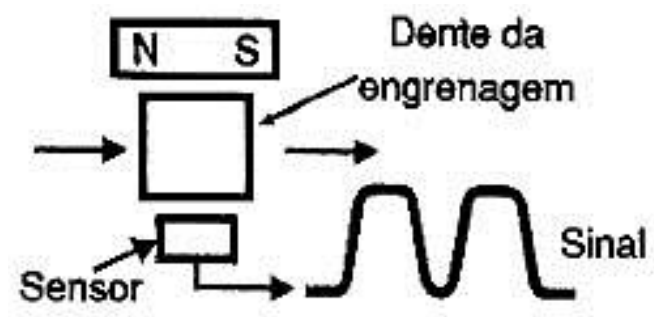

Figura C.8 - Sensor de Efeito Hall -Arranjo com Imã Fixo Fonte: Instituto Newton C. Braga

Um exemplo aplicação de arranjo com imã fixo no qual a passagem de um dente de uma engrenagem de um material ferromagnético entre um Sensor Hall e um imã permanente concentra as linhas de força do campo, gerando um pulso de sinal.

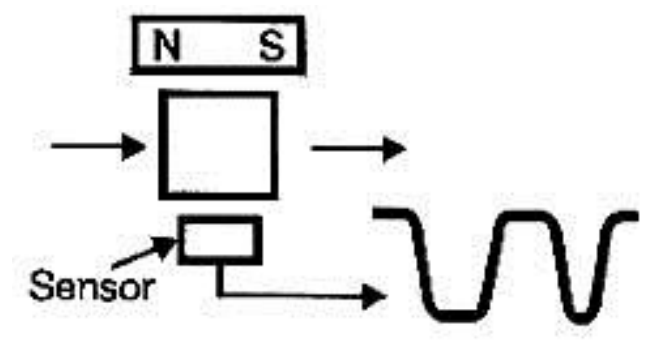

Figura C.9 - Sensor de Efeito Hall - Arranjo com Imã Fixo Fonte: Instituto Newton C. Braga

Um exemplo aplicação de arranjo com imã fixo no qual a passagem de um dente de uma engrenagem de um material diamagnético (como alumínio, por exemplo) entre um Sensor Hall e um imã permanente dispersa as linhas de força do campo magnético, gerando um efeito inverso ao observado em materiais magnéticos.

\section{Aplicações}

$\mathrm{Na}$ sua forma mais simples, o sensor Hall funciona como um transdutor analógico que retorna diretamente um valor de tensão. Com um campo magnético conhecido, pode-se determinar sua distância até a placa Hall. Usando um grupo de sensores, pode-se deduzir a posição relativa do ímã. 
A eletricidade transmitida por um condutor irá produzir um campo magnético que varia com a corrente. É possível utilizar um sensor Hall medir esta corrente sem interromper o circuito.

Frequentemente, um sensor de efeito Hall é combinado com um circuito que permite que o dispositivo possa atuar em modo digital (liga/desliga). Nesta configuração, o sensor Hall funciona como interruptor (ou chave).

Comumente vistos em aplicações industriais, tais como o Cilindro Pneumático, os Sensores de Efeito Hall também são utilizados em itens de consumo. Em algumas impressoras, por exemplo, o sensor Hall é utilizado para detectar o papel ausente em tampas abertas. Quando é necessária uma alta confiabilidade, o sensor Hall também é utilizado em teclados.

Os Sensores Hall são também comumente usados no setor automobilístico para medir a velocidade de rodas e eixos, calcular o tempo de ignição de motores de combustão interna, além do uso em tacômetros e sistemas de Freio ABS. Eles são utilizados, por exemplo, para detectar a posição do ímã permanente em motores elétricos de corrente contínua sem escovas.

\section{Sonda Hall}

Uma Sonda Hall contém um cristal composto de Índio semicondutor, como o antimoneto de índio, montado em uma placa de apoio de alumínio e encapsulado na cabeça de sonda.

A Sonda Hall é posicionada de forma que as linhas do campo magnético passem ângulos retos com o sensor da sonda. Assim, o medidor lê do valor da densidade 
de fluxo magnético. Uma corrente é passada através do cristal que, quando sob a aplicação de campo magnético, adquire uma diferença de potencial de Efeito Hall. O Efeito Hall é observado quando um condutor é colocado sob um campo magnético uniforme. O desvio natural dos elétrons portadores de carga faz com que o campo magnético exerça a Força de Lorentz sob estes portadores. O resultado é o mesmo observado para uma separação de cargas, com acumulação de cargas positivas ou negativas no fundo ou na parte superior da placa. $\mathrm{O}$ cristal deve ter em torno de $5 \mathrm{~mm}^{2}$. O cabo da sonda deve ser de material não-condutor, de modo a não perturbar o campo magnético.

A Sonda Hall pode ser utilizada para medir o Campo Magnético da Terra. Para tal, as linhas de campo da Terra devem estar passando diretamente através da sonda. Em seguida, ela é girada rapidamente, de modo que as linhas do campo passem através dos sensores na direção oposta. A alteração na leitura de densidade de fluxo é o dobro da densidade de fluxo magnético da Terra. Uma sonda Hall deve ser, primeiramente, calibrada com relação a um valor de força do campo magnético conhecido. No caso de um solenóide, coloca-se a sonda Hall no centro do mesmo.

\section{Sensor de Deslocamento}

Um Sensor de Deslocamento pode ser feito com um elemento sensor de efeito Hall e um ímã móvel, obtendo-se um valor de saída proporcional à distância entre os dois. Dois ímãs podem ser posicionados com um sensor Hall, a fim de que se obtenha uma intensidade de campo próximo a zero quando o sensor estiver equidistante dos dois ímãs. Este dispositivo de efeito Hall possui um alcance linear bastante limitado, contudo maiores alcances podem ser obtidos ao se utilizar múltiplos sensores Hall, distribuídos ao longo de um substrato. À medida que o ímã se aproxima e, em seguida, se afasta de 
cada elemento Hall, os respectivos sensores estarão aumentando ou diminuindo os valores de saída.

O valor de saída do conjunto de sensores é obtido por meio da leitura e decodificação das saídas individuais dos sensores mais próximos ao ímã. Este método permite produzir sensores de deslocamento com um desempenho relativamente alto, capaz de ter um alcance de vários metros. Sensores de alcance mais longo tornam-se cada vez mais difíceis de produzir e são caros devido ao grande número de sensores que precisam ser multiplexados.

\section{Indicador de Nível de Combustível}

O Sensor Hall pode ser utilizado em alguns automóveis em indicadores de nível de combustível. Isso é feio por meio de um flutuador magnético ou de um sensor de alavanca rotativa.

Em um sistema flutuante vertical, um ímã permanente é montado sobre a superfície de um objeto flutuante. O condutor de alimentação de corrente elétrica é fixado na parte superior do tanque de alinhamento com o ímã. Quando o nível de combustível eleva, um campo magnético crescente é aplicado na corrente, resultando em uma alta voltagem Hall. À medida que o nível de combustível diminui, a tensão Hall também diminuirá. O nível de combustível é indicado e exibido pela condição adequada de sinal da tensão Hall.

Em um sensor de alavanca rotativa, um ímã em forma de anel diametralmente magnetizado gira em torno de um Sensor Hall linear. O sensor mede apenas a componente perpendicular (vertical) do campo. A intensidade do campo medido está 
diretamente correlacionada com o ângulo da alavanca e, assim, com o nível do tanque de combustível.

\section{Outras Aplicações}

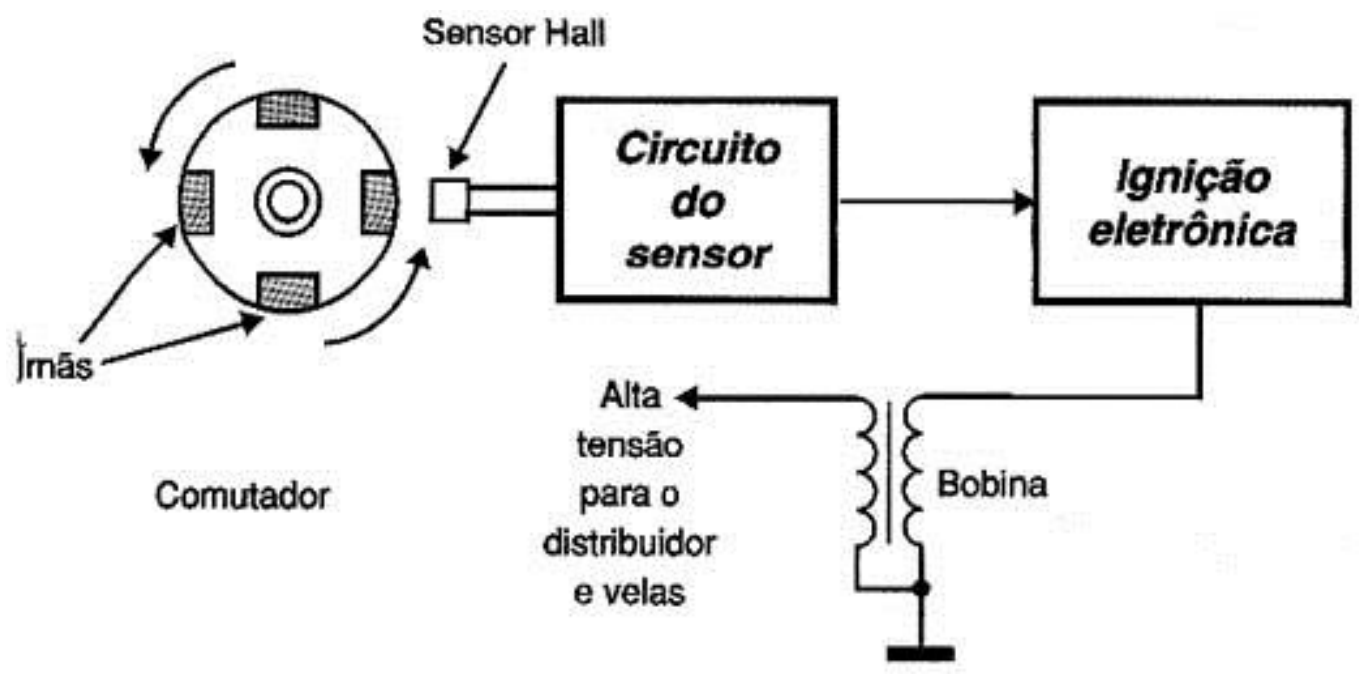

Figura C.10 - Exemplo de Aplicação na Ignição Automotiva Fonte: Instituto Newton C. Braga

Circuito sem contatos, substituindo o platinado. Num carro, por exemplo, um sensor magnético mede com precisão a rotação do motor fazendo o acionamento das velas.

Usando sensor para medir a rotação de uma polia de uma máquina. Numa máquina industrial um sensor magnético preso a uma engrenagem permite medir com precisão rotação e controlá-la com a ajuda de circuitos eletrônicos externos. 


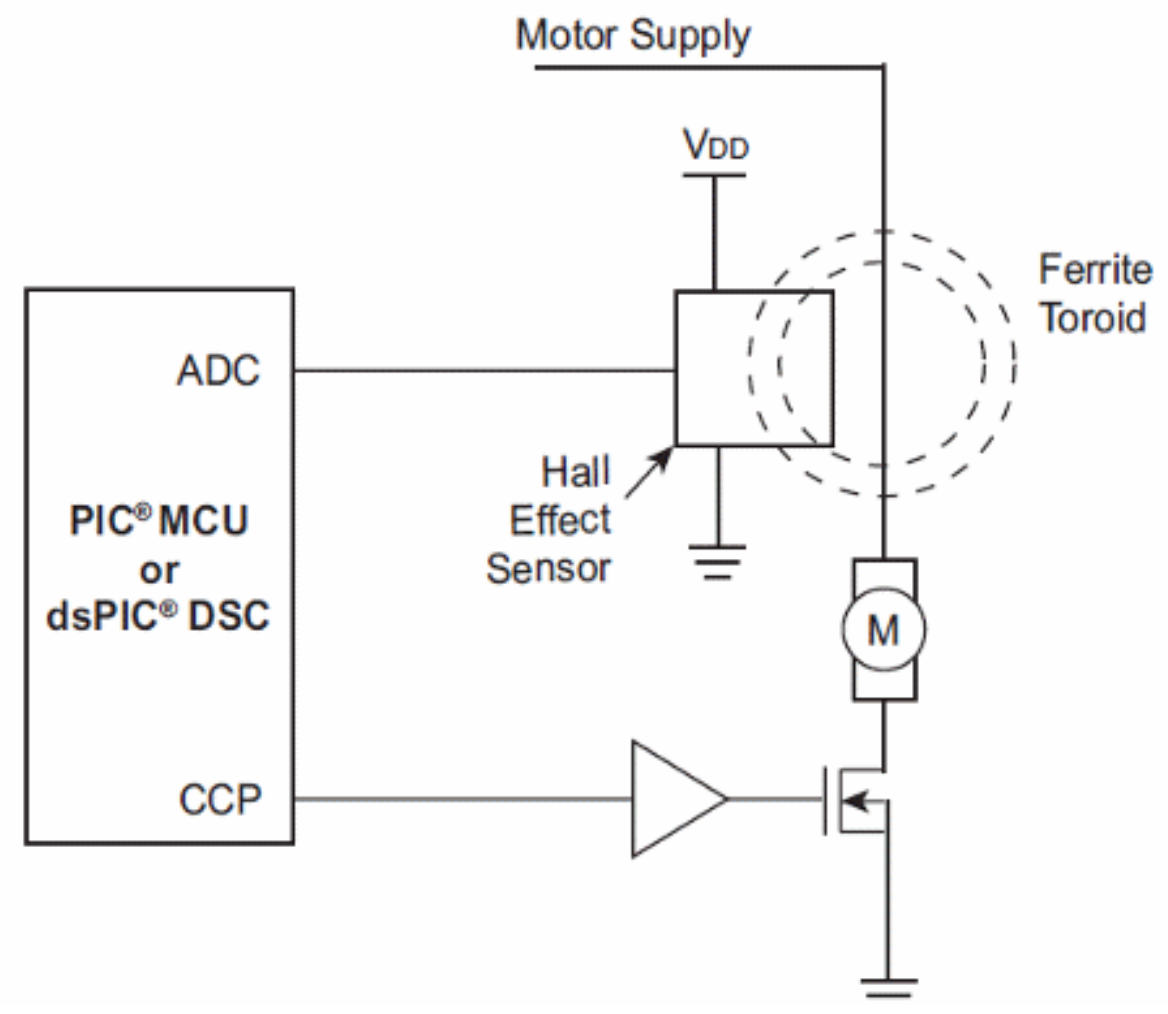

Figura C.11 - Sensoriamento Magnético de Corrente Fonte: Instituto Newton C. Braga

Um sensor Hall pode ser usado para sensoriar a corrente de um motor num sistema de controle. O sensor é posicionado num anel de Ferrite e o elo de corrente do motor pode ser formado por uma ou mais espiras no toróide de ferrite conforme a intensidade da corrente a ser sensoriada. 


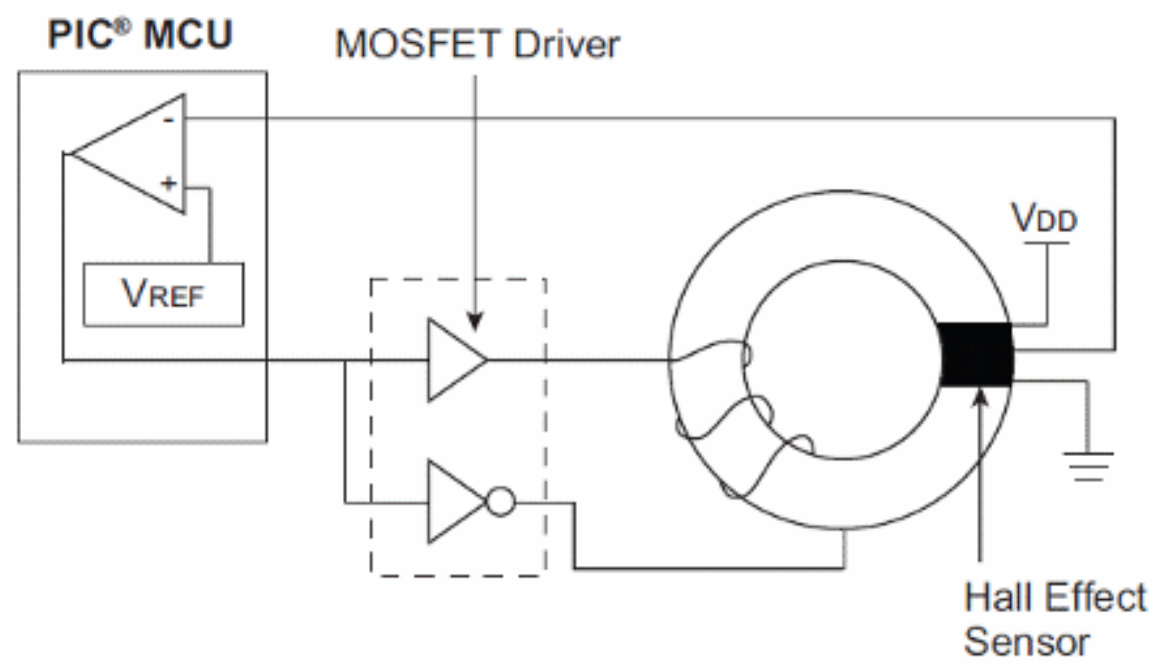

Figura C.12 - Sensor Hall de Corrente com PIC Fonte: Instituto Newton C. Braga

O circuito é especialmente indicado para a medida de correntes intensas. Quando a corrente é zero, a tensão no sensor será Vdd/2. O circuito é bidirecional, podendo medir correntes nos dois sentidos. Os comparadores são usados para gerar uma corrente no núcleo de modo a obter um fluxo contrário ao da corrente medida. Este recurso tem por finalidade obter maior linearidade na medida, mantendo o fluxo no ferrite nulo. 